\title{
上顎齒槽突起及ビ上顎竇底ノレ線學的 並二病理組織學的研笢（第二報）
}

Dr. Saburo Tsunooka : Röntgenologische und patho-histologische Untersuchungen uber die Beziehungen zwischen dem Alveolarfortsatz und der Oberkieferhöhle. (II. Mitteiluug).

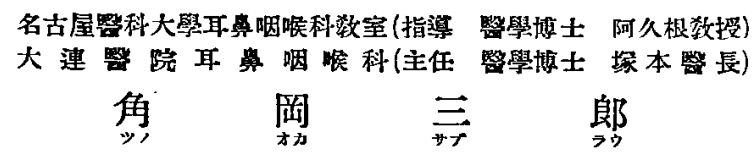

(本論文翣旨、昭和 12 年 6 月 27 日第 35 回大日本 $)$

目

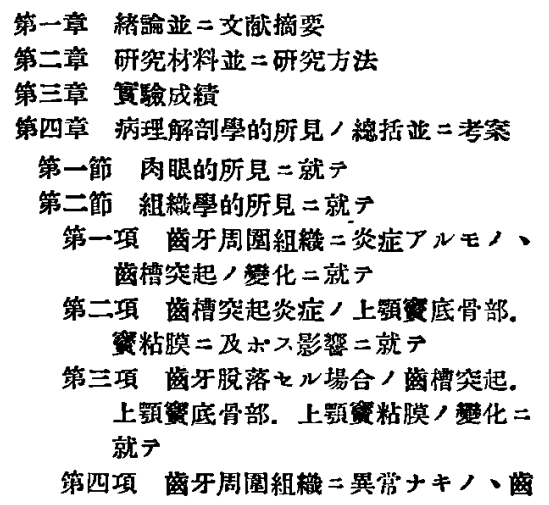

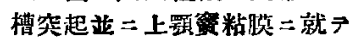

次

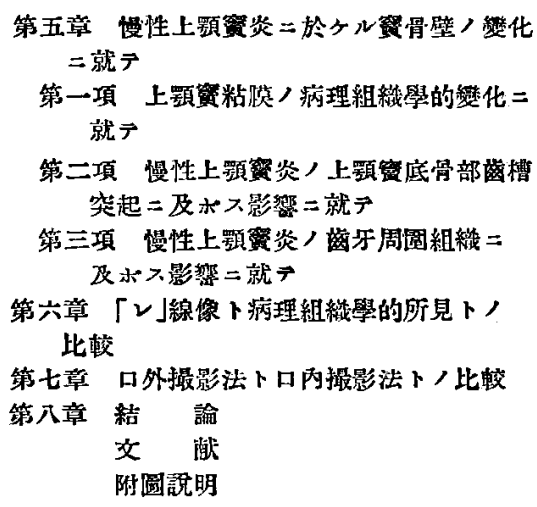

\section{第 一 章}

\section{緒論㫫二交献摘要}

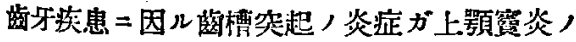
登生二對シ密接ナル關係习有スルコトハ, 古柬 幾多ノ先丠諸學者/注意セル處ニシテ.之二關 スル研究藻靕乏夥シキ數二上レリ。特二上影覆

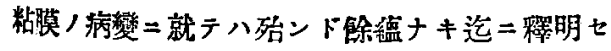

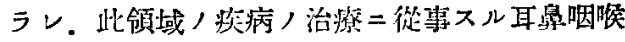

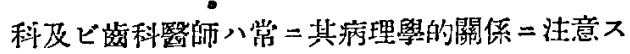
ルトコロナリ。

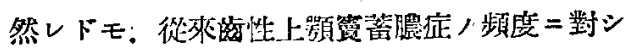
テハ、多數學者ノ經䮑區タニシテ其述ブルトコ 


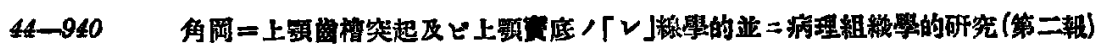

ロ一致セズ。皆テ八、上顎赛蓄膿应ノ總テノ場

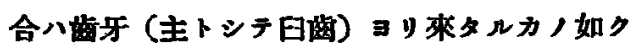

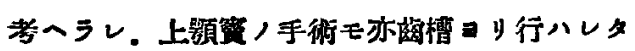
ル時代フリシ八周知ノ事寅ナルモ。其後/文献

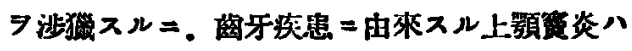

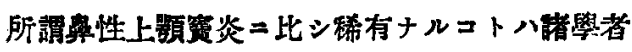

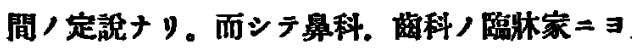
ル報告二於テ八．頻度比較的多シトセラレ，反 之. 解剖學者 $=ヨ$ ル報告ニ於テハ. 甚夕橁有ナ リトセラル。臨朋家方面 $コ$ 其統計 7 見ル 稳科二於テハ鼻科二比シ其頻度大ナりト主㖘七

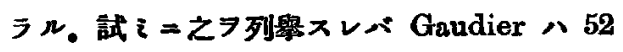
例二於 $=13.3 \%$ 。荻野氏八 81 例中約 $8.7 \%$ 。 Wasowski. 八 112 例=於 テ $10.0 \%$. Hinsberg ト Kallisch 八全留察例/ 5.0\%. Tonndorf $\sim 5.0 \%$. Hirsch $\sim 10.0 \%$. Berberich 八10.0-15.0\%. Skillern $~ 20.0 \%$. Lermo-

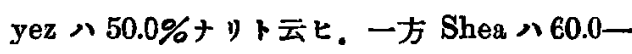
80.0\%. Hove 八 25.0\%+リトモ云七。其他 Partsch, Reinmoller, Mejerhofer 等/齿科諸

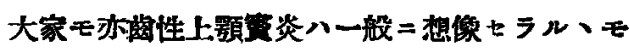
ノョコ。其頻度造カ二大ナルコトヨ述ベタリ。 然ル，解剖學者八其頻度価少ナル Dmochowski 八 152 例/屁體/中. 1例モ之 尹見ズト云ヒ. Zuckerkandl(1893) 八300 例

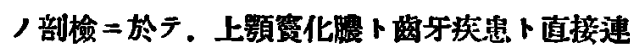
絡フルモノ1例ノi 7 見タリト云ヒ. Harke (1895) E. Fränkel(1896) モ亦. 剖检/紹 果 Zuckerkandl ト同荄谌ダ稀有ナルコトラ確

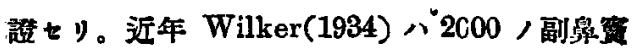
炎人統計的覞察习行へル $=$. 肉眼的 $=$ 齿牙 $\exists y$ 發來セル上顎筑炎ナルコト明確ナルモノ八篗力 $=5$ 例, $\boldsymbol{i}+リ$.

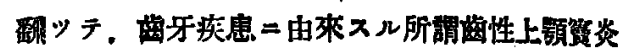

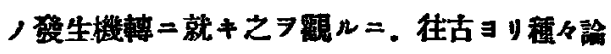

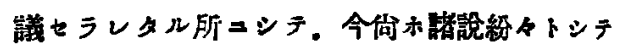

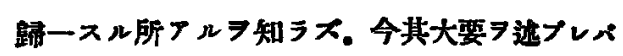
Hajek (1909) 八梅慒突起，急性炎症タルト慢

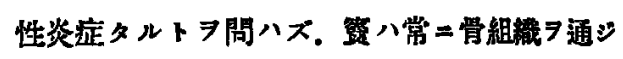
テ感染スルモノナリト云と. Tilley八䆓 感热 八淋巴管刃八血管习通ジテ起ルカ。或八此牙二

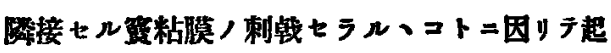
ルモノナリト云と. Killian (1892) ト Zarnilo （1894）ハ神經並＝血管腔ヨ通ジテ起ルモノナリ ト云へリ.Strubell (1c01) 八上頻管粘膜/深居 郎チ骨膜厔二存スル毛細管網。上顎骨游綿質内 =フル粗大網及ビ断慒及ビ齿根膜細網トハ互二 極メテ密接ナル結合ヨナシ。故=炎证/蒙延”

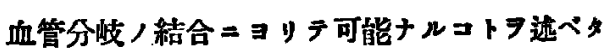
门。我が國=於テモ，大正 2 年久保(猪)氏八丵

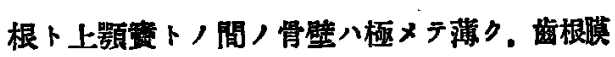
卜上顎窟粘膜卜，血管，間 =八. 多数/吻合丁 リテ相通ズルガ故二。 之二因りテ病變八容易二 上下=移行シ得ルモノナリト速ー゙リ。昭和11

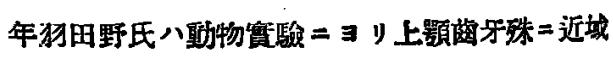
，日齿二於テ八，上颚震卜或程度，淋巴路/速

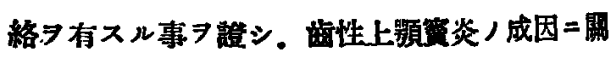
シ. 淋巴路 $=\Xi ル$ 轉位感染，可能ナル

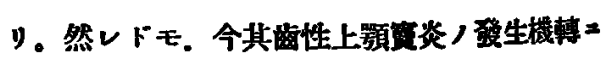

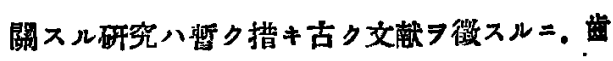

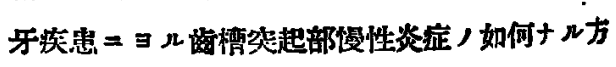
法. 如何ナル狀態ノモト二上䫘宽 = 感染スルモ ノナリヤ ヘルモノ甚ダ室タタリ。

Weski(1921) 八屍體上影二於テ、「レ線像卜

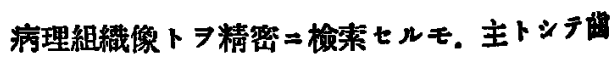




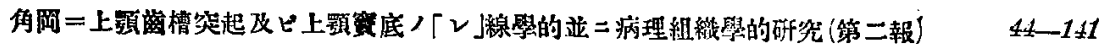

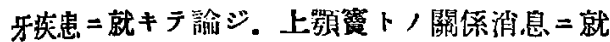
キテハ論及セズ。唯ダ二三症例 =於テ，骨炎症 ノ筫二進行波及セルラ確認セルノえ。

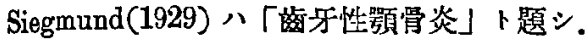

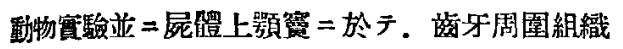

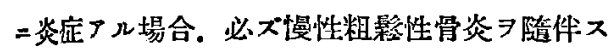
ルモノナリト逃へ。其他顎骨，病變二就キ，微 ニ入リ細ニ亘り速ブルトコロアリテ. 佃々 =就 キテハ。骨炎ノ筧二進行スル組織像 ルモ。骨炎ト上顎瓄卜，關係消息二就キ記载ス ル所ナシ。

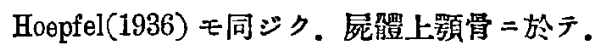
病理組織學的檢索

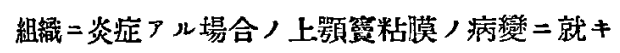

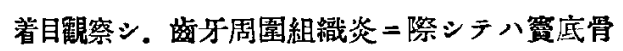

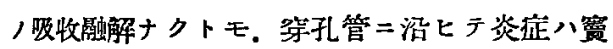
ニ波及スルコトアルタ證セリ。

之等八皆. 歯標突起 =炎症アル場合，上顎簤， 變化二就キ諭ジタルモ。.之 炎定 $几$ 場合.上顎齿標突起並 $=$ 齿牙 $=$ 變化 7 及ボスコト八容易二想像サル、所ナルモ．此際

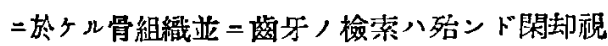
サレタル觀ノリ。唯ダ僅カニ Manasse (1922), Nühsmann(1926), Berberich(1932) 等之二就

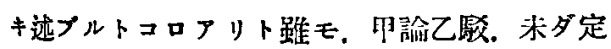
說アルヨ知ラズ。

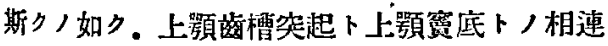
關七几病理組織學的關係二就キテハ. 更二研究 ヨ要スベキ事項ヨ多ク遗セル八. 臨桨上. 上顎

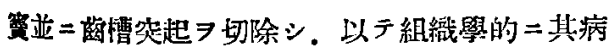
理习检装スルコトノ咴ンド不可能ナルコトニ原 因スト云フヨ得べシ。

一方. 覱近「レ」線學，長足，進步卜其二，近

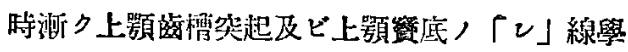
的检查ヨ行フモノアレドモ。此部「レ」線像制 讀二就テハ．末多解決サレザル墨極メテ多ク． 特二上顎签底部二於ヶル「レ」線像二就テ八詳

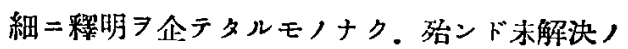
狀態ニアリ。之余が本研究 7 企胃シタル所以= シテ. 先二第 1 報 (大日本耳鼻咽喉科會會報第

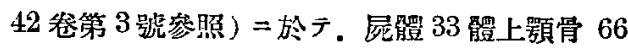

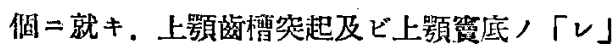
線學的檢少 $フ$ 口外並 $=$ 口内撮影法 $=\exists リ$ 施行 ル成續 組織學的檢索习遂ゲタルラ以テ. 先=述べタル 「レ」線學的研究ト，比較對照 7 行七。佾ホ口 外鼬影法卜口内撮影法卜，異同然=言及シ。相 互，關係 $フ$ 稍 タルラ以テ.えヲ發表シ。大方諸賢ノ御批制 仰ガントス。

\section{第二童}

\section{研究材料並二研究方法}

研究材料。本研究第 1 報二用ヒタルモノト同 シ。

研究方法。標本部位八第 1 報二述べタル「レ」 線像に相當スル部位フ摆ベリ。

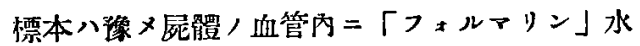
溶液 7 注大シテ尼觛全部 影藏シタル材料ヨリ上顎骨 7 切除シ.之ヨ今村， 华稳氏）賞用シタルiェルレル氏液（重「クロ ーム」酸加里 2.5. 硫酸「ナトリウム」1.0. 水

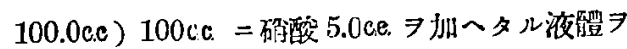
以于脫灰シタリ。即于最初 1 週間八每日脫灰液 7 替人. 第 2 週八 2 日曻 $=1$ 回交撸\%. 此間二

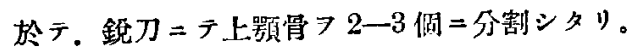




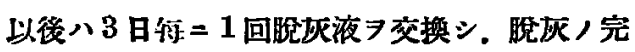
全ナル 7 俟チ，10日間充分二水洗シ，挠 $70 \%$ 「アルコホール」ニテ4 日間. $80 \%$ 「アルコホ

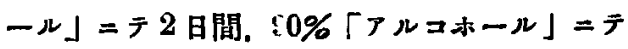
3 日間. 然水「アルコホール」=テ 3 日間脫水 シ. 次イデ「ッェロイジン」包埋フ施シデ組織 切片习作成シ.「ヘマトキシリンエオジン」染色 法フ行ヒテ检浆に供セり。

組䄉切片八全部賛舌面/方向二切リ，可及的大

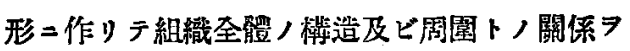
明瞭二研素シ得儿溙努メタリ。

\section{第三完 \\ 實 驗 成 績}

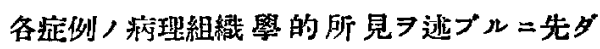

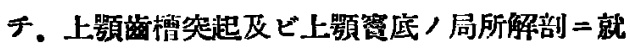
キ。特二洼目七几淘位二就手說明习机へン。

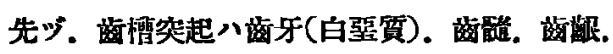

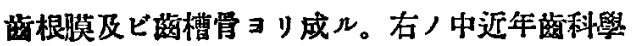

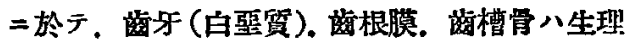
的二モ解剖學的二モ發生學的二モ單一的ノモノ

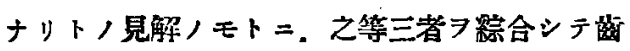
牙周園組識 (Paradentium, Parodontium) ル名稃タ以テ現ハサル、ニ至レリ。郎チ所謂邀

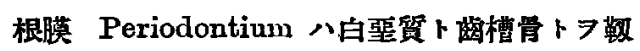
带連合ヨ以テ結合スルモノンシテ. 此間 =八血

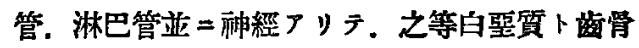

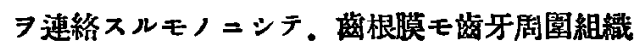
ノ一部二屬ス。從ツテ落根膜=炎症了ル場合八

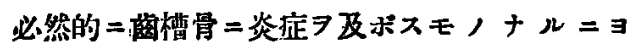

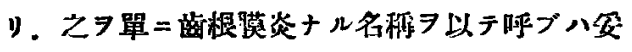
篦ナラズトナスモノナリ。

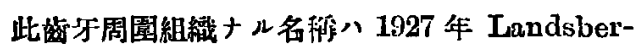

ger, Weski /管メテ唱运セシトコロニシテ.

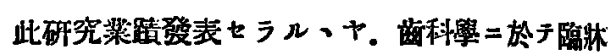

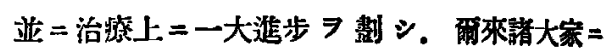
ヨリテモ盛二賞用セラル、二至レリ。余モ亦 Landsberger ト Weski / 說=倣七. 获牙(白

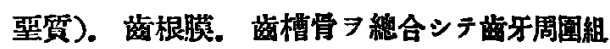
織ト呼べリ。

從ソテ. 此部 =於テ炎症性變化アルモノ ヨ齿牙

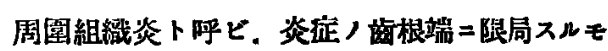

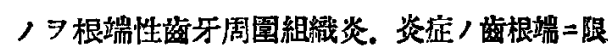
周セズシテ。齿根膜全體ニ亘りテ存スルモノョ

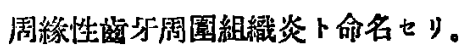

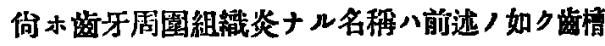
骨々炎ノ存在スルコトラ意味スルモノナレド

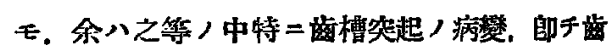

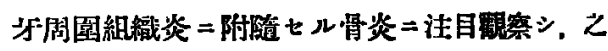

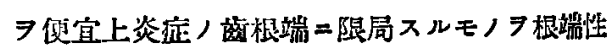

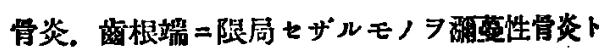
命名七り。

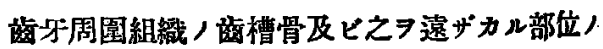
离槽骨ハ多數ノ網狀シナセル骨梁フリテ. 其間

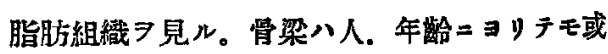
八部位ニヨリテモ其太サシ異ニスルモノナレド

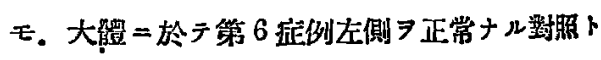
シテ他ノモノト比較シ：骨梁ノ粗トナりテ細り

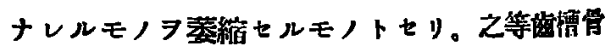

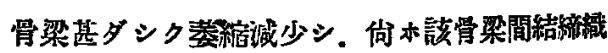
垻殖七ルモノ 7 病理組織學上維維性骨炎卜命名 七リ。

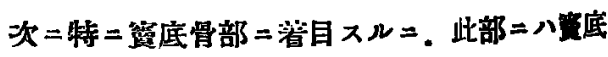

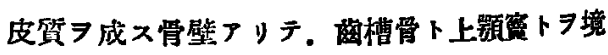

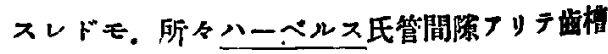

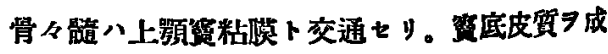


ス骨壁ハ郎チ網狀シナセル海綿買骨梁，上㴚二 シテ，他ノ骨梁トョク區別サル、場合アリ。或 八他ノ管梁ト相交錯シ區別劃然タラザルモノア

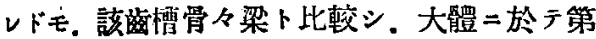

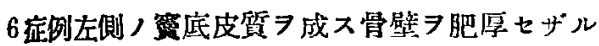
モノ、對照トシ。肥厚セルモノト肥厚セザルモ ノト二區別七り。佾木其外骨賭殖機轉（造骨細 胞) /有無习检七り。

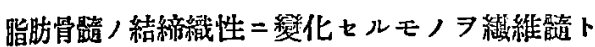
呼稱七り。

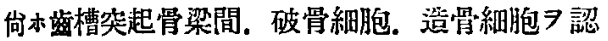
ムルモノアリ。之等著明二認ムルモノラ記載 シ。著明ナラザルモハハ之省格セリ。

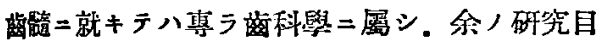

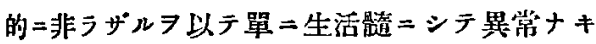
モノト。壤死二陷レルモノト二區別シ。詳細=

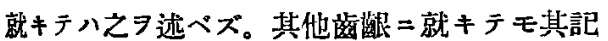
淢习省略セり。

次二上顎簤底粘膜八骨膜. 上皮下組織。上皮。組 械二大别七ラル。管粘膜二異常ナキモノ八，例 之第 6 症例左側ノ如ク骨膜へ他部二比シ結䋨織 蟣維稍：密ナリ。

上皮下組織モ一般ニ極メテ彭租ナ几結締織ヨリ 成リ．腺八分岐セル管狀葡萄狀細胞腺ニシテ。 其周圍 $=モ$ 炎症性變化 $\exists$ 認メズ。又腺腔ノ擴大 セルモノナシ。

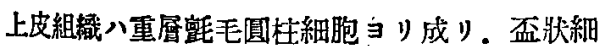
胞习含ム。

郎千. 第 6 症例左側 7 上顎靁底粘膜ノ異常ナキ モノ、對照トシ。炎症性變化 キテハ之ョ骨膜.上皮下組織。上皮組織, 各層 ニ分チテ之ア記载セり。

細胞浸潤八淋巴球.「ブラスア」紬胞.「エオジ
ン」嘴好細胞。組織球等アレドモ。等 二圓形細胞卜記耕倒シ。以テ多核白血球浸潤卜區 别七リ。

答症例/病理組織學的所見ハ次/如シ。

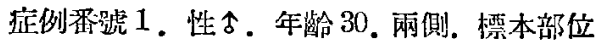
第 2 大臼苳。

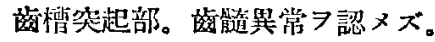

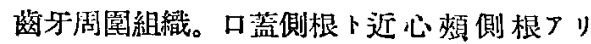
テ. 全落牙周園組織二炎症性變化 認メズ。之 ヨ遠ザカル部位ニ於テモ異常ナシ。骨梁八全般 ニ亘リテ瑟縮セズ。

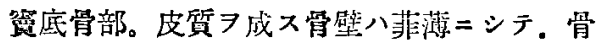

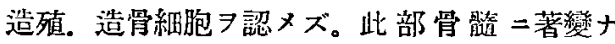

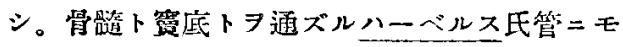
異裳ナシ。

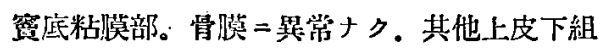
織。上皮組織二炎症性變化

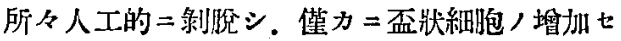
$ル \ni$ 見ル。

病理組織學的診斷。兩側共異常ナシ。

症例番號 2 . 性占。年落 34 . 兩側。標本部位 第 1 大的莮。

萄慒突起部。齿䯕異常 齿牙周園組織。口蓝側根卜近心頓侧根厂》

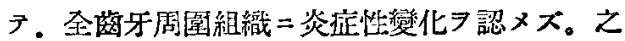
ヨ遠ザカル部位ニ於テモ異裳ナシ。骨梁八全娟 二亘り羲縮セズ。

㬅底骨部。皮質习战ス骨壁八肥厚增殖シ所々 造骨細胞アリ。此部位二於ケル骨䯕ニハ異常ナ

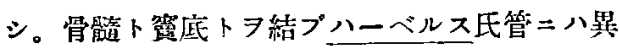
常ナシ。

窑底粘膜部。骨膜二八綿䋨䋨塯殖七ルモ。細 胞浸潤ナシ。上皮下組織ハ浮腫貼二肥厚シ。全 
體ニ亘りテ軴度ノ圆形細胞ノ浸潤ノリ。上皮組

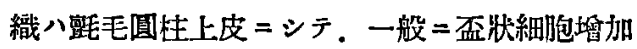
ス。所々人工的 $=$ 剩脆 ス。

病理組織學的診斷。慢性上影霓炎.

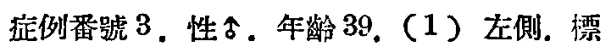
本部位、第 2 大臼薮。

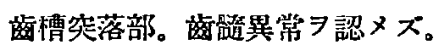

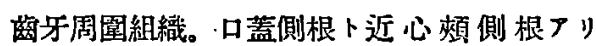
テ. 全落牙周圍組緎=炎症性變化 ヨ遠ザカル部位二於テモ異常ナシ。骨梁八全體 ニ亘りテ萎縮セズ。

蜜底骨部。皮睤 $ᄏ$ 成ス骨壁二骨堆殖，造骨 細胞ナク，一般二菲薄ナリ。此部骨䯕二著變

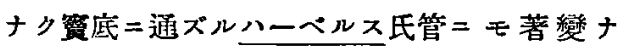
シ。

箩底粘膜部。炎柾性變化 病理組織學的診断。異常ナシ。

(2) 右側. 標本部位. 第 2 小臼齿。 齿槽然起部。啮随八標本二現ハレズ。 齿牙周图組織，口蓋側根及ビ湢側根アリテ。

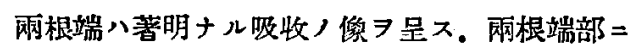
多核白血球，圆形細胞ノ浸㵎アリテ。肉芽組織 ア形成シ。上皮帶ナシ。肉芽組織/周圍八緻密

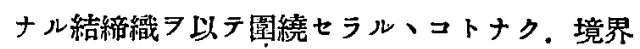
不明二周圈骨梁間 =移行ス。周園骨梁八吸收》 レ.其間偩形細枹ノ浸潤アリテ骨梁=波及スレ

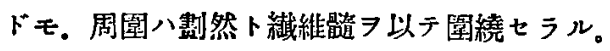
細胞浸潤八血管周園二著明ナレドモ覀底二波及

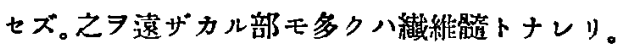

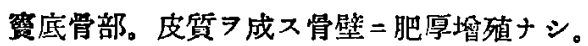

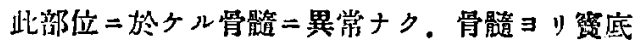
二通ズルハーベルス氏管ニモ基常す認メズ。 琵底粘膜部。骨膜八結締織增殖スレドモ。細
胞浸潤ナシ。上皮下組織へ主トシテ圆形細胞ノ 浸潤厂リ。腺組織增殖シ腺管稘层シ。其間圆形 細胞ノ浸潤强シ。上皮組織八罡毛圆柱細胞二シ テ. 盃狀細胞增加ス。所々人工的二剩㧤ス。 病理組織學的㻅斷。慢性根端性跑牙周園組織 炎。慢性根端性骨炎。慢性上影察炎。

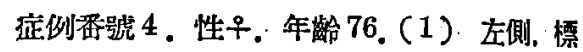
本部位. 低崡上頡ニシテ。大日齿二該當スル部 位。

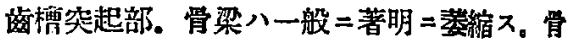
體/大部分八脂肪細胞习以テ充タサレ。骨梁間 二炎症性變化 7 認 $\times ス 。$

䍃底骨部。皮質 $ᄏ$ 成又骨壁=盵厚增殖，造骨 細胞ナシ。此部位ニ於ケル管膸二著變ナり所タ 算底二通ズルハーベルス氏管フレドモ異常ナ シ。

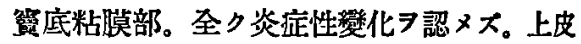
組織八所々人工的二剝脫ス。

病理組糡學的診斷。異常ナシ。

(2) 右側. 標本部位. 焎齿上矤ニシテ.大 曰海 =該當スル部位。

荛槽突起部。骨梁八一般二著明二萎縮ス。骨 梁間 =炎症性變化ナク，大部分八脂肪細胞 7 以 テ充サル。

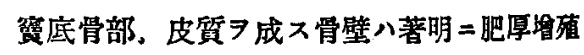

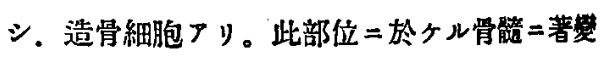

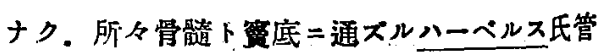
フレドモ異常ナシ。

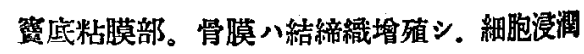
ナシ。上皮下組織八結締織增殖シ浸潤少ン。腺

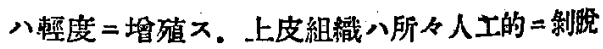
スレドモ。著變ナク倾カ＝盃狀細胞坦加せり。 病理組織學的診微。慢性上顎察炎。 


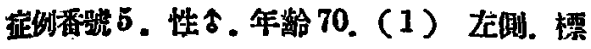
本部位. 第 1 大臼造。

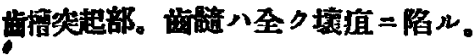

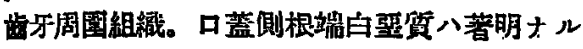

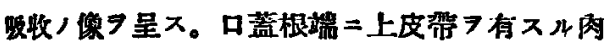

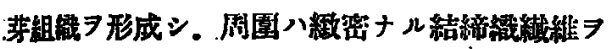
以テ圈繞セラル。該結䋨織織維八著明 $=$ 居狀 ナシテ走。維維間及ビ織維外二主トシテ多核白

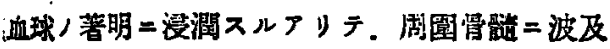
シ. 急性炎症绝 7 示メセリ。多核白血球/浸潤 八血管に沿上テ著明ナレドモ。齿根ト宾底ト，

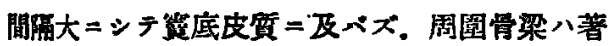

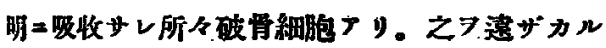

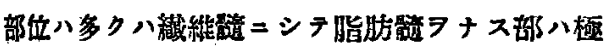
メテ勘シ。

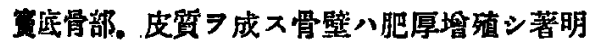

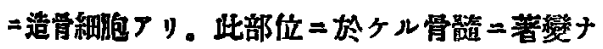

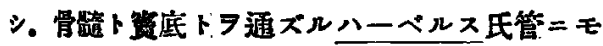

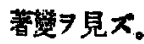

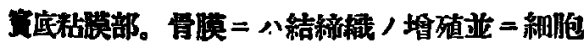
浸渵フリ。上皮下組織八多核白血球，国形綝胞

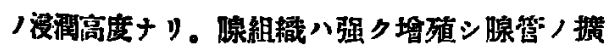

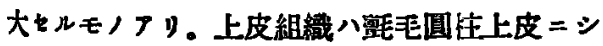
ラ所々人工的二剩䏸シ。盃狀細胞增加セり。

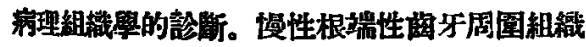
炎（急性）轉㙨ヨトレルモノ），愠性根端性骨 炎。慢性上影需炎 。

（2）右側. 標本部位。無齿上頡ニシテ.略

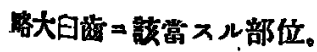

齿澛猋起部。骨梁ハ著シク薮縮ス。骨梁間稍

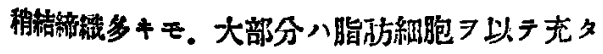

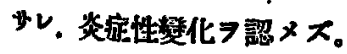

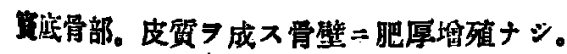

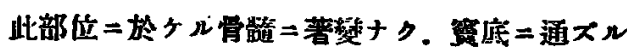
ハーベルス氏捾ニモ異常ナシ。

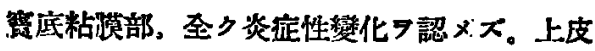
組織へ人工的二全ク制硬セリ。

病理組識學的診断。異常ナシ。

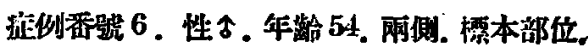
第 2 大臼造。

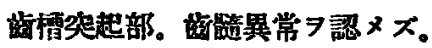

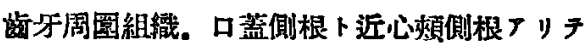

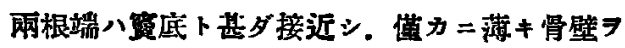
以テ隔テラル。齿牙周圍組織八全㯰ニ亘りテ炎

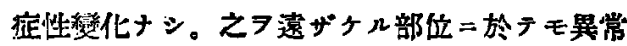
ナシ。骨梁八全體ニ亘リテ萎縮セス。

筼底骨部。皮啠

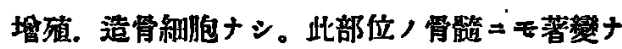

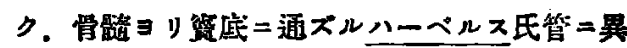
常ク認メズ。

管底粘膜部。骨膜二異常ナ，上，上皮下組織。

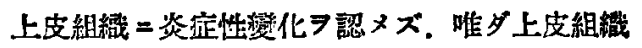
ハ人工的二剢脫シタリ。

病理:組織學的診斷。网側卜气異裳ナシ。 症例番躆 7. 性里。年龄 33. (1) 左側。標 本部位，第 2 大田薂。

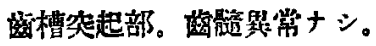

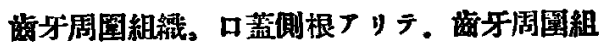

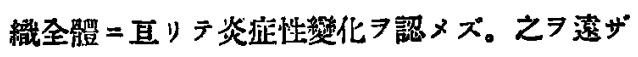
カル部位ニ於テモ暴常ナシ。骨梁ハ全體二亘り テ菜樎セズ。

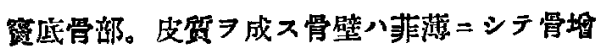

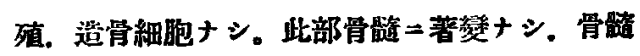

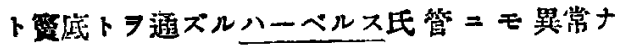
シ.

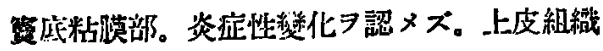


八人工的 $=$ 制脫シ．嚾カ $=$ 甭.狀細胞，垉扣セル 見儿。

病理組繊學的崄断。買常ナシ。

(2) 右側, 標本部位, 第 2 大且嵌。

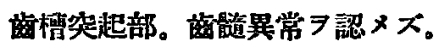

落牙周囼組織。口蓋側根卜近心頓側根トフリ

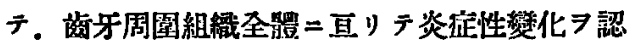
メズ。えマ迬ザカル部位二於テモ巽勞ナシ。骨 梁ハ一般二萎縮セ

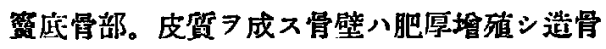

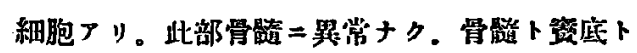
タ通ズルハーペルス氏登ニモ異営ナシ。

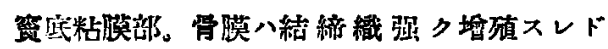

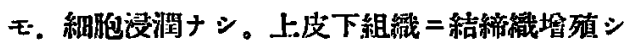

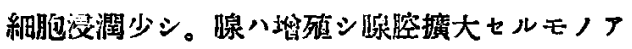
リ。上农組織八壇毛圓柱細胞ニシテ盃狀細胞多 シ。所々人工的二制脫 $ス 。$

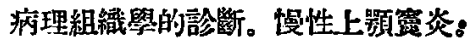

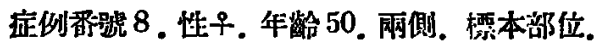
第 2 大臼齿。

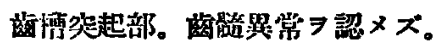

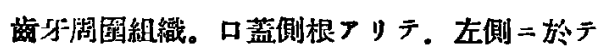
八根端八管队二裸出シ。赛粘膜 7 以テ被覆サ

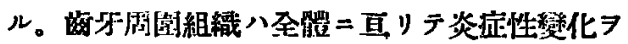

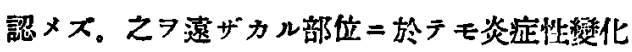
ナシ。骨梁ハー一般=菱縮セズ。

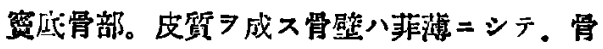
俈殖ナシ。此部位ニ於ケル骨䯕二落變ナク，骨

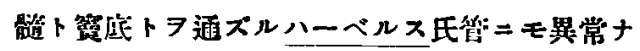
シ。

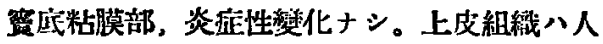
工的二涂脘シ盃狀細胞增加七り。

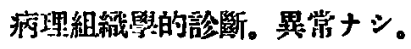

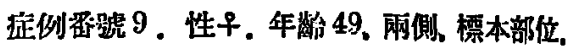

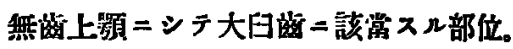

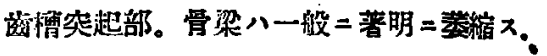
骨髓八脂肪細胞 ア認メス。

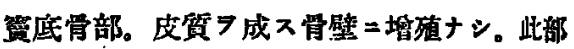

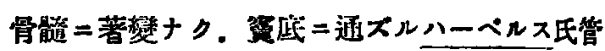
ニモ異常ナシ。

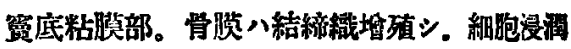
ナシ。上皮下組織八結締織增殖シ漫潤少シ。腺

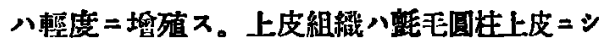
テ. 所々人工的二制㱝盃狀細胞增加七り。 病理組䋨學的猃斷。慢性上顥管炎。

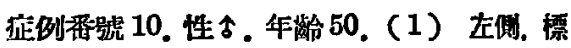

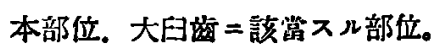

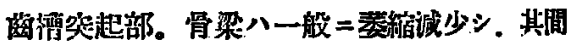

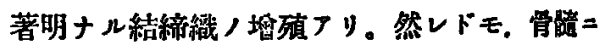
八䍃底骨部

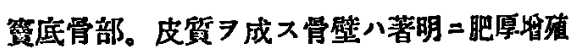
シ所タ二逘骨細胞アリ。此部位二於ケル骨锴ハ

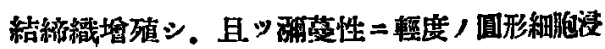

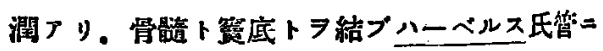
モ游瞢性＝細胞核潤フリ。

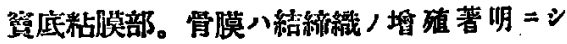
テ. 其間白血球ノ浸潤厂リ。上皮下組擮八白血

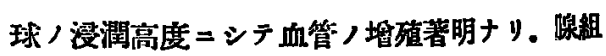
織ハ殆ンド認メラレズ。上皮組織ハ大部分制脫 セリ。盃狀細胞ノ増扣ラ見ル。

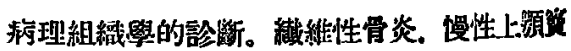
炎。

（2）右側. 標本部位. 第 2 大日齿。

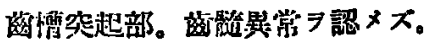
诲牙周圍組織。口蓋側根ト近心煩側根トフリ 


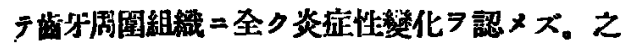

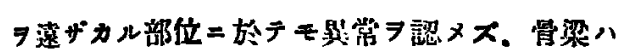

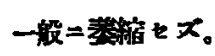

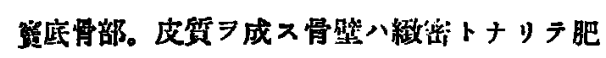
固坮殖シ所々造骨緗胞フリ。此部位二於ケル骨 路二著變ナク：策底二通ズルハーベルス氏管組 諓中ニハ鯰メラレズ。

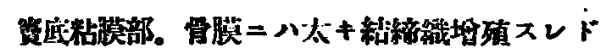
モ. 絧胞浸潤認メラレズ.上皮下組維ハ主トシ

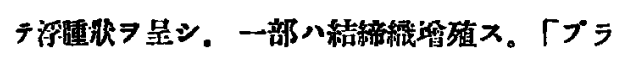

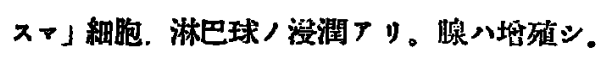

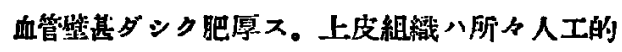

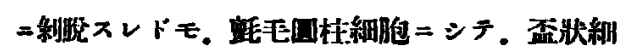
胞塯加

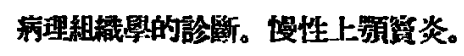

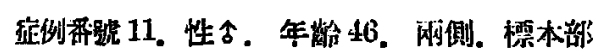
位. 第 2 大日齿。

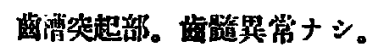

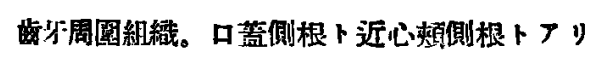

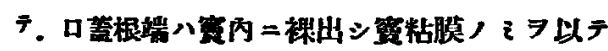

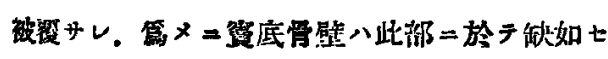

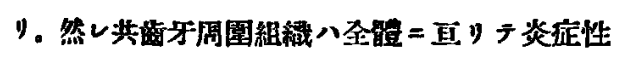

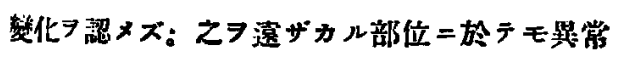

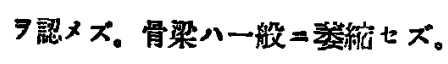

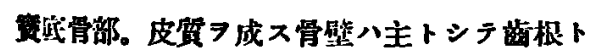

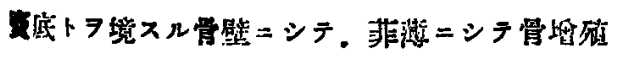

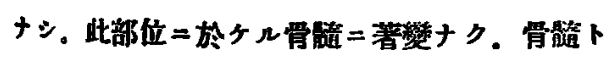

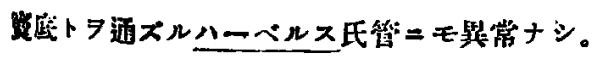

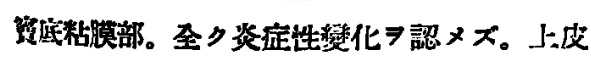

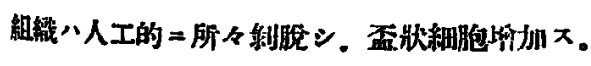

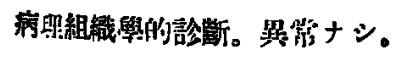

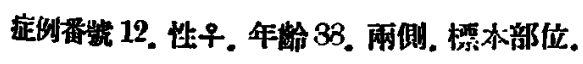

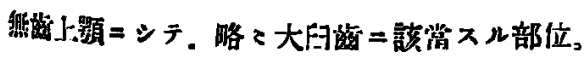

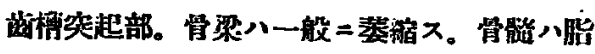
肪細胞

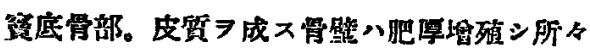

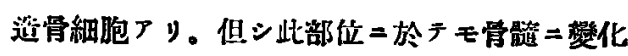

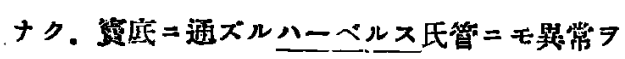
認メス。

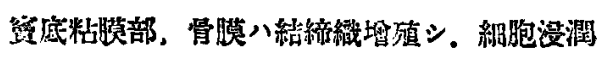
ナシ。上皮下租䧴八浮腫狀

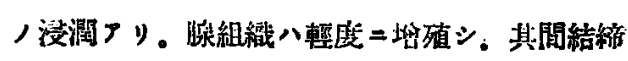

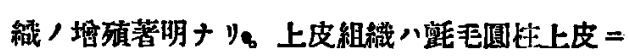

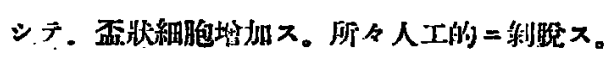

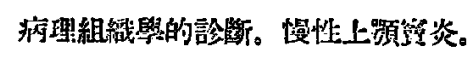

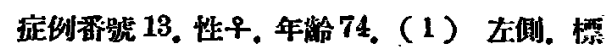
本部位。第 2 大田藏。

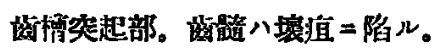

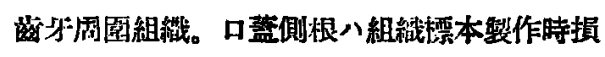

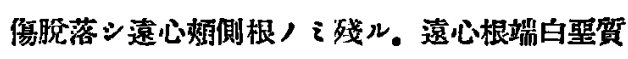

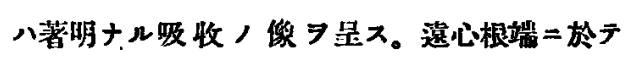

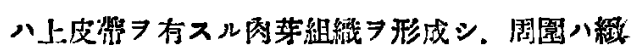

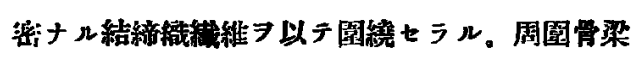
八吸收セラレ. 其間圆形細胞ノ浸㵎フリテ闹图.

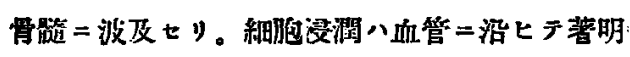

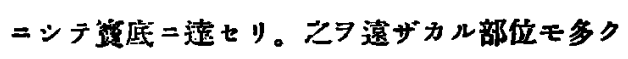
八繊維骼トナレリ。

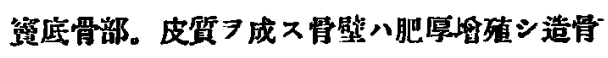

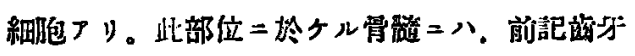

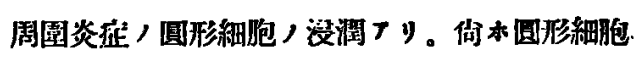

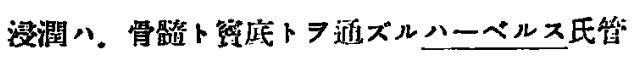

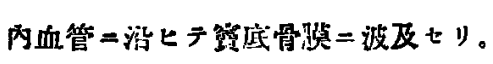

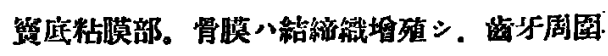

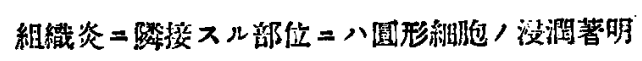
ナリ。上皮下組織へ主トシテ，多核白血球. 固

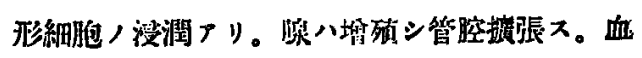




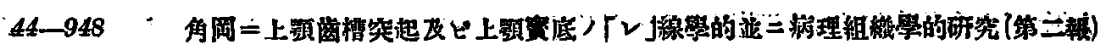

管壁,肥厚著明ナリ。細胞浸潤八四牙ト近接ス ル部ニ於テ著明ナリ。上皮組織八距毛圆柱上度

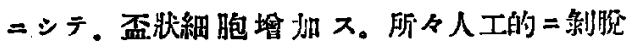
.

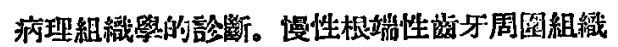

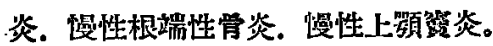

(2) 右側. 標本部位. 第 2 大曰齔。

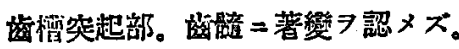

齿牙周圍組織。口蓝側根厂リテ，齿牙周園組 織全但 $=$ 亘り炎症性變化 ル部位ニテモ著變ナシ。骨梁ハ一般二萎縮セ ズ.

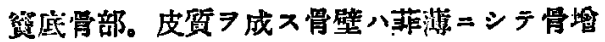

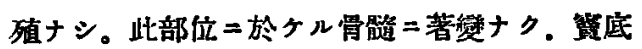
二通ズルハーベルス氏管組織中＝認メラレズ。

惩底粘膜部。骨膜八結䋨織增殖シ。細胞浸潤 フリ。上皮下組織八高度ノ浮嗹 7 呈シ其間 $=$ 白

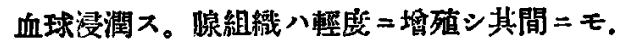
浮尰並 $=$ 細胞浸㵎厂リ，上皮組織。大部分八人 工的二制脫セルモ，㲔毛䁚柱細胞ニシテ盃狀細 胞多シ。

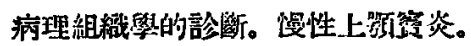

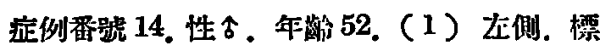
本部位。第 2 大臼蒛。

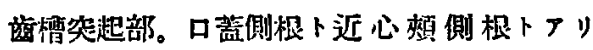

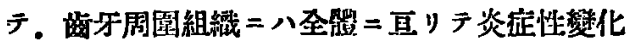
ナシ。之ア遠ザカル部位二於テモ罢学ナシ。骨 梁ハ一般二姿縮セ

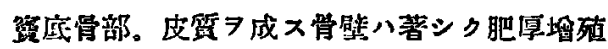

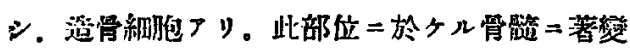

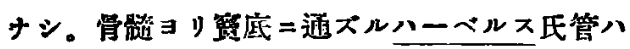
組糡中ニハ認メラレズ。

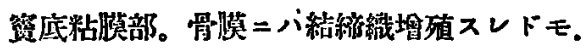

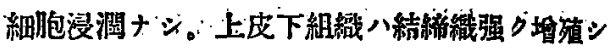

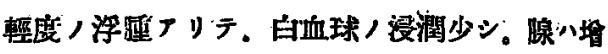

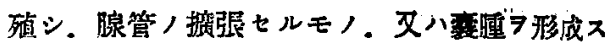

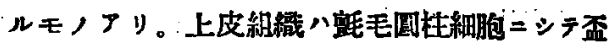
爿細胞多之。所々人工的二剩㧤不。

病理組維學的詮斷。慢性上顎管炎。

（2）古㑡. 標本部位. 第 1 大曰齿。

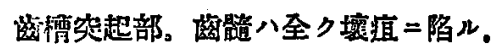

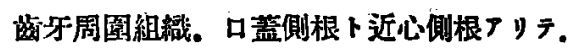
兩根端白晋質八著明二吸收サル。雨根端＝肉茅

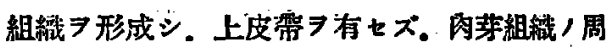

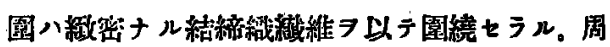
園骨梁八吸收サレ。其間圆形細狍, 浸潤厂リ

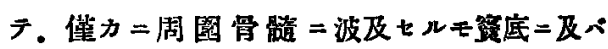

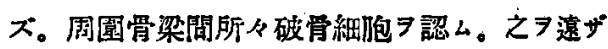

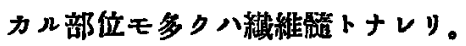

罄底骨部。皮質 $习$ 成ス骨壁八肥厚增殖シ造骨

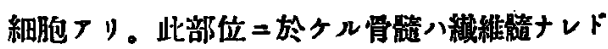

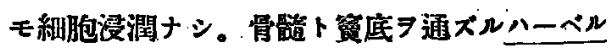
ス氏管:三巽常 7 認メズ。

盗底粘膜部。骨膜二結䋨識增殖えレド細胞 浸潤ナシ。上皮下組織ハ浮遇シ主トシテ。其閒

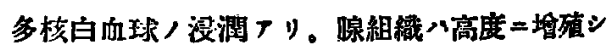

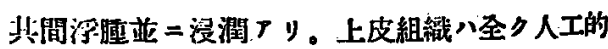
二剩脫七り。

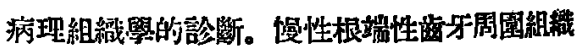
炎. 慢性根端性骨炎. 慢性上顎算炎。

症例僠號 15. 性古。年蒢 68 ，雨側。標本部 位. 热齿上颗

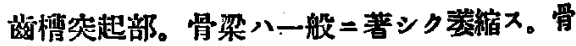

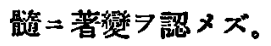

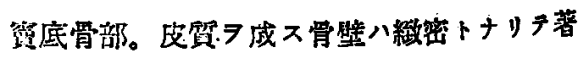
明二肥厚堵殖シ。所今沿骨細胞アリ。但シ此部 


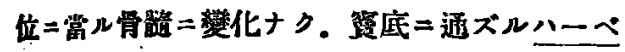
ルス氏管ニモ巽常ヨ認メズ。

顀底粘膜部。骨膜ハ太キ結䋨轼增殖シ其間白 血球少シク浸潤ス。上皮下組織ハ深尰 浸阔著シカラズ、腺八著明二堌殖シ。此部二於

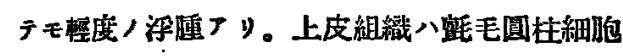
シシテ. 盃狀細胞多シ。所々人工的二剩㬵

\section{y.}

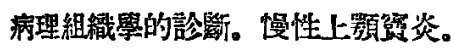
征例番號 16. 性今. 年龄 64. 兩側。標本部位。

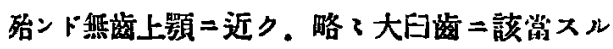
部位。

断槽突起部。骨梁ハ一般二著シク萎縮ス。骨

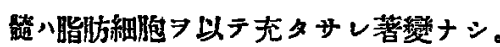

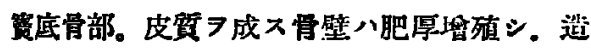
骨細胞厂リ。但シ此部位ニ於テモ骨髓二變化ナ ク.筧底二通スルハーベルス氏管=モ異常 $x x$ 。

货底粘膜部。骨膜八結締織强り堖殖シ肥厚ス レトモ。絴胞浸潤ナシ。上皮下組織ニハ結䋨織

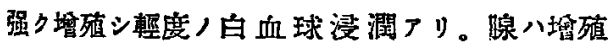
ス. 上皮組樴八悉り人工的二剩挩セり。 病理組䌿學的診断。慢性上顎管炎。 定例番號 17. 性子。年龄 56.（1）左側，標

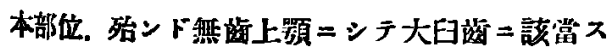
几部位。

齔霄突起部。骨梁ハ一般=萎縮诚少シ，其閒

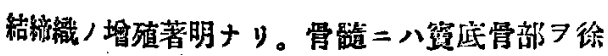
キ。緗胞浸潤

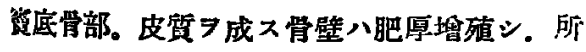
所造骨細胞习認ム。此部骨䯘二モ結 締織 增

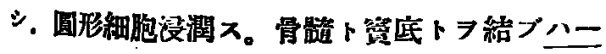

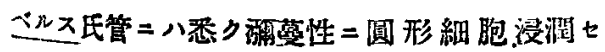

y.

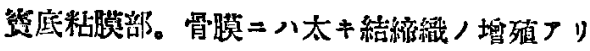
テ. 其間多核白血球ノ浸潤厂リ。上皮下組織八

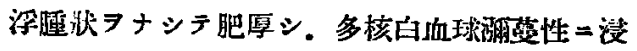
潤セリ。腺組織 垑殖認メラレズ。上皮組織八

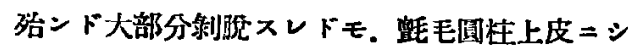
テ盃狀細胞篔加 ス。

病理組織學的診斷。繊維性骨炎. 愠性上影䨘 炎。

（2）右側. 標本部位, 第 1 大臼站。

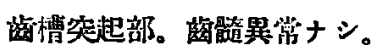

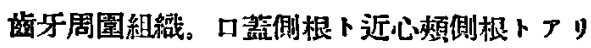

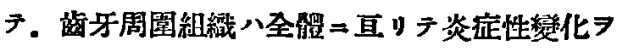
認メズ。えヨ遈ザカル部位ニテモ異常テシ。骨 梁ハ一般二萎縮セズ。

㾞底骨部。皮翼习成ス骨壁八著シク肥厚增殖 シ。所々造骨細胞 7 認ム。此部位二於ケル骨䯕 二著變ナク，筧底二通ズルハーペルス氏管ハ組 織中ニハ認メラレズ。

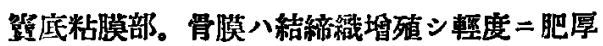
ス。細胞浸润ナシ。上皮下組織八浮隀

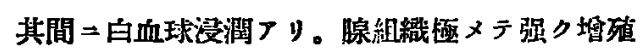

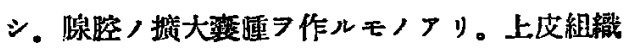
八所々人工的二剩脫スレド. 氈毛圆柱上皮= シテ細胞浸潤ス。盃狀細胞增加ス。

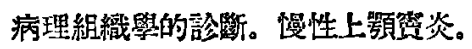
应例番號 18. 性早. 年龄 56.（1）右側。 標本部位. 第 2 大臼荀。

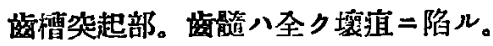

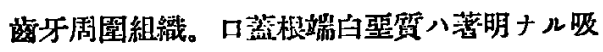

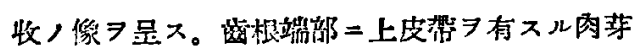

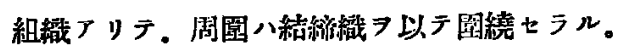

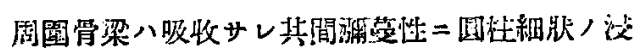




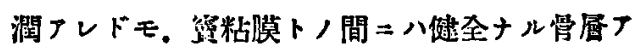
リテ。骨炎ト筑ト，間二面接ノ連絡フ諧セズ。

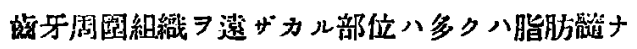
リ。

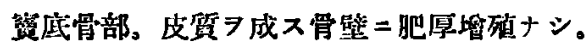

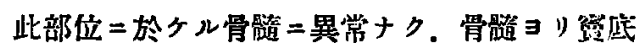
=通ズルハーペルス氏管ニ富メドモ翼常ナシ。

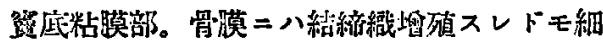

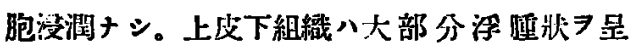
シ。一部八反ッテ結滴䄉, 㙁殖 7 見。一般二桱

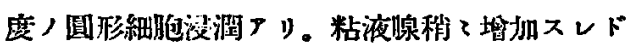

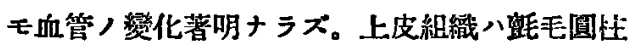

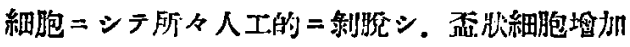

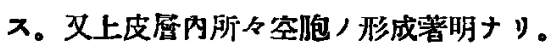

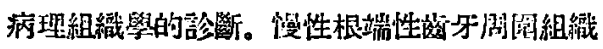

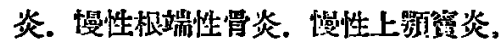

（2）右側。標本部位，第 2 大臼綮。

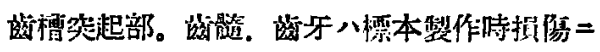
ヨリ悉ク脫落シタルラ以テ不詳ナリ。

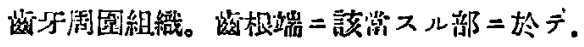

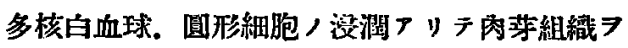

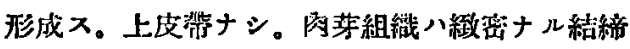
織

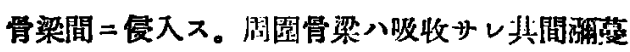
性二多核白血球ノ浸潤つり。細胞浸㵎八血管"二 沿ヒテ進行シ筧底骨壁二逹ス。所々破骨細胞

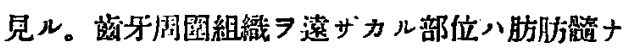
リ。

管氐盛部。皮質 7 成ス骨壁二肥厚垉殖ナシ。

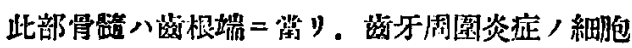

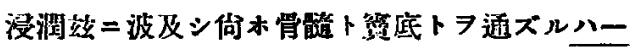

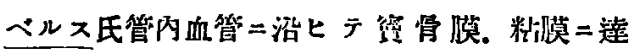
ㅈ.

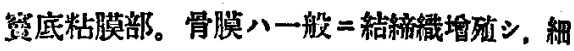

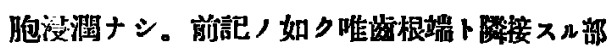

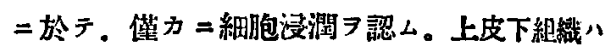

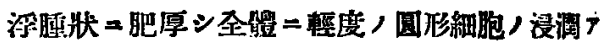

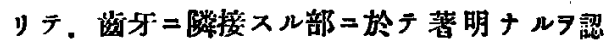
ム。娞組織八堽殖シ腺管八著明二撗張ス。所々 圆形細胞浸閵 / 集積厂リ。上皮入大部分制脑シ

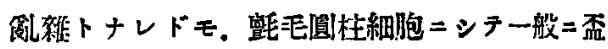
欺細胞䏅加

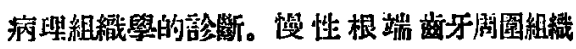
炎。慢性根端性骨炎。慢性上罰瓷炎。

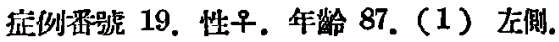

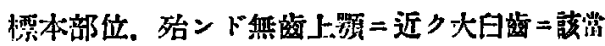
スル部位。

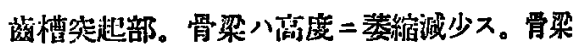
間二八結絃織ノ燴殖著明ナリ。但シ細胞浸㵎》 見ズ。

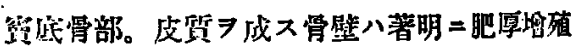
シ所々造骨細胞フリ。骨睤殖シ所々骨膜肥厚組

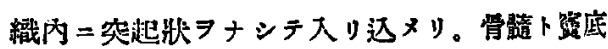
トア絬ブハーベルス氏管結䋨增殖フレドモ細胞 浸润ナシ。

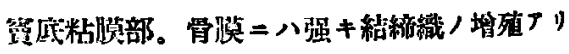
テ肥厚スレドモ。細胞浸潤ナシ。上皮下組織”

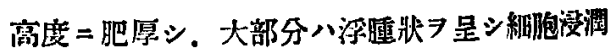

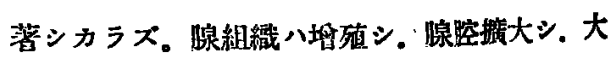

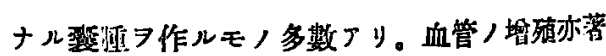
明ナリ。上皮組織八舦䐋崩壤シ，盃狀緗胞著明 二塯加ス。又圆形細胞ノ浸潤

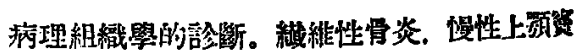
炎。

（2）右側。標本部位. 第 2 小目端。

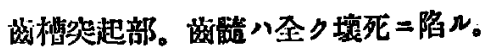




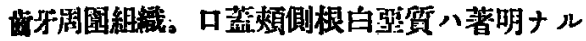

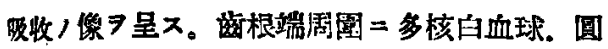

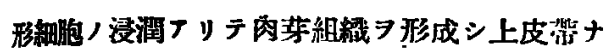

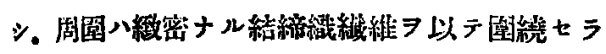
ル。周圍骨梁ノ暖收像著明ニシテ，破骨緗胞基

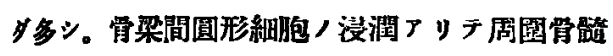

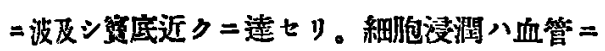

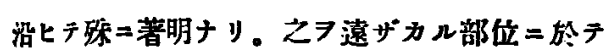

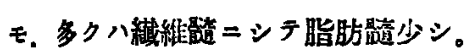

盗底骨部，皮翼习成ス骨壁八粗ニシテ肥厚增

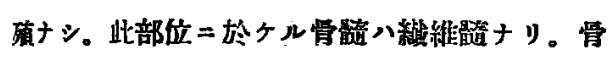

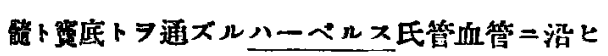

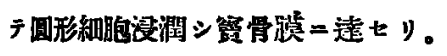

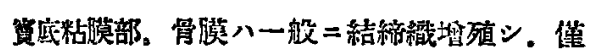

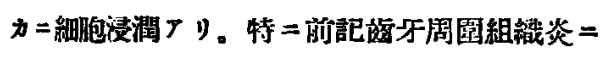
政妾ハーベルス氏管附近二於テ圆形細胞，浸閵

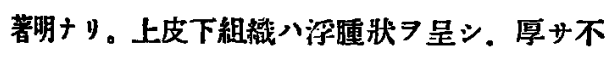

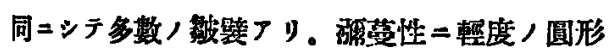

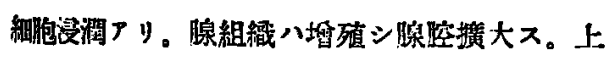
皮八破境制脆シ（人工的ナラズ）著明ナル甭狀 綳包人增加 7 見几。

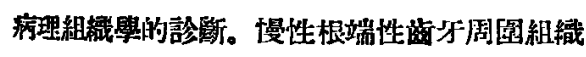
炎. 慢性根端性骨炎. 慢性上顎筑炎。

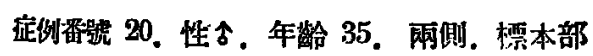
位. 第 2 大日燐。

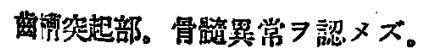

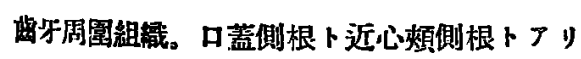

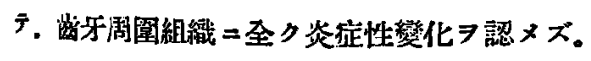

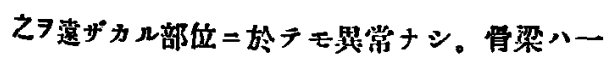
般二米縮七ス。

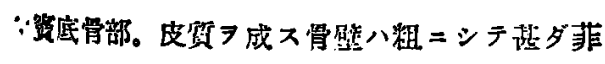

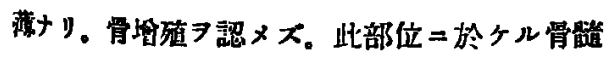

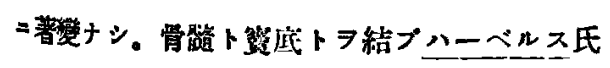

笛アレドモ買常ナシ。

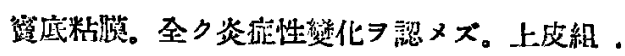

織八所々人工的二判璄又。

病理組織學的訟斷。哄常ナシ。

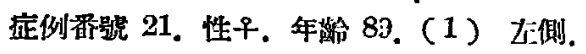

標本部位。第 2 大曰俻。

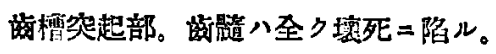

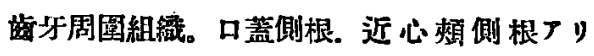

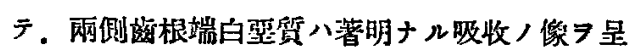

ス。根端=上皮帶 7 有ス儿肉芽組織 7 形成シ。

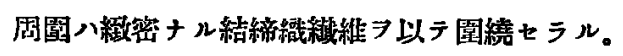
周图骨梁入吸收サン。其間圆形細胞浸潤フリテ

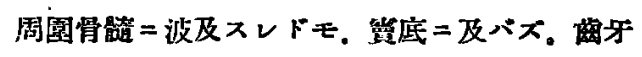

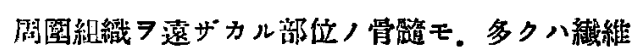
體トナレリ。

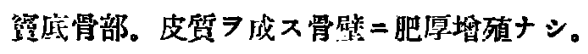

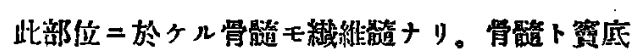
トヨ通スルハーペルス氏管ニ八買常フ認メズ。

筑底粘膜部。全ク炎症性䜌化

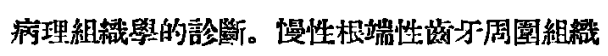
炎. 慢性根端性督炎。

（2）右側，標本部位，第 2 小曰蒛。

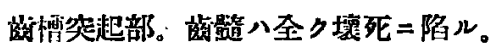

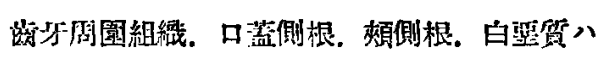
著明ナル吸收像 7 呈ス。齿根端二上皮溜 7 有

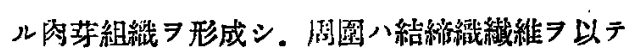
圆繞七ラル。周園骨梁八吸收サレ，其間圆形納

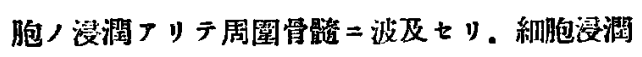

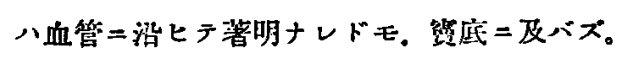

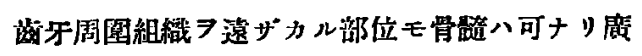

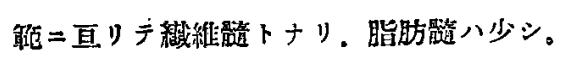

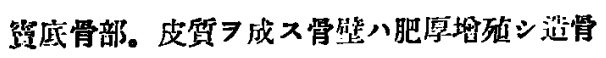

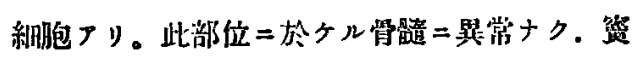




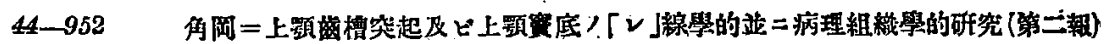

底二通ズルハーベルス氏管ニモ異常习認メズ。

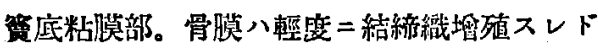
モ。細胞浸潤ナシ。上皮下組織ハ主トシテ結縍 織習殖シ白血球ノ浸潤少シ。腺組倳八堽殖シ腺

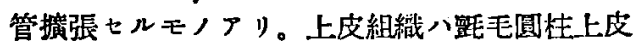
ニシテ．盃狀細胞睤扣ス。

病理組織學的診斷。慢性根端性萄牙周園組緎 炎. 慢性根端性骨炎. 慢性上顎管炎。

症例番號 22. 性早. 年路 76. (1) 左側. 標本部位. 殆ンド無齿上硕ニシテ.大日通二該 谟スル部位。

料槽突起部。骨梁ノ萎縮著明ナリ。骨䯠八脂 肪細胞ヨ以テ充タサレ。炎症性變化 7 認タズ。

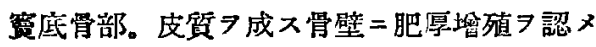

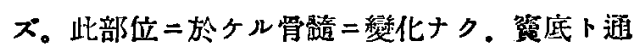
ズルハーベルス氏管＝モ異常习認メズ。

媱底粘膜部。骨膜八結䋨織㐿殖シ肥厚スレド

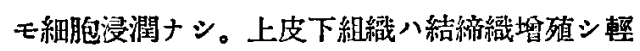
度八浮腫卜白血球浸潤厂リ。腺八輀度二增殖シ 腺管拱張七ルモノアリ。上皮組織入壇毛圆柱上 皮ニシテ白血球浸㴸フリ. 所々人工的二剝說 x。

病理組織學的診斷。慢性上額算炎。

（2）右側，標本部位，第 1 大臼俻。

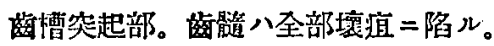

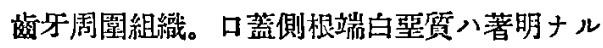
吸收, 集 7 呈ス。根端部二多核白血球. 圆形細 胞ノ浸潤アリテ。肉芽組織 $フ$ 形成シ上皮帶ナ

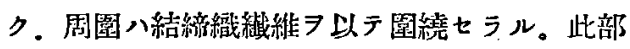
ノ骨梁八吸收七ラレ。其間圆形細胞, 浸潤〉リ テ僅カ二周圍骨䯣二波及スレドモ管底二及バ

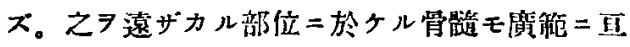
リテ繊維髓トナレリ。

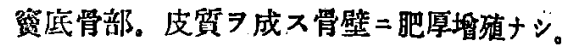

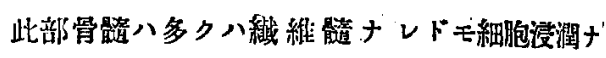
シ。簣底二通ズルハーベルス氏管キハ異常ナ *。

㛀底粘膜部。炎症性變化 組織》人工的 $=$ 所々剝㧤ス。

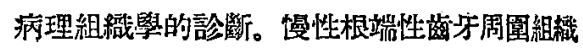
炎。慢性根端性骨炎。

症例番號 23. 性占. 年龄 41.（1）立側。 標本部位. 第 2 小目㕼。

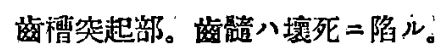

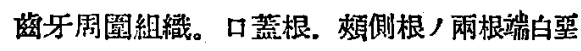
質ハ著明ナル吸收ノ像户皇え。根端部に當りテ 肉芽組織 $フ$ 形成シ周圍二絓密ナル結䋨織厂リ。 肉芽組䄉八主トシテ「ブラスマ」細胞ヨリナリ。

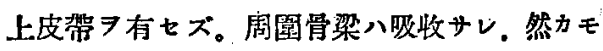

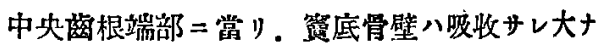
ル骨ノ缺損 7 認么。此部位八前記肉莱組織周壁 ノ緻密ナル結䋨織 ヨ以テ埋メラレ。多㤥白血 球。圆形細胞浸潤シ直接上领篮骨膜 $=$ 移行 肉莱組織周壁, 骨梁間二八僅力二圆形緗胞浸潤

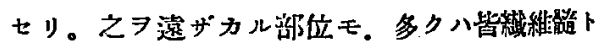
ナレリ。

管底骨部。民質 7 成ス骨壁三肥厚筧殖ナシ。 遥根端二隣接スル部位八前記，如ク．䠛牙淍園 組䄉炎，䈍入西收缺損 7 見。其間細胞浸㵎/波

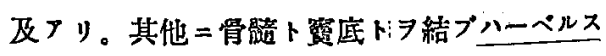
氏管习見ズ。

盗底粘膜部。骨膜八一般八結䅭織算殖セルモ

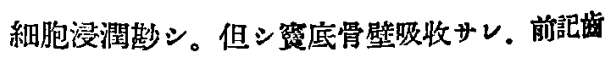
牙周罙組織炎症波及七儿部二於テ八。特=緗狍

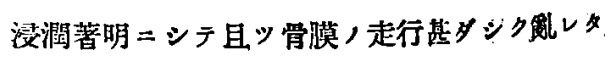
リ。上皮下組織ハー部ハ浮重状トナ、リ、一部 = 
於テハ反ッテ結稿織算殖シ。其間多核白血球，

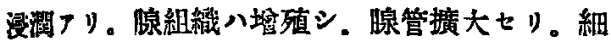

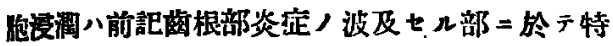

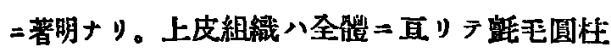
上皮ニシテ. 盃狀細胞增加シ所々人工的 $=$ 剥脱 x.

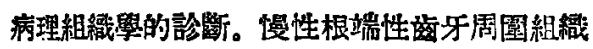
炎。侵性根端性骨炎。慢性上頻䈏炎。

（2）右側. 標本部位. 第 2 大日齿.

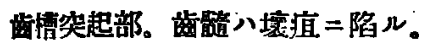

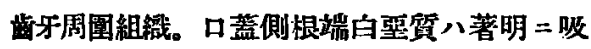

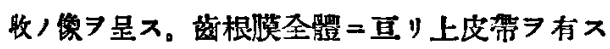

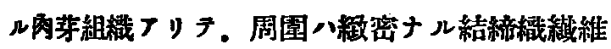
フ以テ圍繞セラル。周園骨梁八吸收廿レ其䦨圆

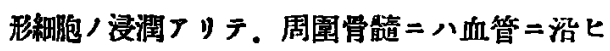

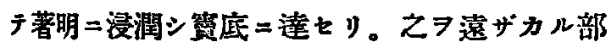

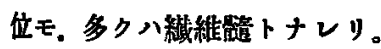

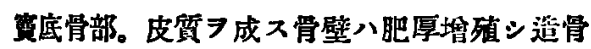

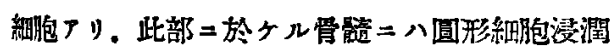

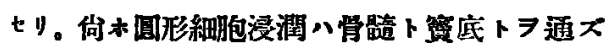
ルヘーペルス氏管內血管二沿ヒテ算底骨膜二没 及七り。

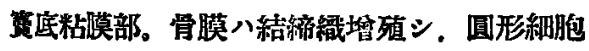
ノ浸潤厂リ。特二齿牙二近接七ル部二於テ著明 ナリ，上皮下組織八結締織增殖シ多核白血球，

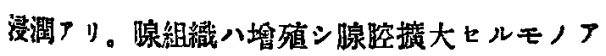

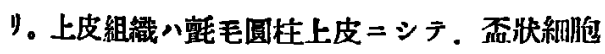
㙁加シ。白血球ノ浸潤厂リ。

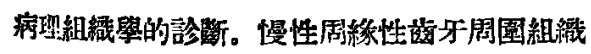

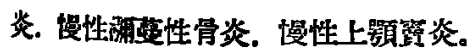

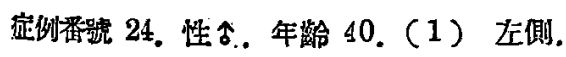

標本部位. 第 3 大目齿。

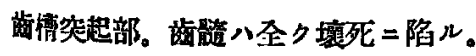

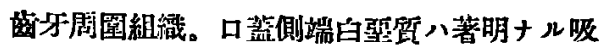
收, 像 形細胞ノ浸潤フリテ，肉莱組緎习形成シ上皮帶 ア有七ズ。周圍ハ緻密ナル結絃織 ラル、コトナク. 直チ二境界不明二骨梁二移行 ス。周園骨梁八吸收せラン。其間圆形細胞，浸

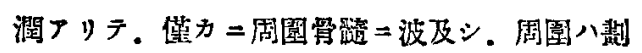

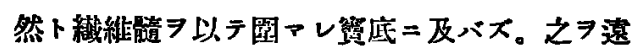
ザカル部位ニテモ多ク八繊維㗻トナレリ。

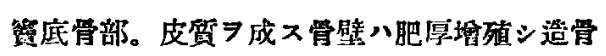

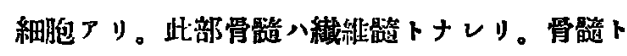
空底トヨ通ズルハーベルス氏管ニ八著變ナシ。

筧底粘膜部。骨莫! 䡍度二肥厚スルノ

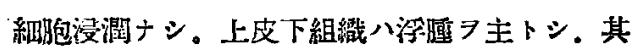
間僅カ二多核白血球ノ浸潤アリ。腺組織八整度

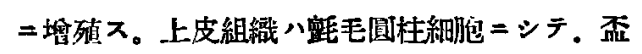
狀細胞多シ。

病理組緎學的診斷。慢性根端性药牙周園組䇅

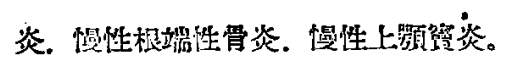

（2）右側，標本部位，第 2 大日药通。

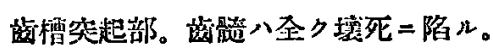

迤牙周園組織。口薏側根端白亞質八著明ナ吸

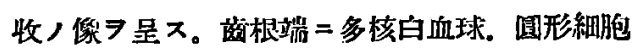

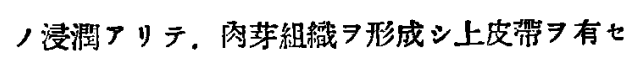

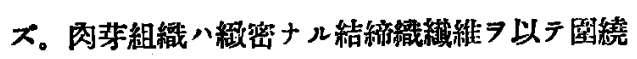

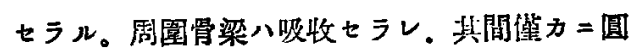

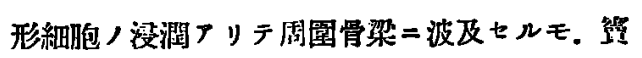
底卜，間二八台ホ正常ナル骨髓フ以テ境せ

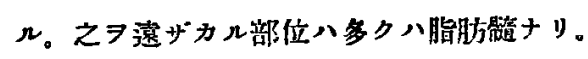

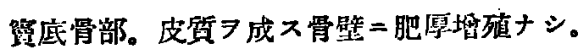

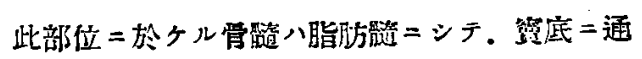
スルハーベルス氏管二異常ナシ。

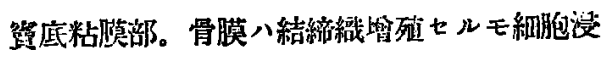




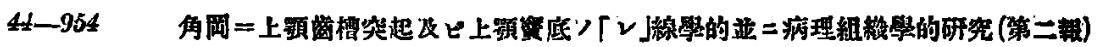

潤ナシ。上皮下組織ニハ济尰つソテ。其間圓形

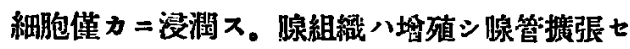

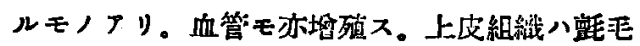
圆柱上皮ニシテ，盃祁細胞增加 ス。

病理組織學的診斷。慢性根端性隆轩周圈組織 炎, 慢性根端性骨炎. 慢性上頻琵炎。

症例番躆 25. 性早. 年敬 64. (1) 左侧.

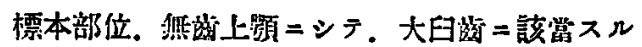
部位。

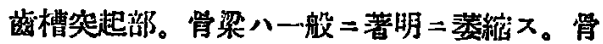
醞八筧底骨部 炎症性變化 $\boldsymbol{\text { 見 } ス 。 ~}$

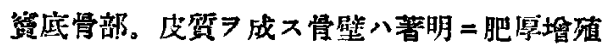
シ．造骨細胞〉リ。此部位二於ケル骨䯕二八圆

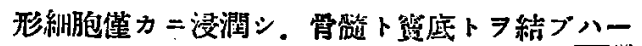

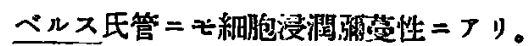

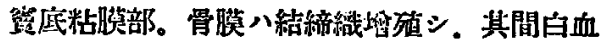
球ノ浸㵎著朋ナリ。上皮下組織八極メテ高度ナ

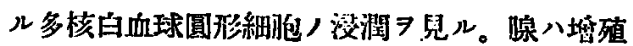

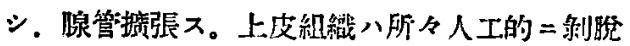
シ. 盃狀緗胞堺加

痛理組織學的診斷。慢性上枵页炎炎。

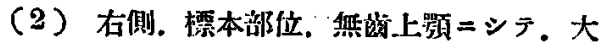
日药的二該淔スル部位。

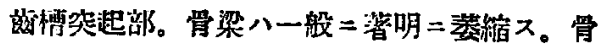

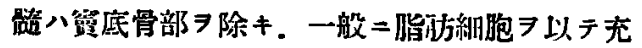

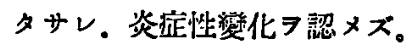

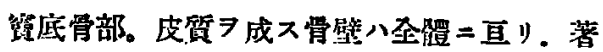
シク肥厚堺殖シ。造骨細胞フリ、此部骨體並= 骨䯕卜管底トラ通ズルハーペルス氏管二八圆形 細胞源蔡性二浸潤七り。

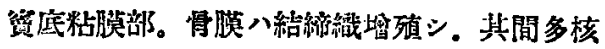
白血球，圆形細咆／浐潤著明ナソ。上皮下組䋨
八梗メラ高度ナル多核白血球。国形細刨，浸阔

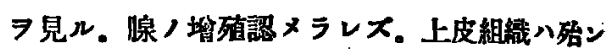

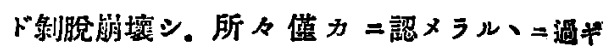

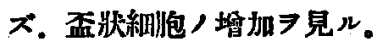
病理組織學的猃断。慢性上影签炎。

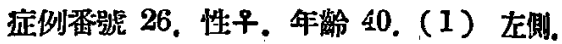
標本部位. 第 2 大日觜。

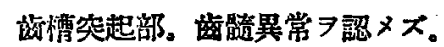

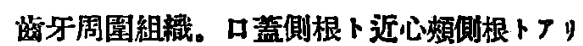

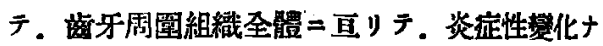
シ。そフ遠ザカル部位二於テモ異常ナシ。骨梁 八一般二篓縮七ズ。

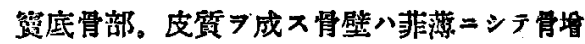
殖ナシ。此部骨䯕二著變ナク．筧底ト通スル ヘ一ペルス氏管 =モ異常 フ認メズ。

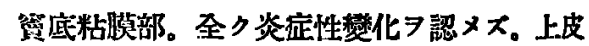
組織八所々人工的 =剥脫ス:

病理組栈學的診斷。異常ナシ。

（2）右側. 標本部位. 第 1 大日齿。

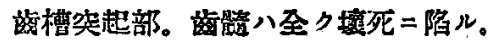

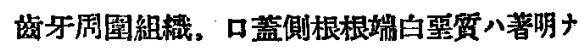
ル吸收，像 7 星ス。㷰根端=八上皮带习有スル

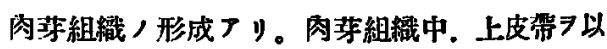

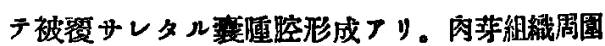
八維密ナ几結締織繊維 骨梁ハ吸收サレ，其間圆形細胞，浸閵习見周国 胃髄二波及ス。細胞浸潤八血管二沿ヒテ．著朋

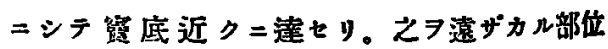

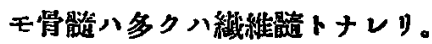

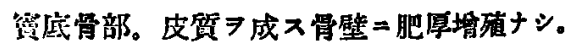

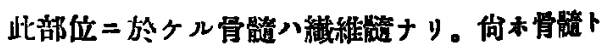
筧底トラ通ズルハーベルス氏管血管二沿にテ园

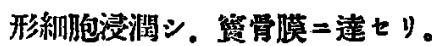




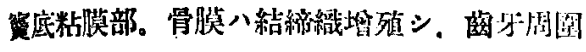

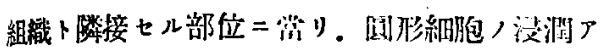

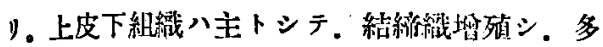
核白血球。圆形細胞ノ浸澗少シ。腺組織, 垉殖

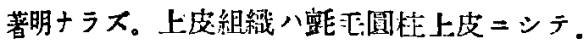

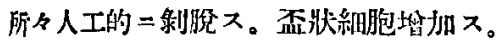

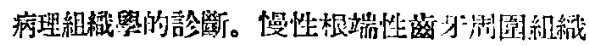
炎. 慢性根端性骨炎。慢性上敫得炎,

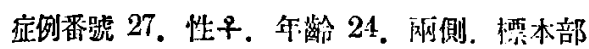

\section{位. 第 2 大目落。}

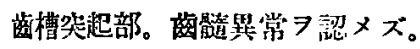

齿牙周圍組織。口蓋側根卜近心頓側根トアリ

テ. 落才周圍組織全體二亘りテ。炎症性變化 認メズ。之ヨ遠ザカル部位二於テモ黑管ナシ。 骨梁八一般二苳縮七ズ。

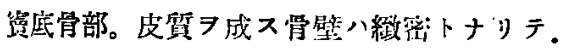
著明=肥厚算殖シ造骨細胞

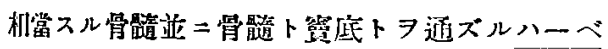
几ス氏管二僅カ二圆形綝胞ノ浸润アリ。

筑底粘膜部。骨膜八結䋨織㙁殖シ，俻力 $=$ 細 胞浸㵎厂リ。上皮下組織八宮底ノ浮腫习呈シ。 其間 =白血球浸㵎 ルモノフッ。血管壁/肥厚著明ナリ。上皮租織

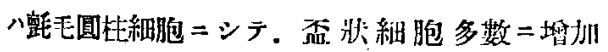

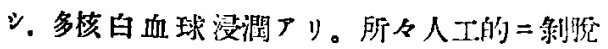
z.

蒋理組織學的診断。慢性上硕唯炎。

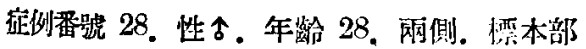
位、第 1 大曰齿。

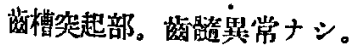

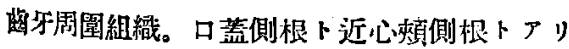

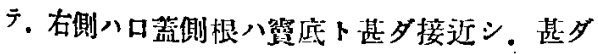

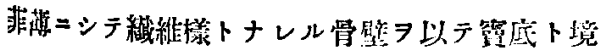

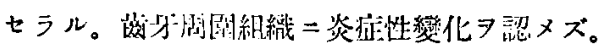

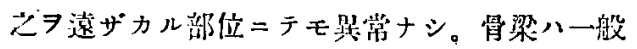
二萎縮セズ。

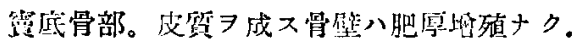

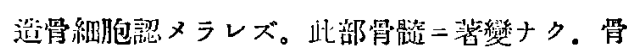

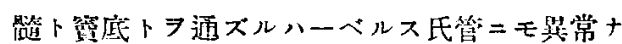
シ。

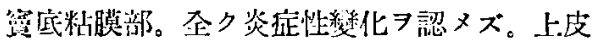

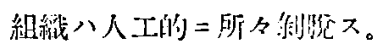

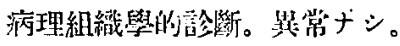

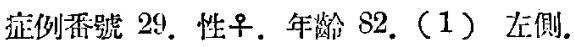
權朴部位，第 1 大的紧。

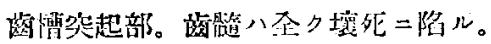

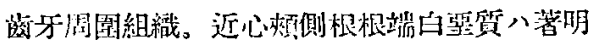

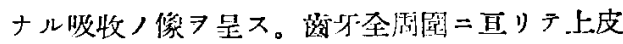

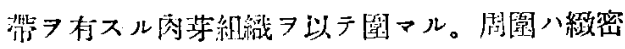

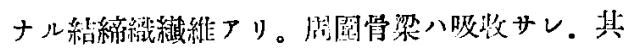

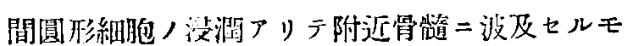

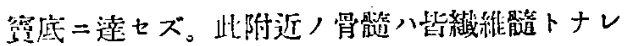

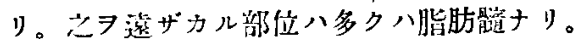

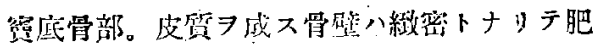

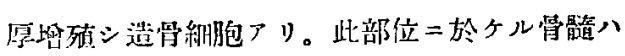

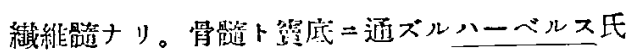

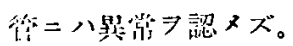

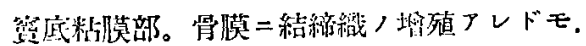

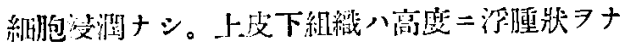

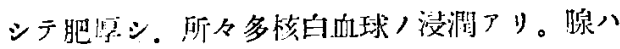

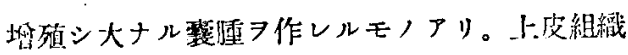

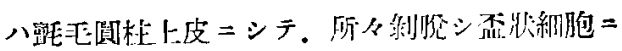

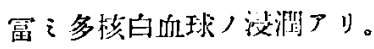

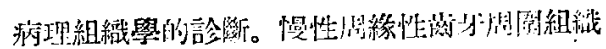

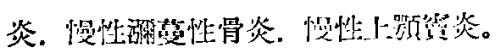

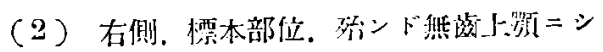


テ.大臼薂二該當スル部位。

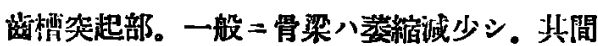

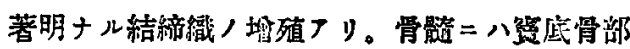
ヨ除キ。細包漁榈

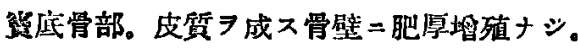

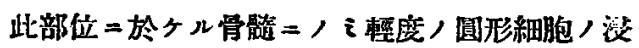

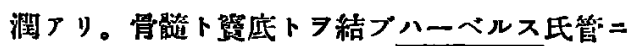
モ. 研裳性二圆形細胞浸潤七り。

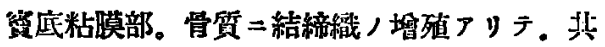
間多核白血球ノ浸㵎アリ。上皮下組織八不正 $=$ 肥厚シ。高度ノ多核白血球ノ渗㴸アリ㟫管八硡 ンド認メラレズ。上皮組䋨八壇王囯柱細胞ニシ

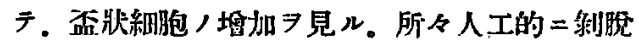
z.

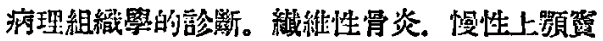
炎。

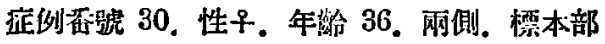
位. 第 2 大臼蒛。

离槽突迪部。落艏二異常ナシ。

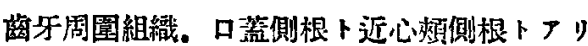

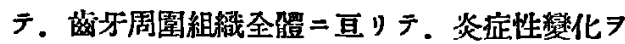
認メズ。そヨ遠ザカル部位ニテモ異常す認メ ズ。骨梁ハ一般二萎縮セズ。

算底骨部。皮翼习成ス骨壁二肥厚增殖ナク。

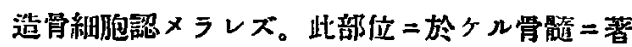

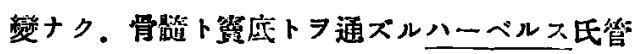
ニモ異常ナシ。

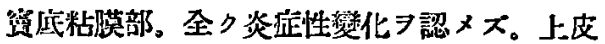
組戠八人工的 =所々剩脆シ. 盃狀細胞塯加七 1)。

症理組織學的猃斷。異常ナシ。

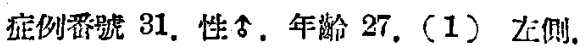
標本部位。第 1 大田旨。

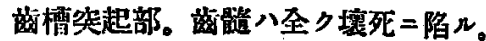

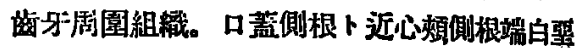
買八著明ナル吸收/像 血球. 圆形細胞/浸潤フリテ. 肉芽組蟣

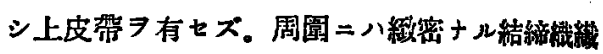

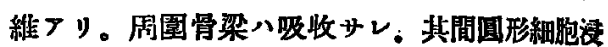

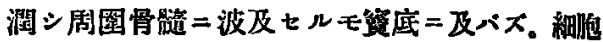
浸潤八血管周園二沿ヒテ著明二進行ス。骨梁二

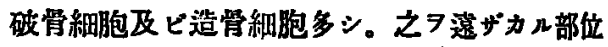
モ皆瀻維䯕トナレリ。

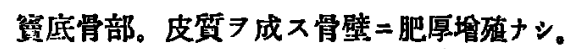

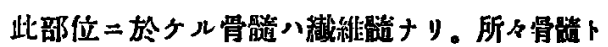
䈍底トヨ結ブハーベルス氏管アレドモ。異常 認メズ。

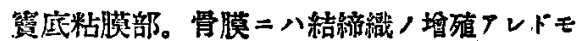
細胞浸澖ナシ。上皮下組織ハ澡隀狀ヨナシテ肥

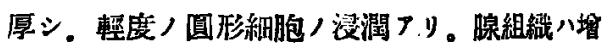

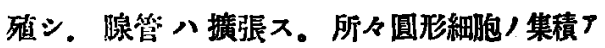

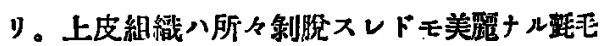
圆柱細胞ニシテ，一般=盃狀細胞增加ス。

病理組織學的診断。慢性根端性齔牙周圍组織 炎。慢性根端性骨炎。慢性上颚签炎。

（2）. 右側. 標本部位。第1大日齿。

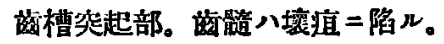

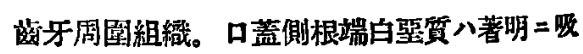

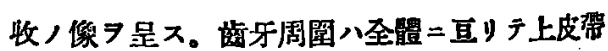

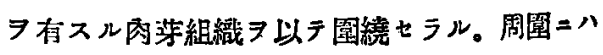

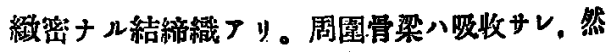

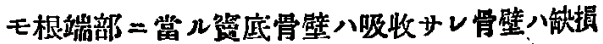

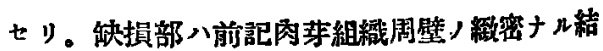
䋨㵶フ以テ埋メラレ，其間多核白血球。园形緗

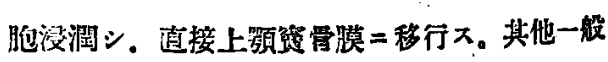

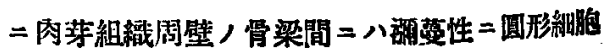




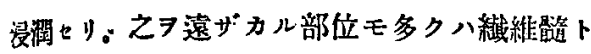
$+2 \%$ 。

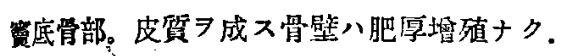

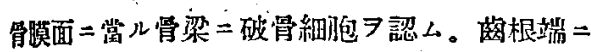
相常スル部位八，前記ノ如ク骨吸收サレ，細包

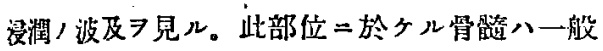

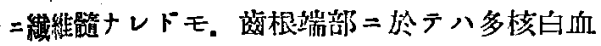
球. 圆形細胞浸潤シ。該部ョリ畋底二通ズルハ

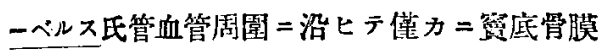
二波及スルラ見ル。

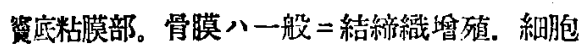
没潤ナキモ齿根部卜近接ス儿部位八結䋨織增殖 シ. 圆形綝胞/浸潤ノリテ特二䇺底骨壁缺損部 ニ當りテ著朋ナリ。上皮下組織八全體二亘り輕

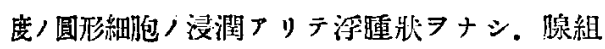

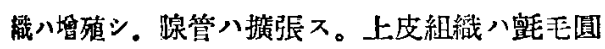

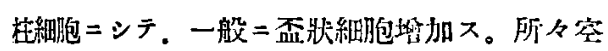
胞存又。

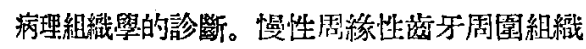

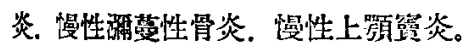

症例番號 32. 性占。年䈣 27. (1) 左倒. 標本部位. 第 2 大且落。

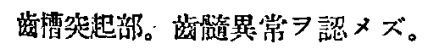

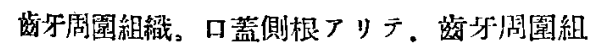

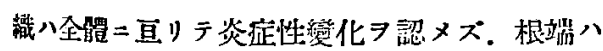

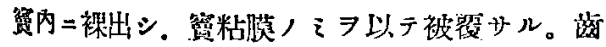
牙周圈組織 䔔ザカル部位ニ於テモ異常ナシ。 骨梁へ一般二萎縮セズ。

管底骨部。皮質 $ラ$ 成ス骨壁二肥厚增殖ナク。 造骨緗胞認メランズ。此部位二於ケ几骨路二異 常ナっ，骨踏卜管底トヨ通ズルハーベルス氏管

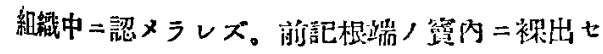

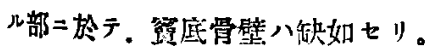

算底粘膜部。全ク炎症性變化 組糡八所々人工的二剥脫入。

病理:組織學的搒斷。異常ナシ。

(2) 右側。標本部位. 第 2 大四齿。

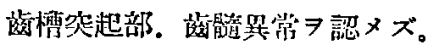

荡牙周圈組織。口蓝側根卜近心规側根〉リ

テ. 逄牙居图組織二八全ク炎症性變化 7 認又

ズ。えヨ逗ザカル部位二於テモ異常ナシ。骨梁 八一船二薄縮セズ。

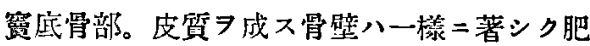
厚箸殖シ所々造骨細咆习認ム。此部位ニ於ケル 骨䯣二著紮ナシ。所タハーベルス氏管フリテ。 骨觜卜筧底トヨ通ズルモ黑裳ナシ。

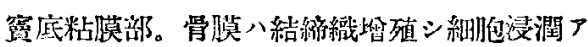
リ。上皮下組織・一般二結䋨織多ク，多㤥白血

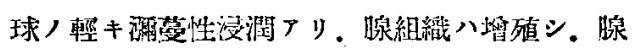
管八著明二撗㖘ス。所々圆形細胞浸潤 /集積 リ。上皮組織ハ總べテ人工的二削脫ス。

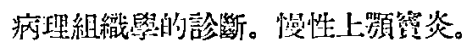

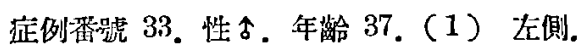
摽本部位. 第 1 大田蔏。

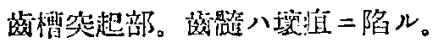

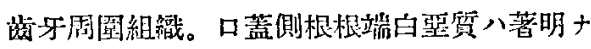

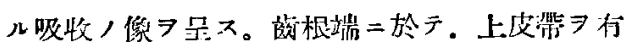
スル肉茅組織习形成シ。主トシテ多核日血球 $\exists$

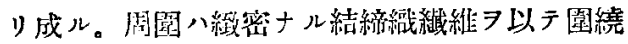
七ラル、モ。们木闪获組織,多核自血球八。此

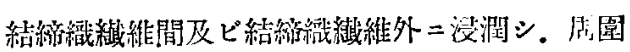
骨留道二波及シ。慢性炎症八急性塯瑟，轉機

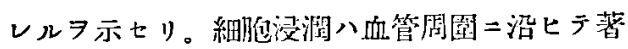

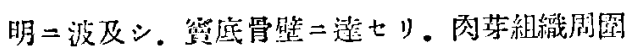
，骨梁八著明二吸收》レ。其一部八骨梁八境瘨

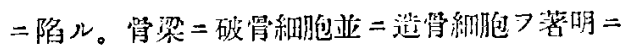


臸么。

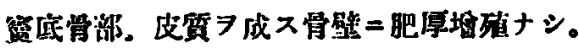

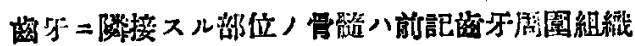

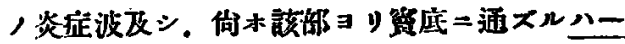
ベルス氏管血管阔圆二沿ヒテ細胞浸潤シ签骨䑏

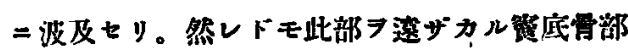
ニ八基常ナシ。

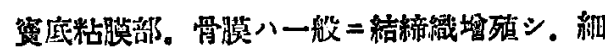

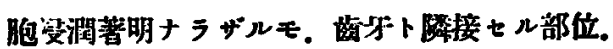

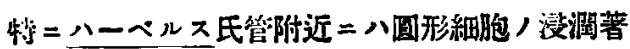

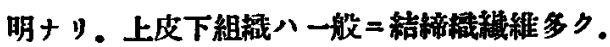

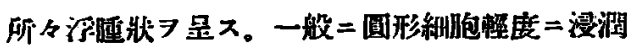

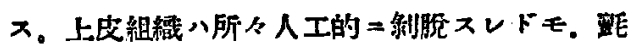

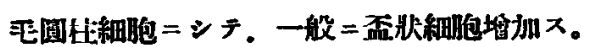

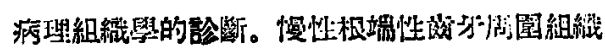
炎(急性炎症，轉機 骨炎。惨性上影筧炎。

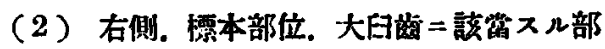
位。

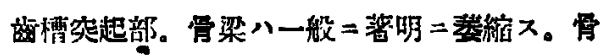
锗八脂肪細胞 メズ。

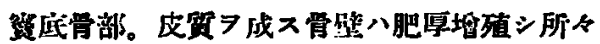

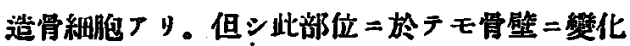
ナク，算底二通ズルハーベルス氏管二モ異常 認メス。

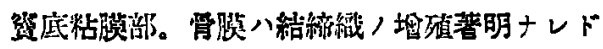

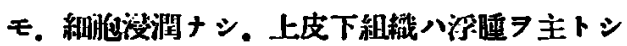

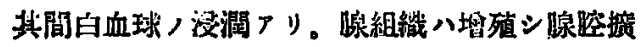

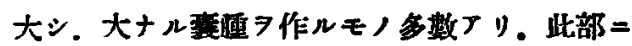

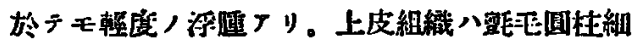

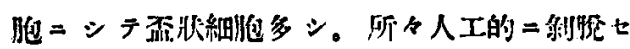
y.

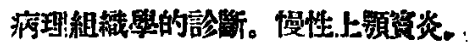

第 四 龺

\section{病理解剖學的所㫕}

總括並二考接

第一笛 肉䖨的所見二就

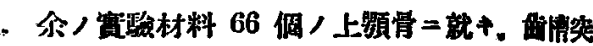

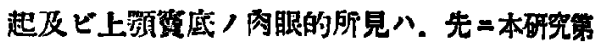
一報二於テ速べタルトコロナルヨ以テ、今之す 總括的二速ベントス。

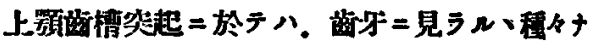

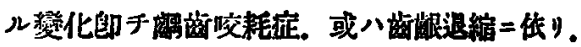

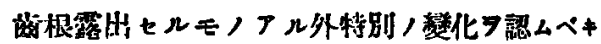

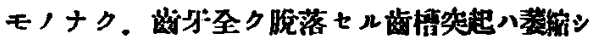
ラ权坦トナレリ。

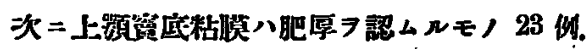
盵厚フ認メザルモ， 43 例ナリ。

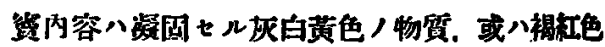

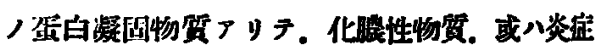

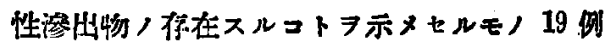

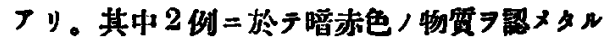
八. 死後出血二由來スルモ，卜思惟七ラル。

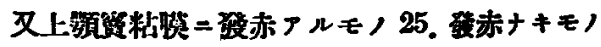

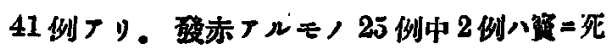

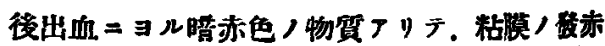
八恐ラク死後出血 $=\Xi$ 血被沦降 Hypostase ニヨルモノナラン。

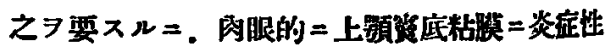
變化 7 認ムルモノ八23侧ニシテ比较的抄り。

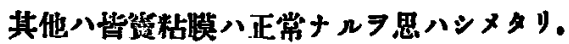

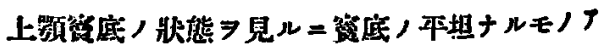

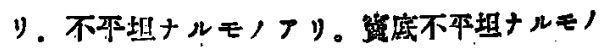

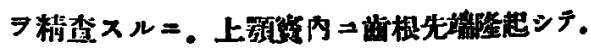




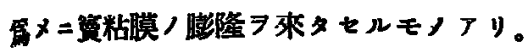

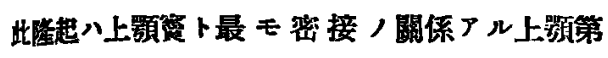
1. 第 2 大日啮及ビ第 2 小曰齿

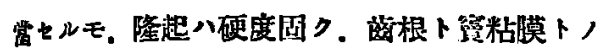
間二骨居フルワ思ハシメタリ。即チ肉眠的二八

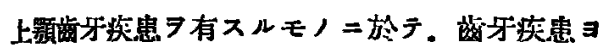

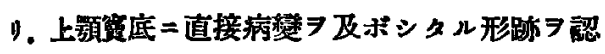
ムルモノナシ。

\section{第二節 組織學的所見二就テ}

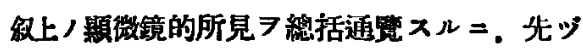
榆察把=於テ八.

（1）踒牙周圍組䄉炎 7 有スルモ，19例。

(2) 齿牙瞈落七ルモ，19 例。

（3）齿牙居圍組織正常ナルモ，23侧。

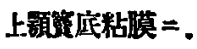

（1）慢性炎症性變化 ルモノ 44例。

（2）炎症性變化ナ +モノ 22 例。

シシテ. 肉眠的ニ八何等變化

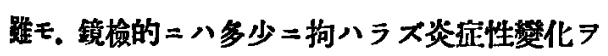
詪メタルモノ多シ。

今之等ノモノ =就キ，以下蒛少周園組織炎，齿

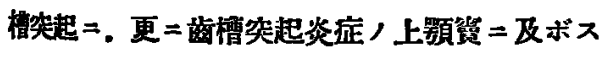

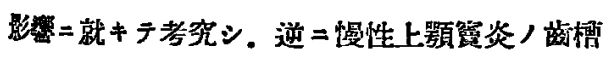

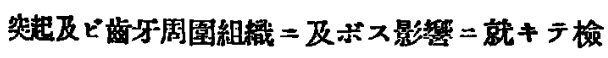
封シ。更二本實酸成績 7 基碟トシ之ト關係フル

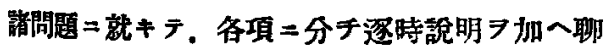
カ腒見习达ー゙ントス。

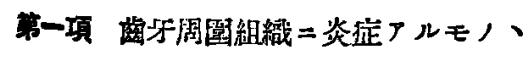
齿槽突起 ノ愁化二就テ

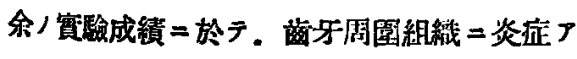
ルモノ 19 例 $=$ 就キ之 總括スルニ．之等ハ總テ 慢怕海牙周園組織炎 蚂䡛炎, 像星スルモノナシ。之等/中。

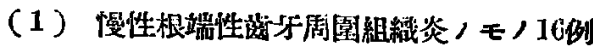
(症例番㖃。 3 右. 5 左. 13 左. 14 右. 18 左 右. 19 右. 21 左右. 22 右. 23 左. 24 左右. 26 右. 31 左. 33 左) =シテ大部分 7 与.

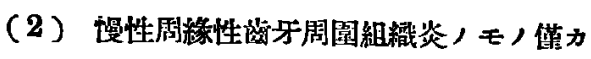
$=3$ 例（症例香號 23 右. 29 庄. 31 右 + 十。 前者八郎千. 觜根端=多核白血球. 圆形細胞，

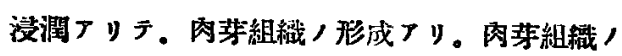

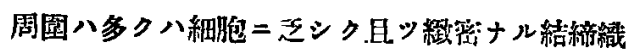

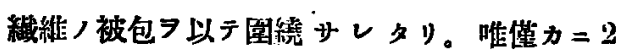

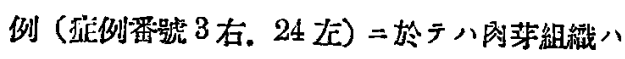

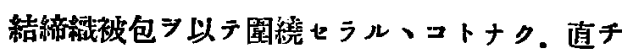

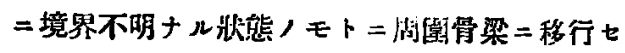
リ.

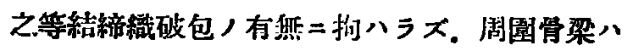

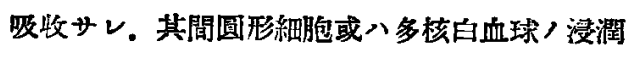
フリテ．特=血管周圍二沿七テ進行シ．皆慢

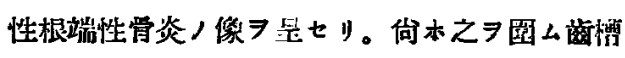

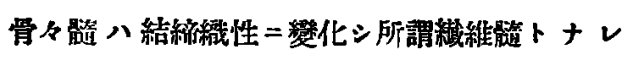
リ.

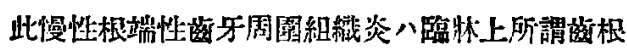
肉芽隀ト呼バル、モノナリ。而シテ余/庭例中

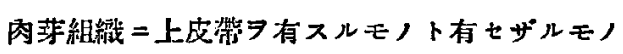

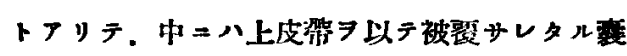
睡7形成セルモノアり(症侧䆏號 26 右側)。上

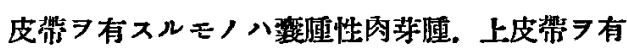

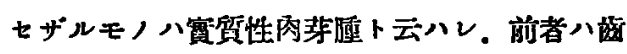

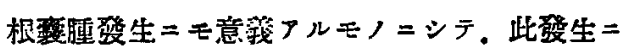

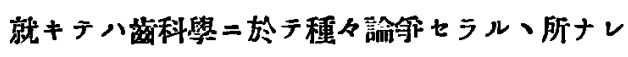
ドモ. 余 研筧目的二非ザル 以以テ詳細=就キ テハ之ア述ベス。唯ダとラ記载スルニ止メタ リ。

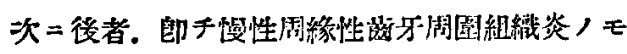




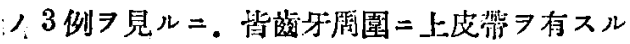

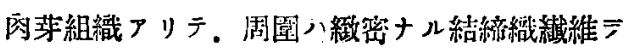
以ラ圍マル。凩图骨梁ハ吸收サレ，其間圆形細

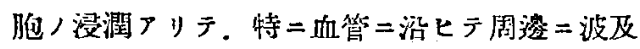

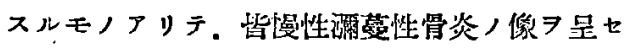

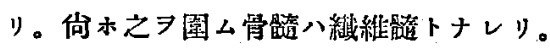
近年 Landsberger トWeski(1927)

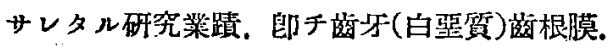

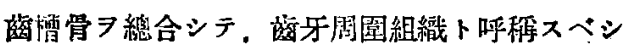
卜提唱セラレシ以來。近年齿牙疾患 7 諭ズル場

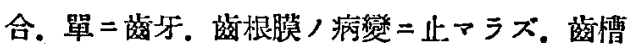
骨ノ病變二就キ洼目スルニ至レルハ。當然ノ理 ト云つア得ベシ。從ツテ之二關スル研垫モ日 追ツテ益に盛ナラントスル超势こアルハ方故ナ キニアラズ。

Siegmund-Weber(1926)）八根端性荡牙周園組 織炎ハ即于骨炎ナルコトヨ逃べ。以前ヨリ記载

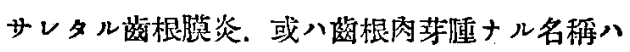
索筫病理組織學上正シカラズト云へリ。

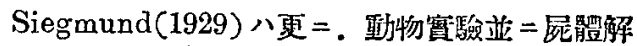
剖 =コリ頷骨二於ヶル急性海牙周圍組織炎並二 慢性齿牙㓮圍組織炎二就キ詳述シ。此慢性齿牙 阔圍組織炎, 原型八限局性粗影性骨炎ニシテ。

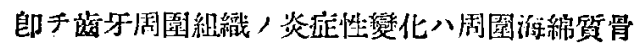
篴二波及スルモノナリト云へリ。 近年 Wassmund(1935) 八骨炎 $习$ 臨林上ヨリ種 程ナル型二分類セり。郎チ (1) 沴出性骨炎.

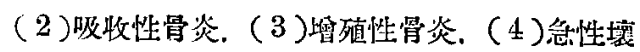
誼性骨炎(骨髓炎). ( 5 ) 慢性骨照造炎二分類シ得 ルモノナリト述ベタリ。

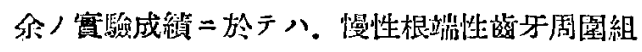
織炎アルモノ八慢性根端性骨炎 7 。慢性周榢性

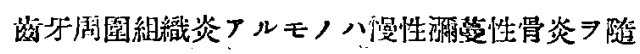

伴セルア以テ，略を Siegmund, Weber y主

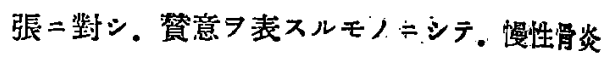
，細胞浸潤八血管周圍二沿七テ．著明二波及

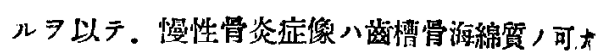

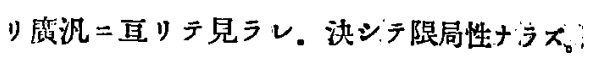

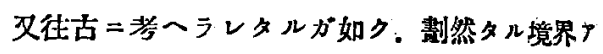
ルニ非ラス。

由是䘽之. 慢性齿牙周園組織炎症，齿慒骨=波 及スル場合. 先ジ血管周圍 =沿ヒテ浸潤進宁 シ. 次イデ慢性骨炎八娜時攄大スルモノニシ テ，血管周圍組織八骨炎八進行波及二際的重大 ナル役割ヨ演ズルモノ、如シ。

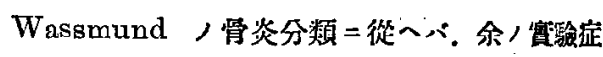
例二於々几慢性齿年周園組織炎八所謂吸收性骨 炎二該堂スルモノナレドモ。等二於テ啙䄚骨

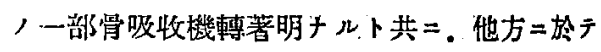

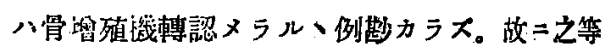

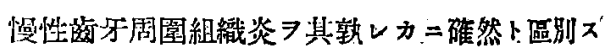
ルハ至難ノコト二屬ス。

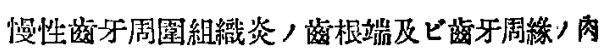
莱組織八主トシテ。圆形細胞(多っ八淋巴球。

「プラスマ」細胞)ョリナソ，且ッ周圍骨梁い

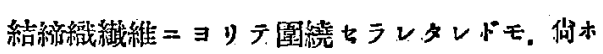
圆形細胞八風圍骨梁二浸潤シ，炎应八所謂静止. ，狀態 示シタリ。其中. 2 例（症例番號 3 右. 24 左）＝於テ八，肉芽組織八結䋨䗃被包习以 テ圈綾七ラル、コトナク．直テ二周園骨梁二移 行七ル八. 朱ダ防覙機轉ナり. 炎应!此較的急 性二造行スルコトヨ示スモノニシテ. 慢性炎症 ，中ニテモ，亞急性落枭周圍組織炎ト名ツクベ キモノナリ。

其他. 小数例 (症例番栫 5 左. 33 左) =於テ”

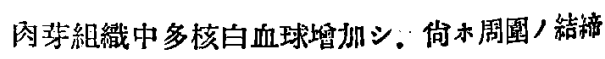




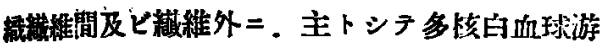

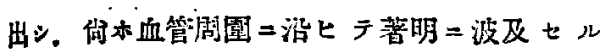

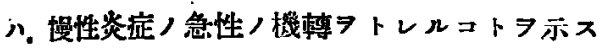
モルナリ

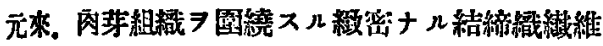

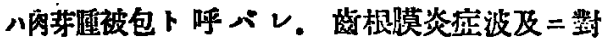
シ。防徖機能ヨ有スルモノト考へラレタレド モ. 如斯. 慢性炎症ノ急性炎应アトレルモノ八 物緰。慢性炎症，静止，爿態二於ラスラ. 份ホ

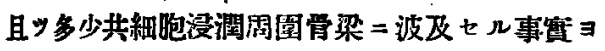

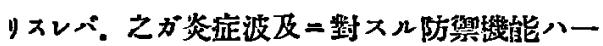
面. 稰数的ノモノニナラズ。即チえ二關シ古柬

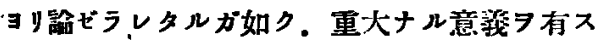
ルモノニアラザルベシト思㚘ス。

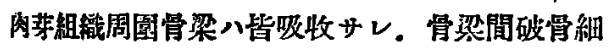
胞、造骨細胞 7 認ムルモノ多シ。其中唯ダ 1 侧

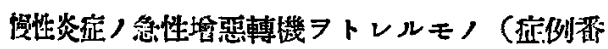

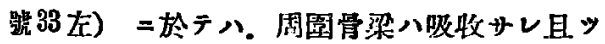

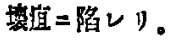

最後二慢性根端性骨资及ビ惨性磁营性骨炎炎应

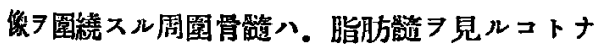

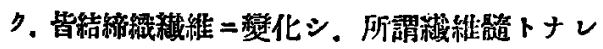

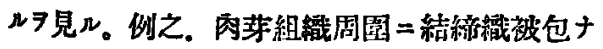
+モ（绽例番號 3 右. 24 左）二於テ，骨炎症

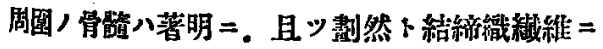
裂化セり。

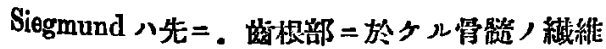
化 7 以. 酰往 $=$ 於不此部 $=$ 炎症性過程你在 ン啮左トナスコトヨ得ト云ヘリ。余八些上ノ如

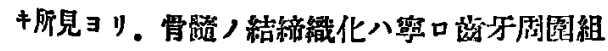

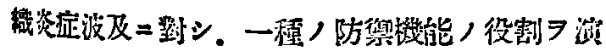
スルモノト思惟スルモノナリ。

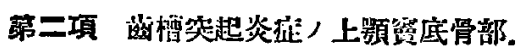
筑糊膜二及六

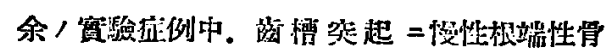

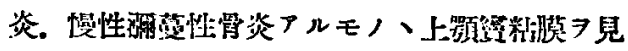
$r=$.

（1）殆ンド大部分八慢性上影琶炎，組䋊像 認又。

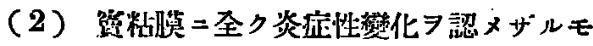

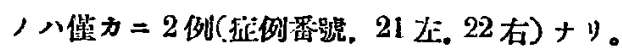

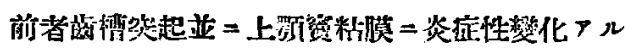
モノニ於テ.

1). 症例喟栫。13 不. 18 右. 19 右. 23 不

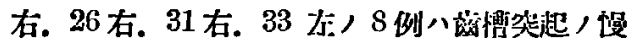

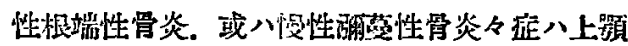

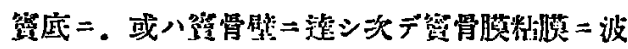
及七り。

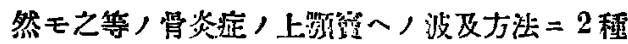
数フリ。郎テ。

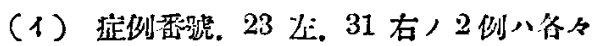

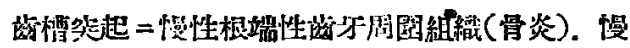

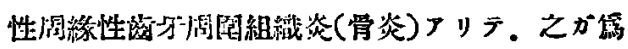

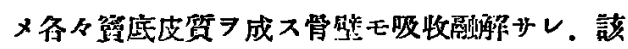

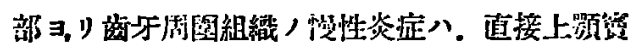

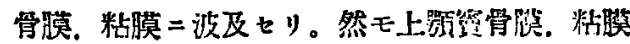
/炎拝像ハ瓷牙二搂接七ル部二於テ最モ著明ナ $\%$

（可）症例罞躆. 13 压. 18 右. 19 右. 23 右.

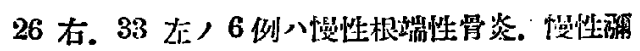

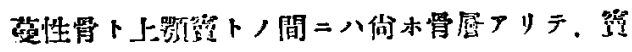

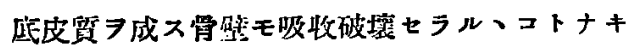

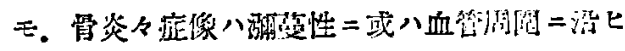

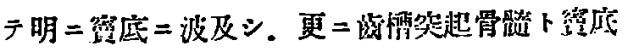

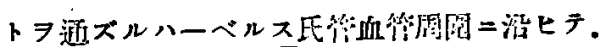




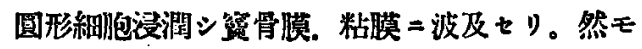

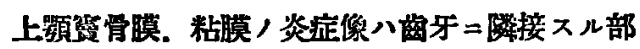
こ於テ最モ著明ナリ。

2). 其他八应例潘躆， 3 右，5左，14 右. 18 左. 21 左. 24 左右. 29 左. 31 左, 9 例八湩

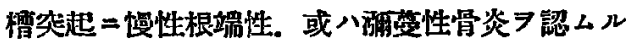

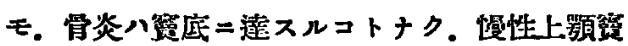

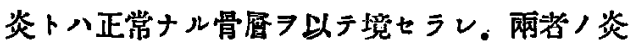
症二連絡 $尹$ 認メス。

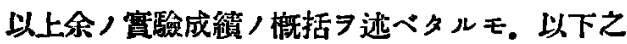

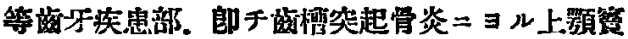
感染二就キ．種々述ベントスルニ先立チ．注意 スべキ八，等八最初ョリ其局所解剖學的關係 ショリテ左右をラル、コトナリ。

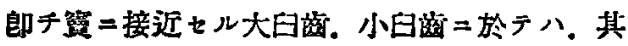

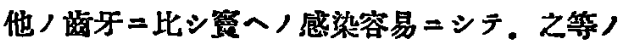

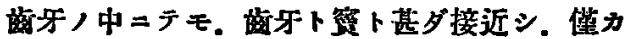
二紙狀フ成ス薄キ骨壁フ以テ隔テラル、場合。

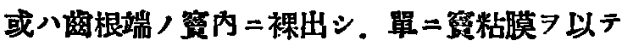

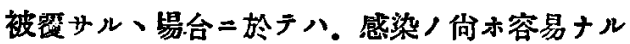
八賞然ノ理ナリ．反之．之等齿牙，中ニテモ。

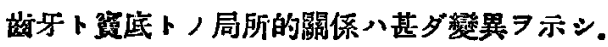

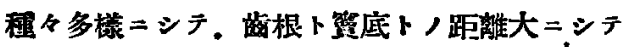

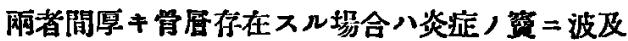
スルコト難シ。

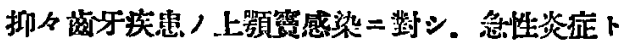

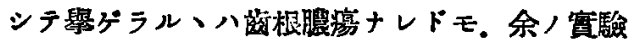


圍組織炎ノ像 シ 号スルモノハーツモ遭遇セズン

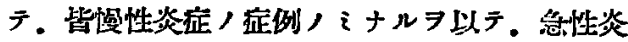
拉 二就キラ八整ク之

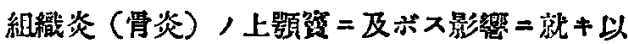

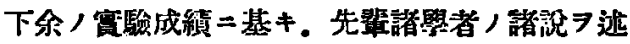

べ卿カえが荅案习試ミントスルモノナリ。

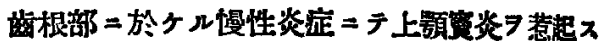

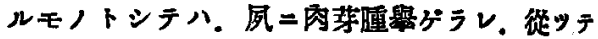

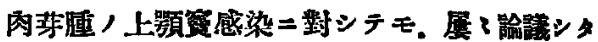
リ. 今之に關スル諸學者ノ所說习藇ジルニ。

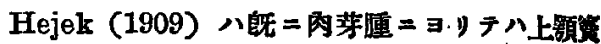
感染八頻發スルモノ＝非ズト速へ、肉芽連八 骨 7 吸收シ泚㭙增大シ。次イデ筧へ涉及スル

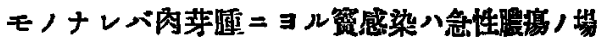
合二於ケルガ如ク．齿根ト上颚察底ト/解剖學 的姴素习必要トセザルモノナルコトヨ速ベタ リ。

其他 Partsch, Williger, Weiser, Reinmoller, Christ 等ノ齿科ノ諸大家モ舉りう肉莱腫=

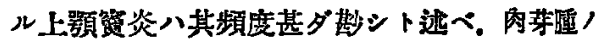

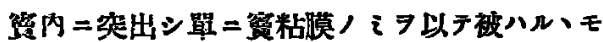

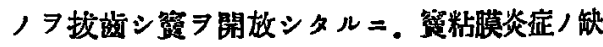
如七ル 確メタリ。

近年 Berberich(1932) 八陶莱腫 7 设性根端性

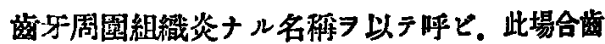
覆骨タ炎】ルコトタ認メタルモ。. 佾ホえニヨリ

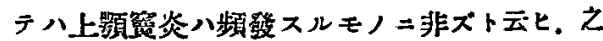

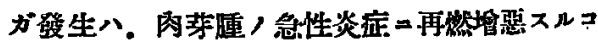
トニョリテノミ可能ナリト。

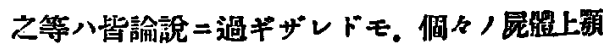
骨二就キ，組樴學的二檢菜七シモノ=Weski

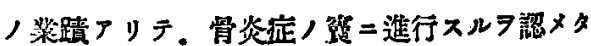

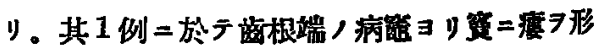

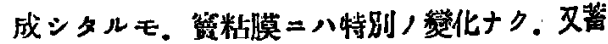

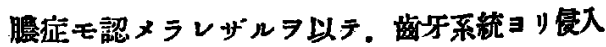

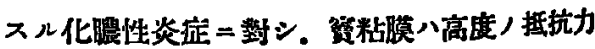
フ有スルモノナリト結䜽七り。

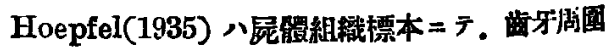




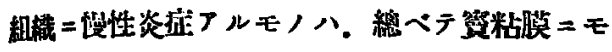

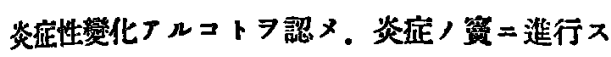
ルン八筑底骨，吸收サレルコトナクトモ。骨炎

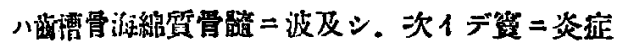

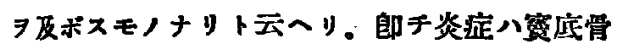
部二兄ラル、第孔管 Perforierenden KanäI-

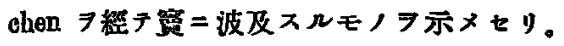

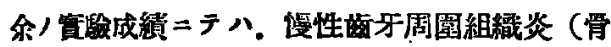

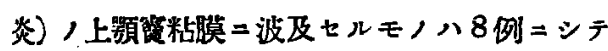
其中 2 例八算底骨壁 7 吸收シ，炎柾進行七ル

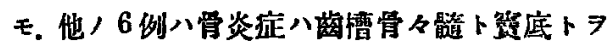
結プヘーベルス氏管血管周圈＝沿ヒテ．波及セ ルハHoepfel 八第孔管习經テ筫二波及スル

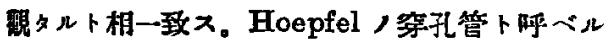
八即チハーベルス氏管ナリト思推ス。如斯。骨

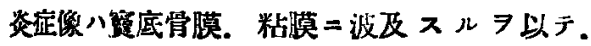
Weski ノ云へルガ如り。管底粘膜，蓫性 $コ$ リ

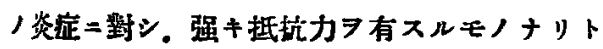
ハ考ヘラレザル所ナリ。

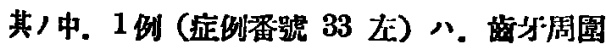

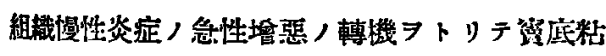
膜二波及シタルモ．其他ノ大部分（7例）八。

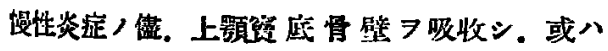
ヘーペルス氏管血管周图二沿七テ络粘膜=波及 シタリ。店㑬番號。 5 左八慢性炎症，急性轉

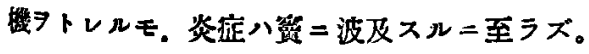

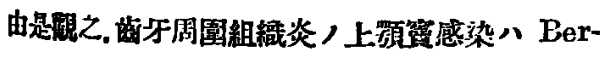
berich /云へルガ如ク.必ズシモ慢性炎症，急: 性物墨スルコトヨ必要トセザルモノニシテ。慢

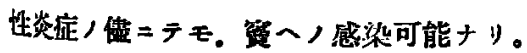

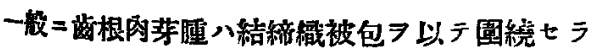

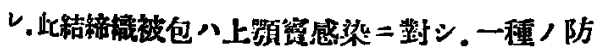
製椆/役制シナスモノト考へラレタリ。Runge,

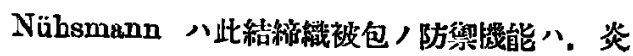

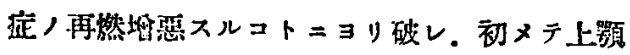
蓝二感染スルモノナリト。

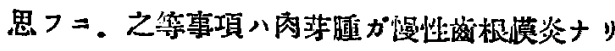

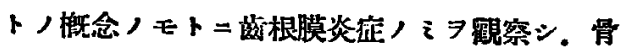
人變化. 即千骨炎二就+注意拂ハザリシコト

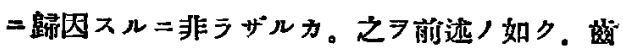

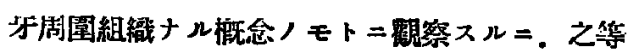

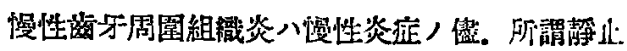

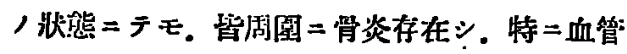

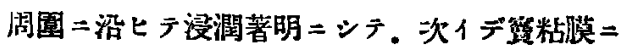
波及スルコトラ明ラカ二示七ルラ以テ. 龉根肉

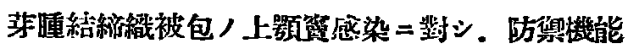
ア有スルコトニ關シテハ Runge Nühsmann /云へルガ如り. 重大ナル意㨍ブ有スルモノ: = 非ラザルべシ。

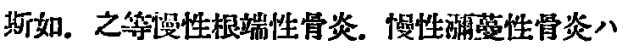

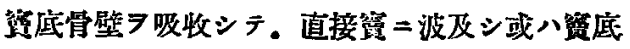
骨壁ヲ吸收スルニ至ラザルモ。骨炎ハハーべル

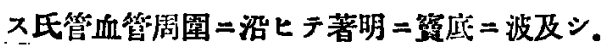

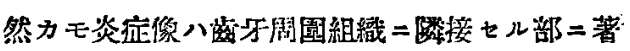

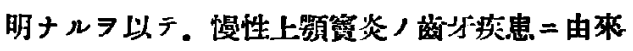
スルモノナルコト明ラカナリ。

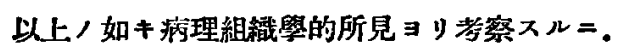

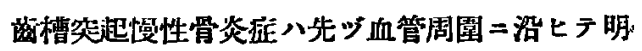
ラカ二波及七ル 進行スル場合モ亦. 先ヅ算底=通ズルハーベル ㅈ管血管周圍二沿ヒテ．波及スルモノ=シ

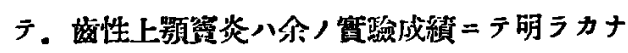
ルガ如ク．以前二於テ洘へラレタルヨリ多数依 在スルモノナリ。

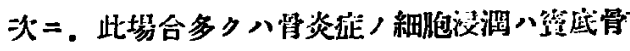

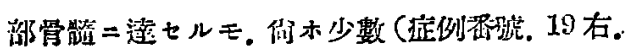




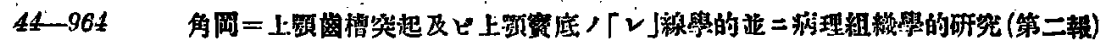

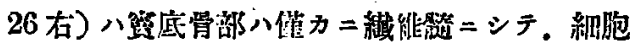
浸潤

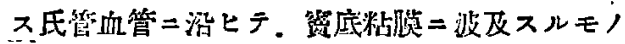

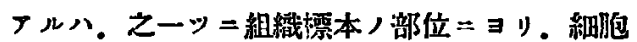

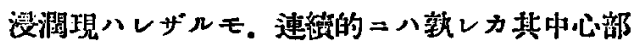

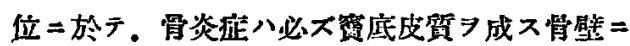
逹シ。次イテ皦底二通スルハーベルス氏管血管"

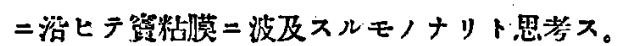

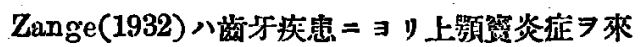

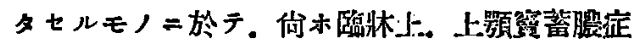

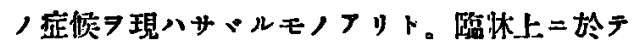
ノミ之マ端ジ。 と 7 Sinusitis comitans 隨伴

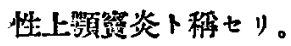

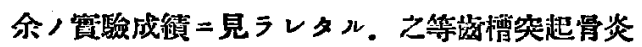

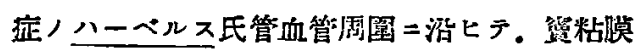
二波及スルモ，、慢性炎症，㑺經過スル場合 八. 䝀牀上如何ナル症候ヨ現ハスヤ八興味深キ

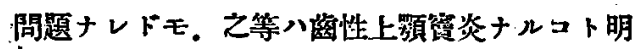
ラカンシテ，著明ナルト著明ナラザルトシ閣ハ

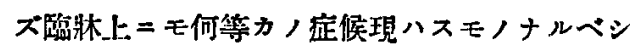
推斷 $几$ 。

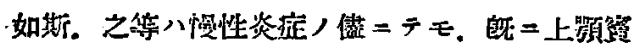
二炎症波及スルモノナレパ. 潜伏性 $=$ 經過スル

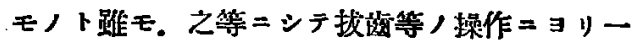
旦慢性炎症，再燃シテ念性炎㱏アトル事アラン

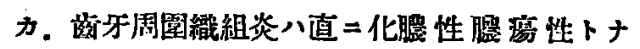
.リ. 或八骨八滾瘨二陷りテ席沉ナル急性骨炎

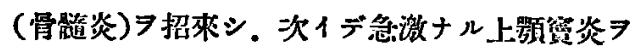
蓗赸スルニ至ラン。

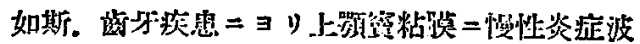

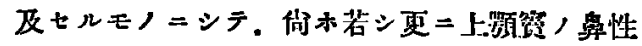

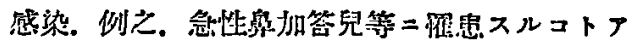

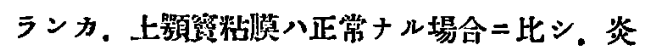

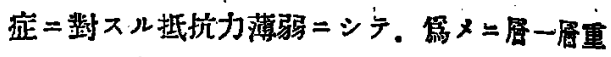

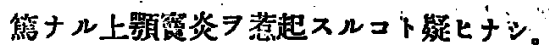

3). 次二症例番號。3右，5底，14右，18 左. 21 右. 24 左. 24 右. 29 左。 31 左” 9 侧=

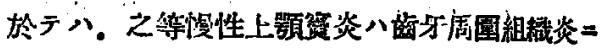
由柬スルモノナリヤ。或八感居等/際鼻腔 感染七ルモノナリヤ二就キ考フルニ。等八㫮

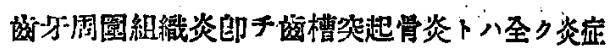

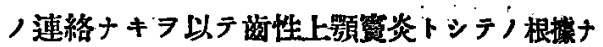

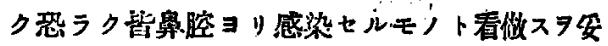
常rス。

然レドモ。等骨炎症, 初期. 郎千急性炎症，

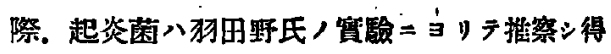

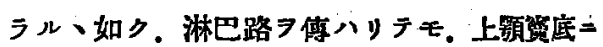
荤般七ラレ，之=轉移性二炎症习惹起ス儿場合

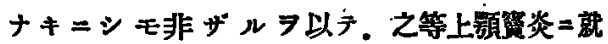

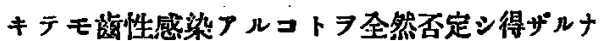
リ。

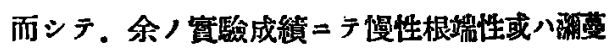
性骨炎习認丈タルモノ八.上影管粘膜二於方 モ. 又慢性炎症习認ムルモノ殆立ド多数习占

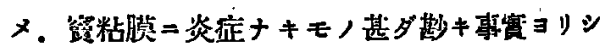

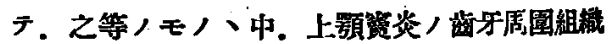
炎二的柬スルモ，ナルコトラ想像スルモ不渵: フラズ。

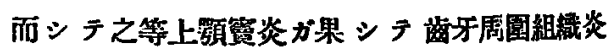

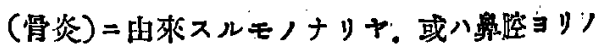

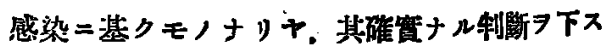
コト八容易ノ業ニアラス。

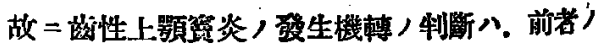
場合ノ如ク連續性ノモノ八。其制斷容易ナルモ 挠省ノ場合，多ク：中間二於テ炎症应狀著明ナ ラザルカ。或ハ全ク之テ缺如をルガ如キ場合犬 
䛿上全ク不可能ナリト云ファ得べシ。

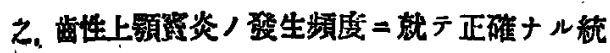
けキ藇グルコト困奞ナル所以ナリ。

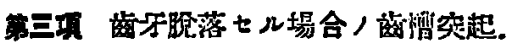

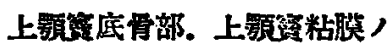

䝷化 $=$ 就 + テ

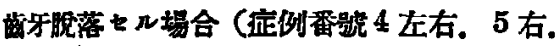
9在右. 10 左. 12 左右. 15 左右. 16 左右. 17 を. 19 左, 22 左. 25 左右. 29 右. 33 右) /齿權

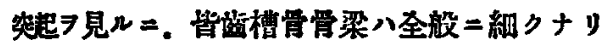

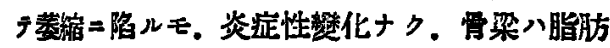

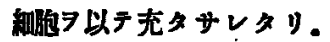

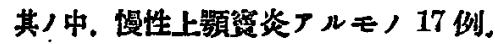

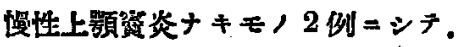
上積䨘底骨部モ大部分八炎症性變化

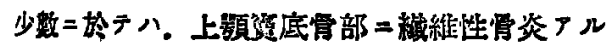
そ) (定倒䧽號。10左。17左, 19 左. 27 右):

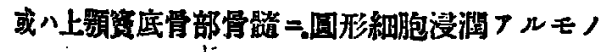

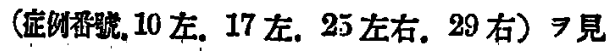

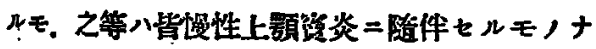

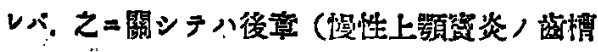
数飠二及ボス變化）＝於テ述プルコト、セり。

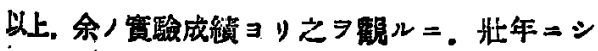

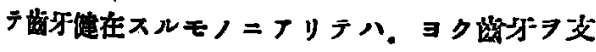

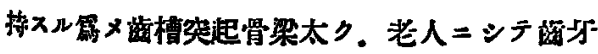

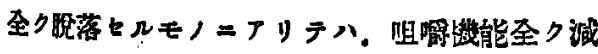

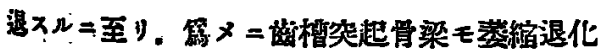

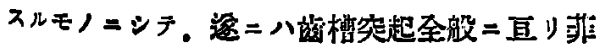

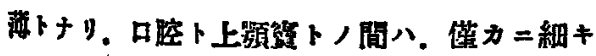

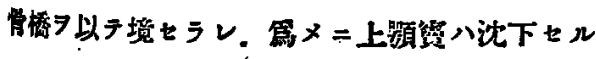
ガ如キ楼 是スルニ至ルモノナり。

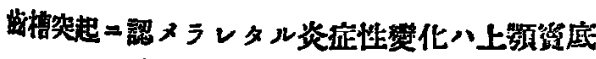

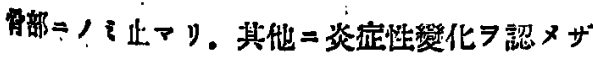

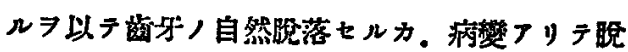
落シ. 病感 治隐シタルモノナリ十不明ナリ。

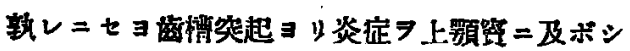
タル形跡ナシ。

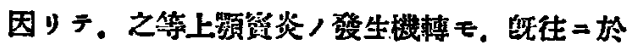
ケル丵性感染习除外セバ。即テ知ラズ知ラズ， 間二感冒等ノ際鼻腔 $コ$ 感染シタル所謂舅地慢 性上䫑琵炎ナリト推察七ラル。

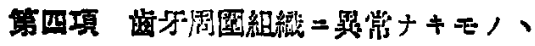

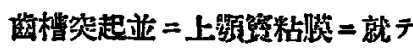

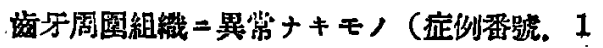

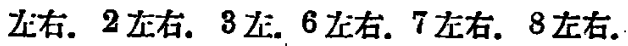
10 右. 11 左右. 13 右. 14 左. 17 右. 20 左右.

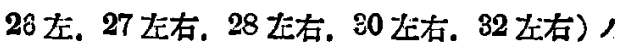

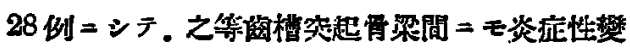

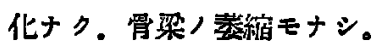

其ノ中.

（1）症例番號 2 左右. 7 右. 10 右. 13 右。 14 左. 17 右. 27 左右. 32 右， 10 例小慢性上 影筧炎厂リ。

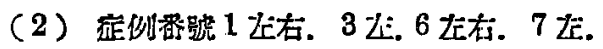
8 石右. 11 在右. 20 在右. 26 左. 28 左右. 20

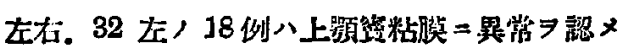
ズ.

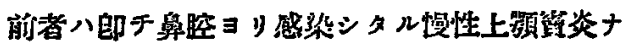
ルコト明膫ナり。

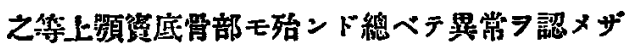

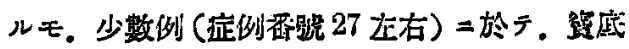

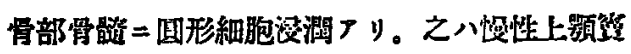

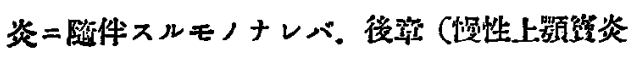

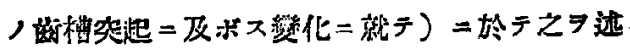
プベシ. 


\section{第五高}

慢性上頻筫焱二於ケル

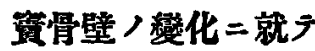

\section{第一项 上靧签粘膜，病理組織學的}

變化 $=$ 就テ

余/检索七ル上影露粘膜，病理組倳像 7 見ル

二. 慢性炎症 7 認ムルモノ多ク 44 例(症例番號 2 左右. 3 右. 4 右. 5 左. 7 右. 9 左右. 10 左右. 12 左右. 13 左右. 14 先右. 15 左右. 16 左右. 17 左右. 18 左右. 19 左右. 21 右. 22 左. 23 左右. 24 左右. 25 左右. 26 右. 27 左右. 29 左右. 31 左右. 32 右. 33 左右） 3 上x.

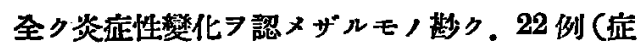
例番號。1左右。3 左。 4 左. 5 右。6 年右. 7 左. 8 左右. 11 左右。 20 左右. 21 左. 22 右. 26 左. 28 左右. 30 左右. 32 左) ナリ。 上碩筫粘獏ノ病理組織學的變化=就テハ. 1892 年. Zuckerkandl /㷋跓 $丁$ 几他. Dmochwski, Wertheim, E. Fränkel, Oppikofer, Hajek ${ }^{\star}$ Uffenorde, Goerke, Manasse, 长川, 宫城, 海 江田，加藤，後梅氏等二因りテ．微二入り細二亘 リ. 研究サレ殆ンド铩ストコロナキガ如ク，玆 二贅言习要セザルトンロナリ。

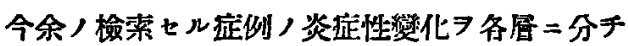
テ䉍單二登明スレバ次ノ如シ。

上皮組織八重展留目圆柱上皮ニシテ。多ク八 著㬚ナキモ盃狀細胞ノ増加スルモノ大部分 メ. 少数=於テ八(症例番號 19 左。22 左. 23 右. 27 左右. 29 左) 多核白血球. 圆形細包， 浸閵フ認メタリ。所タ空胞ノ形成 $フ$ 認メタルモ

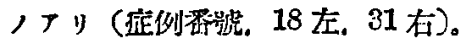

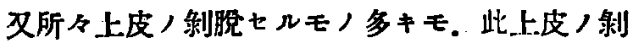

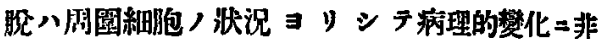

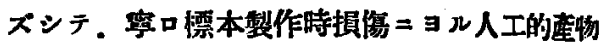
ナリト思考サル。唯極り小数例（症例番號。19

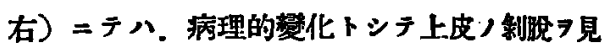
タリ。倘末余，賽驗拝例中二ハ上皮ノ扁平上皮 ニ化生七ルモノハーツモそフ見タルコトナシ。

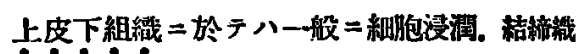

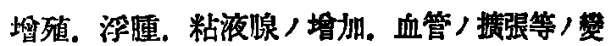
化厂ッ。之等/中細胞浸潤ヨ主トナスニノ，或

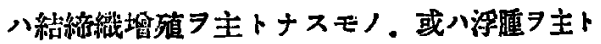
スルモノアリテ、等ノ炎症像八多種多檬二現 ハレタリ。且\%同一組織標本／筧粘膜こテモ部 分的二全ク相異ナル組織像ジスモノナッ。

骨膜ニ八總べテ結隌織ノ增殖フリテ. 其中.

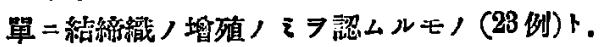
多核白血球。圆形細胞ノ浸潤フルモ/ (21 例) フリ.

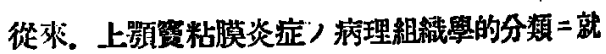
テハ Manasse, Hajek, Nähsmann, 小定並=湤 汇田. Rnnge 等/研究業靕アレドモ。各タ其

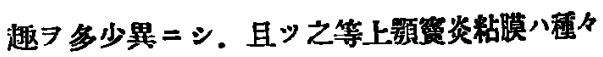
多樣ナル組糡渗 得スト八諸學者ノ稃フル所ニシテ. Oppikofer 八多數，副鼻腔粘膜，組䅧學的检菜 7 行へル モ. えヲ類別スルコトナク．唯各在例二就キ其 病理組緎學的所見 キ=非ラズ。余モ亦單 =之等慢性炎症性焚化 7 記载スルニ止メタリ。

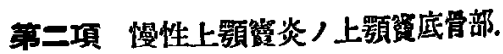

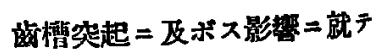
慢性上領瓷炎つルモ（44 例）二於于. 逆二

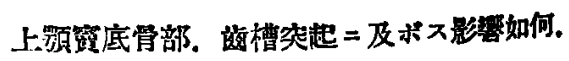
共八中. 症例番號 13 左. 18 右. 19 右. 23 
左右. 26 右. 31 右. 33 左 8 例八. 先=「齿

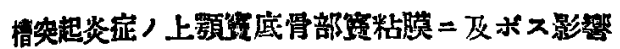
=就テ」/項二於テ进一゙ルガ如ク。慢性上額

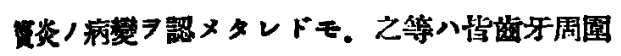

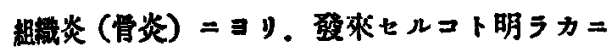
シナ. 炎征八上行性二進行セルモノナレバ. 本 項二於テへ、え习度外視七り。

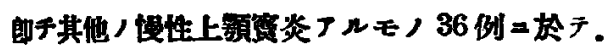

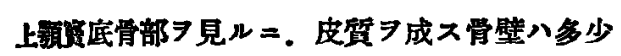

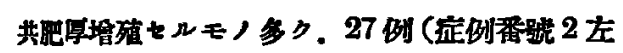
右. 4 右。 5 左。 7 右. 10 左右。12 左右. 14 左右. 15 在右. 16 左右. 17 左右. 19 左右. 21 右. 24 左. 25 左右. 23 左右. 29 左. 32 右. 33 右)シシテ，造骨細胞习莚ダ多数認ムルモノト。 著明ナラズシテ少数えア認ムルモノトフリ。

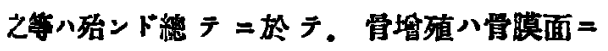

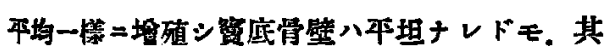

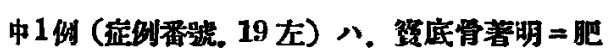

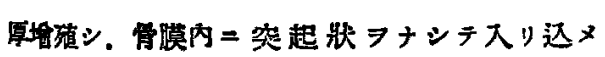
9.

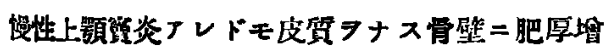

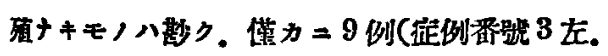
9 左右. 13 右. 18 左. 22 左. 24 右. 29 右. 31 左)

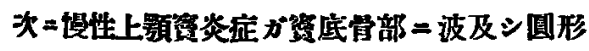

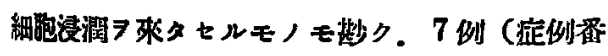
镂10左. 17 左. 25 左右. 27 左右. 29 右) リ.

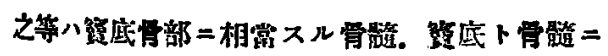

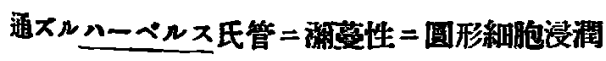
七り。然レドモ之等八管底骨部ニ止マリ，齿槽

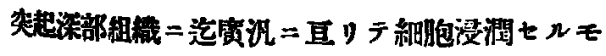
インシ。

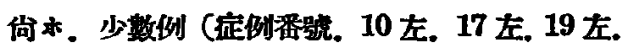

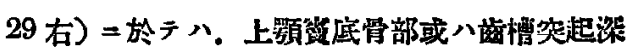

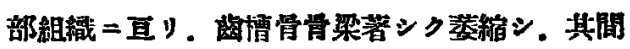

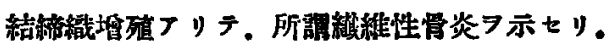

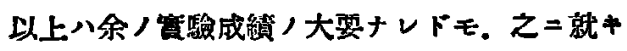

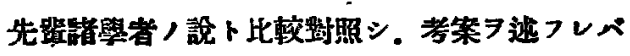
次ノ如シ。

從來.上顆奯炎存在スル場合. 骨組織 $=$ 紮化 7

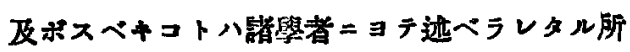
ナレドモ。詳細ナル研究ヨ缺キ之二對スル檢苶 八上影零粘膜，病理二比スレバ．閉却視サレタ ル感ナ+ =非ズ。

Dmochowski 八慢性上顠签炎 18 定例二就キ

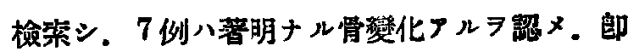
千骨全壁二亘り平均七几骨，盵厚习認义。1 例 ，如キハ $1.5 \mathrm{~cm}=$ 達スルテ見タリト。或ハ小官 板ガ粘膜深部骨膜展二介在シ，或八骨壁卜游政 シ。或八微細＝連絡スルアリテ所謂葉狀骨フ見 タリト云七. Berberich 亦之二左榩七り。

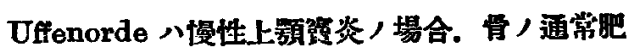
厚释窑化 Verdiohtungs-und Verdickungeprozesse 7 認 メ. 附加理象A Appositionsrorgänge 7 主㣲セり。

Manasse(1922) 八此埸合. 骨/肥厘7見ズン テ、却ッテ笡，美綰ヨ見ルモノナリ。然レドモ

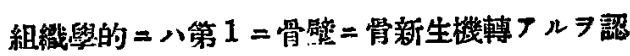

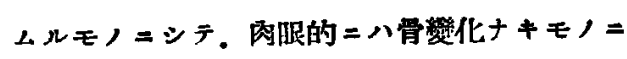

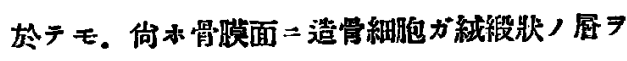

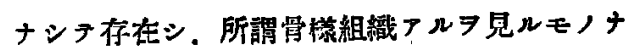
リト述ベ。佾ホ骨新生ハ必スシモ骨壁/厚サマ

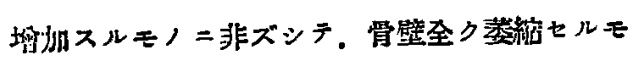

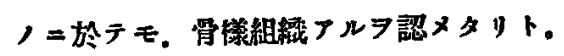

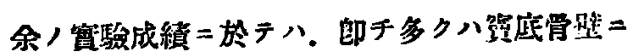




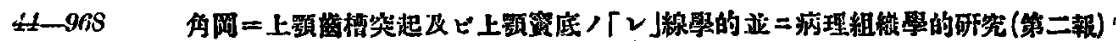

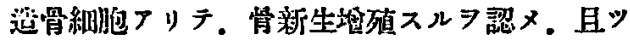
肥厚スルラ認メタルモ. Manasse 云へルガ如 ク骨ノ萎街シ昌タルコトナシ。

Dmochowski, Berberich ノ秘へタル所掼葉政

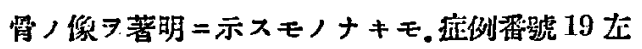

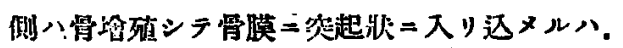
萻朋ナル骨嵝殖フ示スモノナリ。 印于 Berberich, Dmoohowski, Uflenorde , 肥厚說二筧意习表スルモノナレドモ. Manasse

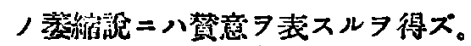

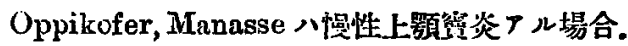

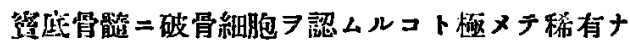
リト逮ベタリ。

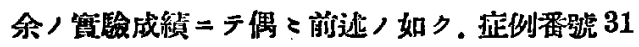

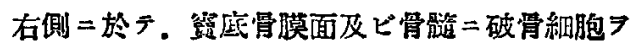

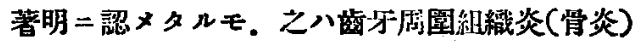

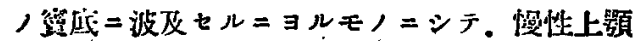
筑炎二由來スルモノラ兒ズ。

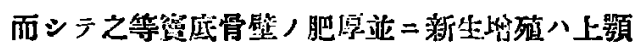
签粘膜二炎症性變化ナキモノ二於テハ,一ツモ

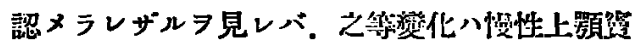
炎二由來スルモノナルコト明ナリ。

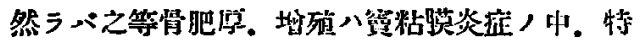
二骨膜，著明ナル资控性變化／有無=ヨリ招隶 セラル、モノナリヤ否ヤノ間题二逢晢スルモ，

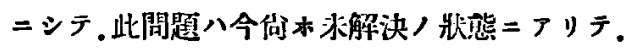

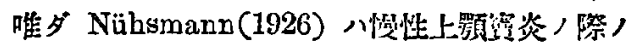

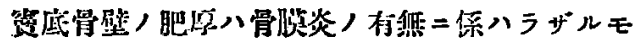

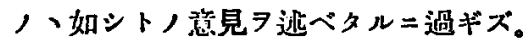

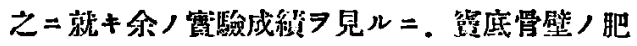

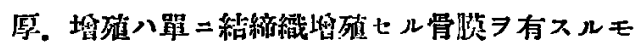
ノ=於テ見ラレ。細胞滀湘著明ナルモノニテ

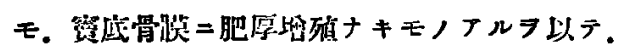

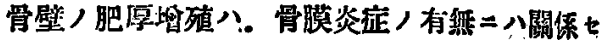
ザルモノニシテ，之八粘獏炎症，箁メ! 二次的

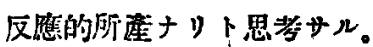

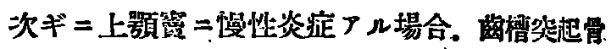

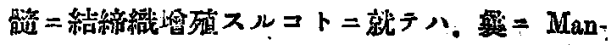
asse(1922), Nühsmann(1926) ガ遮ベタル।: ニテ他ニ詳細ナル記载ラ見ズ。

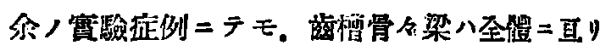

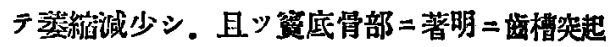

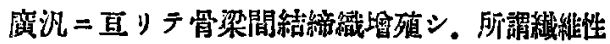
骨炎ノ儌习呈セリ。

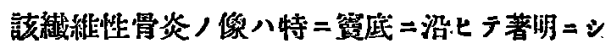

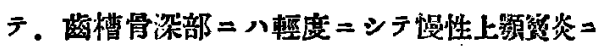
ヨリ二次的二搨來七ルモノト思惟サ几.

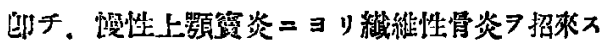
ルモノナルコトラ述プルハ余习以テ满知ナ x.

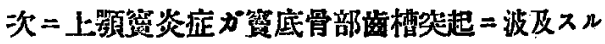
$コ ト=$ 就テモ. 唯 Manasse, Nübsmann $=3$,

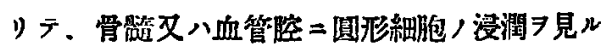
モノナリト逨ベラレタリ。

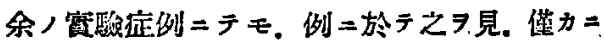

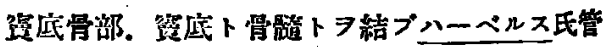

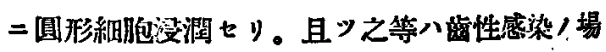

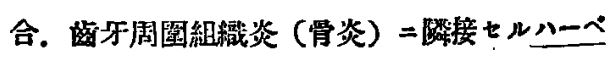
ルス氏管血管二沿ヒテ䈱二波及七ルト其狀態

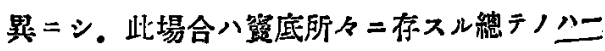

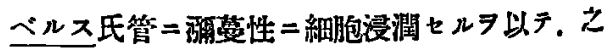

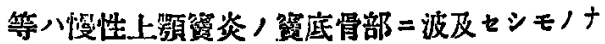
ルコト明ラカニシテ，骨吸收破壊，組践像著明

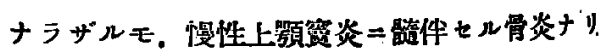
ト云フラ得ベシ。

且ッ。之等細胞浸潤7認ムルモ， 、中. 3 列 


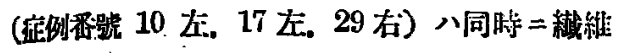

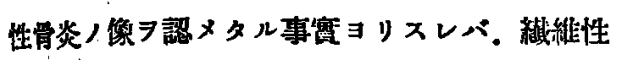
骨炎卜何等カ，因果關係厂ルモ，、如シ。

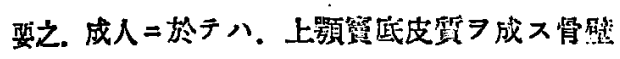

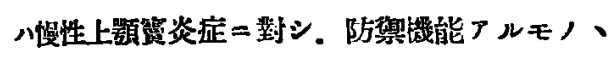

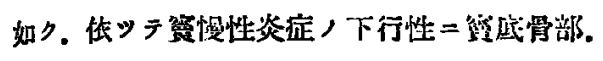
齿槽突起二炎症 ヨ及ボスコト甚ダ断ク，及其程

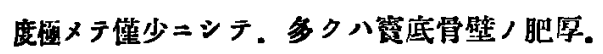

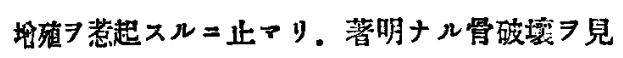
ז.

反之.初生兒及ビ第 2 生䔄期以前ノ小兒ニラハ. 成人卜稍

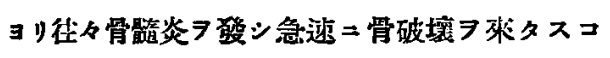

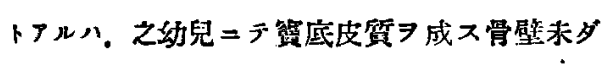

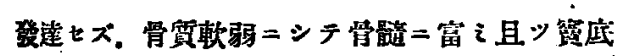
ト学娟トヨ通ズルヘーベルス氏管多たニヨリ。 炎症，下行性波及容易ナルガ篇メナラン。

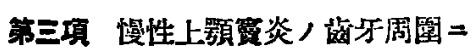
及ボス影㩕二就テ

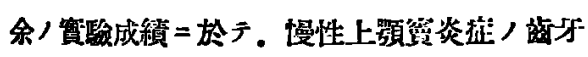

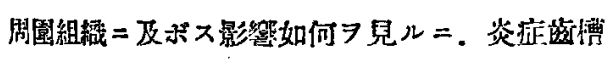

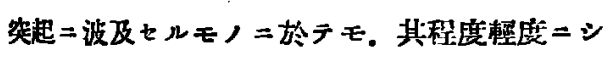

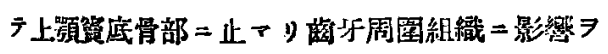
及ボシタル形跡ナシ。

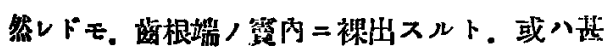

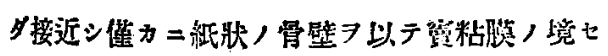

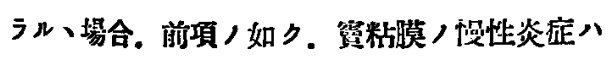

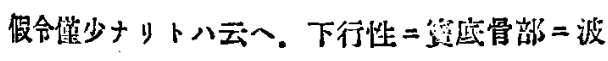
及スルコトアルラ以テ，局所解剖學的应透=

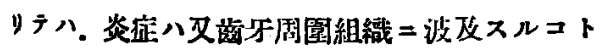
可能ナルベシ。

\section{第 六 整}

「レ」線像卜病理組䄉學的

\section{所見トノ比較}

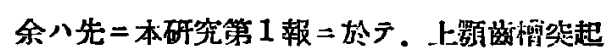

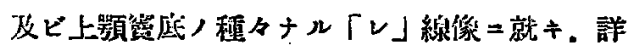
細ニ述ペルトロフリタリ。及其病理組織學的

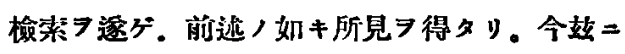

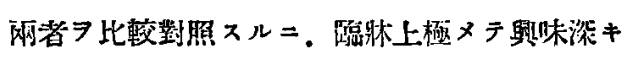
7學工。

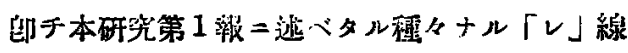
像八病理組織學的二八，如何ナルコトア意味 ルモノナリ+，又如何ナル程度/缜筫性 7 有 ルモノナリヤ. 之八余が本研究习企テタ筑植 ノ目的ニシテ. 以下暂り之二就き論述シ最後=

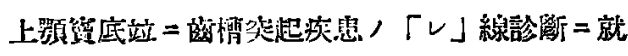
テノ注意ヨ述ベントス。

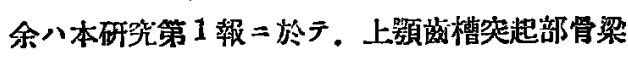
,「レ」線像入，網狀走行 (絞理) 7 示シ。然 モ其较理ハ種タナル像シ以テ表ハレタリ。䬣テ 皎理整然タルモ，或八薄板狀ヨナセルモ， 或八䑤理泥レタルモノ。或八陰影アルモノ。或 八絞理全ク消失上ルモノアリ。今其本態 7 遍求 セントス。

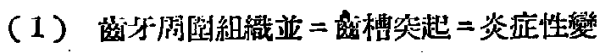

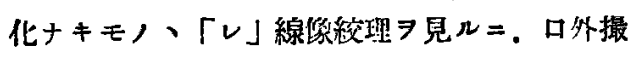
影法ニテハ. 絞理整然タル，23 例习占メ. 㑕

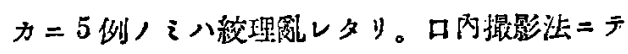
モ。校理整然タルモ，23 侧. 絞理乳レタルモ

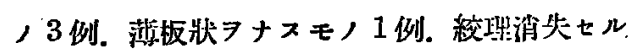
モノ1例ナリ。

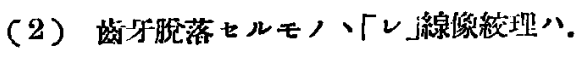

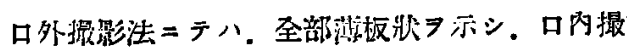




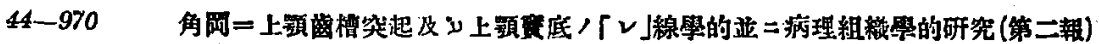

影法ニテ八薄板状 $ヨ$ 示メスモ，12 侧。絞理锦 レタルモ/4侧，㓌影习是スルモ，2例。絞理 整然タルモ，1例ナリ。之等，中，袮維性骨炎

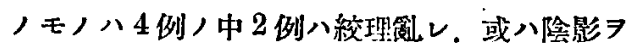
旺セリ。

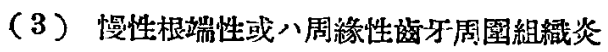
フリテ.夫々慢性根端性骨炎. 或八慢性磁夢性 骨炎アルモノ、「レ」線像絞理八、口外撮影法 =テハ絞理橆レタルモノ 7 例。陰影フルモノ 8 例. 皎理消失セルモ，4例ナリ。

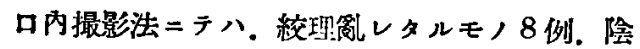
影习呈スルモ，5例。舷理消失七ルモノ4 例. 整然タルモ，2例ナリ。之等慢性骨炎八中. 慢 性确营性骨炎 3 例八中， 2 例八口外，口内撮影 法ニテ絞理消失七り。其他，慢性根端性骨炎八 夫々絞理㼡ル、カ. 陰影テ呈スルカ. 或八消失 シテ表ハレタリ。此中，症例番躆 3 左. 24 左，

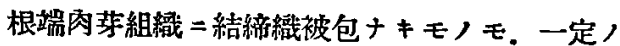

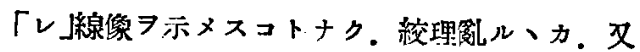
八除影习呈セリ。

慢性根端性蘶牙周圍組織炎，再燃シテ，急性， 轉機 左）八口外撮影法二テ政理除影 $フ$ 呈シ. 且ッ年 輪狀ヨナシテ表ハレタリ。

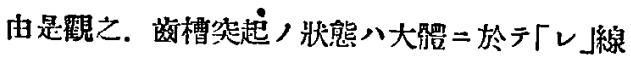

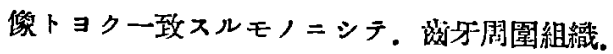
哭槽等起=モ炎症性變化ナキモノ八. 絞理整然

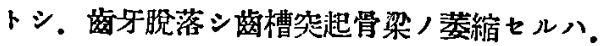

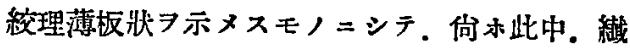
維性骨炎へ口内掫影洗=テハ，䑤理亂し或ハ陰 影习呈スルコトアリ。

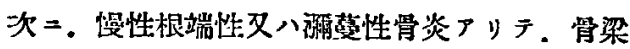
吸收サレタルモノ八，総理得儿、カ，或八㓌影

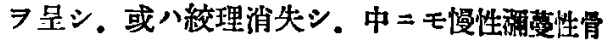
炎八絞理消失シテ表ハル、コト多ク，陶根端肉

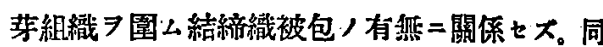
ジ慢性根端性骨炎ニテモ. 如斯. 或ルモノ八较 理亂レ或ルモノ八陰影ヨ呈シ。或几モノ八消失 シテ現ハレタルハ，之放射力向/影響ニョルモ ノト思ハザルでカラズ。

就中.「レ」線像ニテ。特=絞理陰影 7 呈シ或八 较理消失シ病變八周園骨梁卜劃然タル境界フル ガ如ク現ハレタル場合ニテモ。組織像ニテハ.

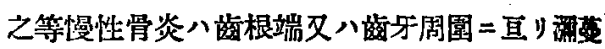
性二薮槽骨二波及シ．細胞浸潤八血管二沿七テ

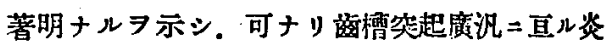
症像フ認メタリ。

由是䫏之，骨梁間血管二沿七テ波及スル骨炎店 像ハ「「レ」線像ニテ現ハレザルモノニシテ。校 理ノ勫々ナル像ヨ示ス八.最モ骨梁ノ吸收サレ。 数嶅トナルコト二起因スルモノナリ。

齿槽宽迟，急性炎症，極っ初期ニテモ、「レ」線

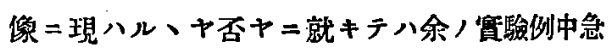
性炎庭ナキヨ以テ，之尹速断スルコト能ハザレ ドモ，少数，例外 $\exists$ 除+慢性骨炎二テ骨梁，吸 收せラレタルモ，、ミが.種タナル變化 7 現八 シタルコトヨリ. Wild Gertrud /論ジタル

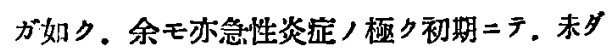
骨二吸收機轉艁キモノニテハ。「レ」線像=モ著 シキ彎化ハ現ハレザルモノナラント思考ス。興 味深キ八，此慢性根端性齿牙周圍組織炎(骨炎) 开燃シテ急性ノ轉機フトリタルモ， 1例（证

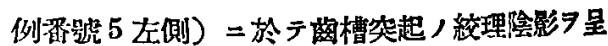

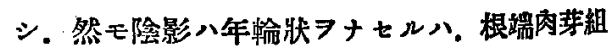

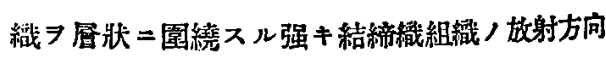
，良キ保件＝惠マ・ルルニヨリ「レ」線影像二 
モ年輪狀ヨナシテ，其危狀ヨ現ハシタルモノナ リ.

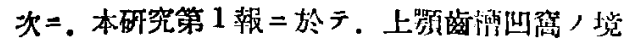
界楾 (底線)八明膫ナル弧將，透明楾フ以テ現 ハレ. 時二細キ透明線 7 . 時 $=太+$ 透朋線 7 . 時ニ太ク䧓園トノ境界不明ナル綵フ以テ現ハル モノナルコトタ述べ．更二其肉眠的所見ヨリシ テ. 其總括的䚓察习行ヒタリ。

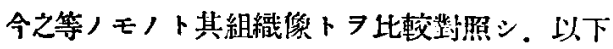
之ョ總括的二述プレベ.

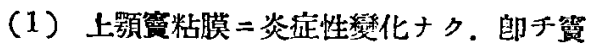
底皮質 7 成ス骨壁，肥厚增殖ナキモノ八，口外 撮影法ニテハ細キ䢪明線 18 例. 太ク凮園卜， 境界不明ナルモ/3 例。太透明 1 線例 $=$ シ テ. 口内撮影法二テハ. 細キ透明線 12 例. 太 周園ト，境界不明ナルモ，8例．太透明 2 . 線例ナリ。

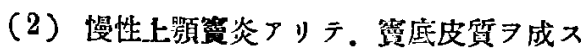

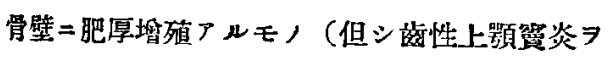
除ク），底楾八、口外撮影法二テハ太ク周園卜 人境界不明ナルモ，20 例。太透明線 4 例。 細キ透明線 3 例ナリ。

口内撮影法ニテへ。太䧓圍卜，覚界不明ナル モ> 12 例. 太透明線 7 例. 細キ透明線 5 例. 不明ナルェノ 3 例ナリ。

（3）慢性上桮管炎フレドモ，琴底皮質习成 又骨壁二肥厚增殖ナキモ，八，叭撮影法二テ 八細+透明線 6 例. 太透朋線 2 例。太力周園 卜筧界不明ナルモ１例ナリ。呐振影法二 テ八細キ透明楾 5 例。太透明線 3 例。太同 圍卜境界不明ナルモノ1例ナリ。

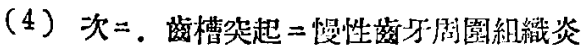

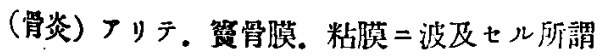

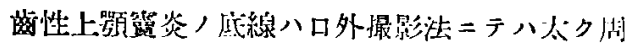

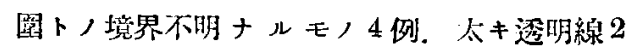

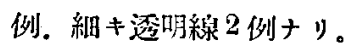

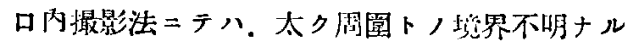
モ，4例. 太去透明線 1 例. 緗透时楾 3 例 $=$ シテ．太ク闧ト，壋界不明ナルモノ多シ。 由是覞之. 霰底線八一䉝的ノモノニ八非ラザル モ，底線，細キ透朋線トシテ現ハル、八，上顎 筧二炎症性變化+キ場合多ク。太难朋線，又 八太ク咸圈卜，境界不明二見八ル、八. 慢性上

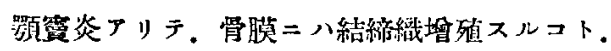

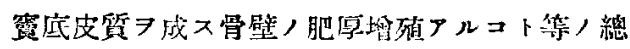
能的／變化二起因スルモノナリ。此中. 慢性上

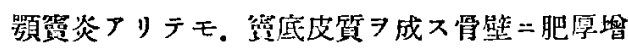
殖ナキモノ八. 細キ透明線ヨ示スコト多キニヨ リ。繁底骨壁，肥厚八底線，太ク閐圍卜，境界 不鹏二現ハルコトニ数シ大ナル役割ヨナスモ， ノ如ク思惟七ラル。

份木，之等，底線八 1 乃至數方所二於厅断裂 ルコトフリテ。余八本研究第 1 報二於テ。底線 ノ断裂卜梅七り。

注目スベキ八。此底線，断裂八䈍底骨檠，吸收

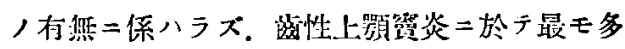
ク見ラレ，8例，中，7例八口外．口内撮影法 二於テ。或八其孰レカー方二於テ之ア示セリ。

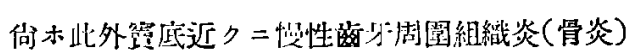
アレドモ。䇺粘膜二達セザルモ，或八之等㾈

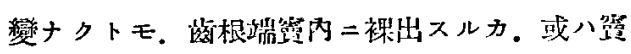

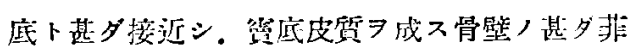
薄ナルモノ八、口外，几内摄影法=テ斷裂习示

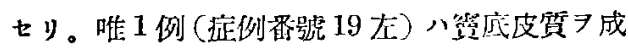

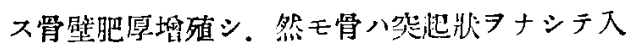
リ込メルモノ二於テ。之ヨ思タ几ハを撮影方向 
＝因ルモノト思惟サル。

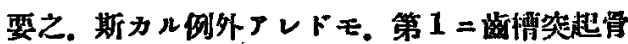

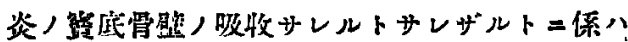

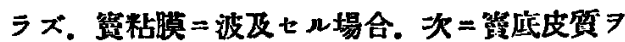

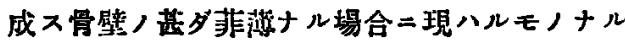
コトラ確メ得タリ。

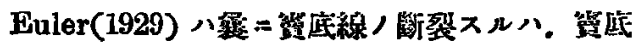

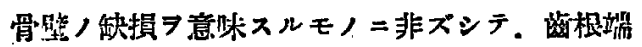

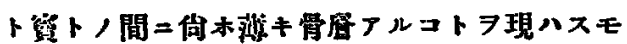

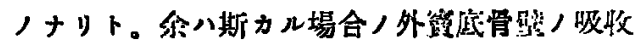

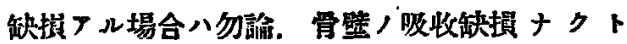

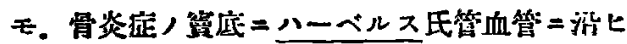
テ波及連緦スルモノ二於テ之マ示スモノナルコ トラ磪メタり。

以上，路底線つ細キ透明緗トシテ現ハレ，且\%

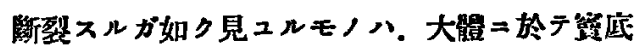
皮質ヨ成ス骨壁ノ極メテ菲蔽ナルコトラ现ハス

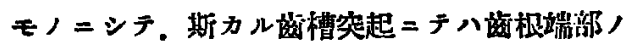

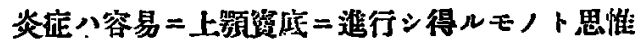

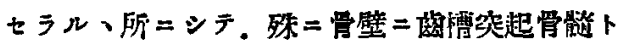
䈍底トヨ結ブハーペルス氏管=富メル場合特= 然り。

次二独底線/太クシテ。厤園ト，境界不明ナル

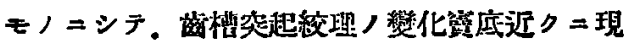

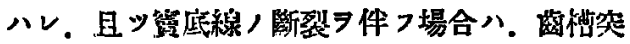

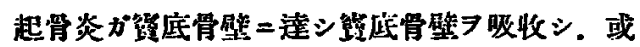

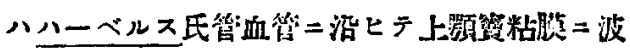

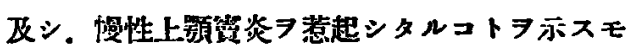

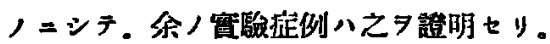

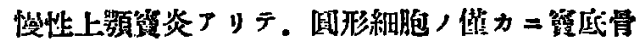

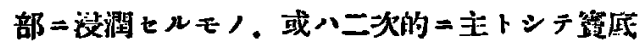

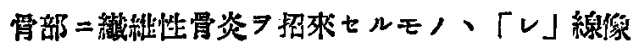

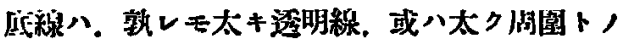

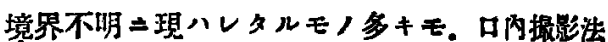

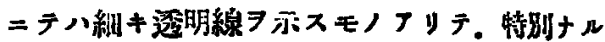

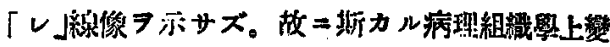
化フルモノト，他ノ單二慢性上影䚋炎フリテ。

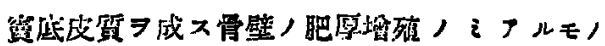

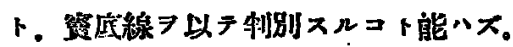

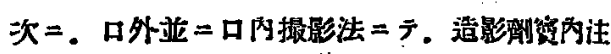

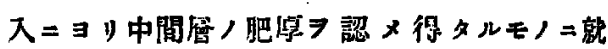

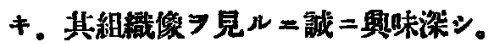

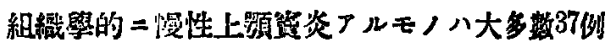

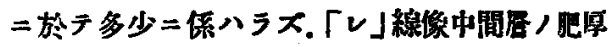

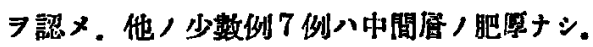

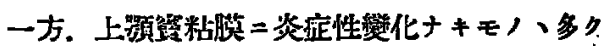

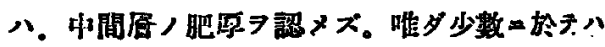
中間愿, 肥原厂りタり。

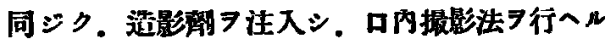

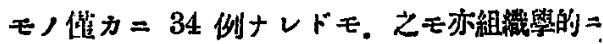

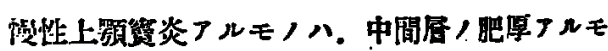
, 16 例。肥厚ナキモノ 3 例. 不明ナルモノ 3 侧ナリ。

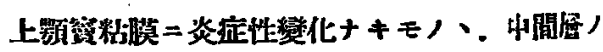

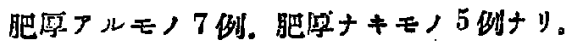

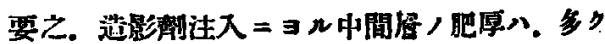

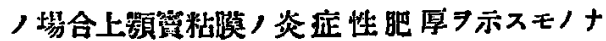
リ。然レドモ特=ロ内撮影法二於テ．多ク，見 レタル粘膜 $=$ 炎症性變化ナキモノ二就テモ。 中

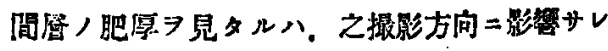
タ緹果ナラン。

践後二．口内撮影法二ヨル齿根膜線「レ」線像

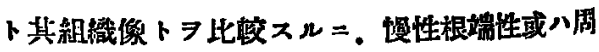

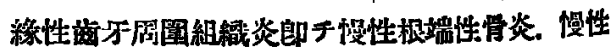

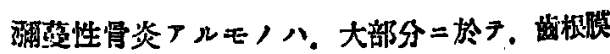
線剭裂七り。 


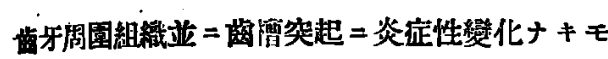

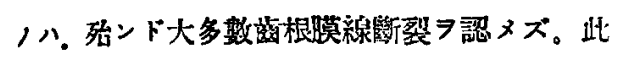
中. 少嘍例 (佂例䧽號 11 左右. 28 右) =於テ.

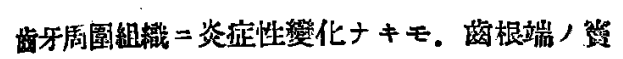
底卜甚多接近シ，嚄カ二薄+䋐維性トナレル骨 壁习以テ筧粘膜卜境セラレ。或川管内二裸出シ。

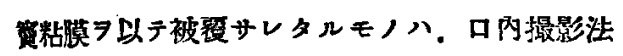
校理整然タル係ハラス离根膜線斷裂七り。同

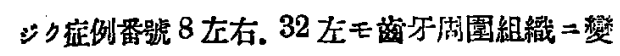

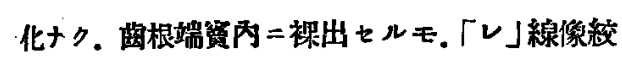

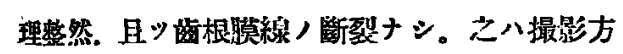
向二因ルモ，ト思惟ス。

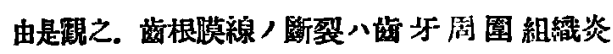
（骨炎）二因ルカ。或八炎症性變化ナクトモ.

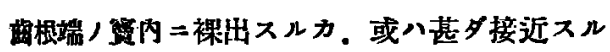

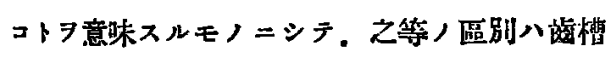

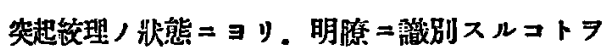
得ペシ。

\section{第七草}

\section{口外撮影法ト口内撮影法}

\section{卜ノ比較}

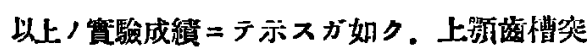

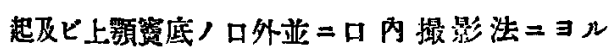
「レ」悢所見八，大顝二於テ相似タレドモ。佾 小雨者习比较七バ稍 2 其所見 7 異ニン各々其特

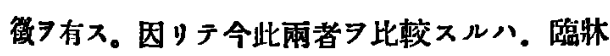
上甚多有意棌+リト信ズ。

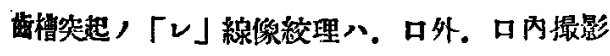
法卜モ其病理組織你卜一致シ。特二絞理整然 ルモ)、薄板狀习ナスモノ八ヨク其組践像トー 致スルモノナレドモ。䟨對的ノモノ＝非ズシ テ.時ニ一致セザルコトラ炛レス。
折カル「レ」線像校理卜組維像卜ノ不一政八。

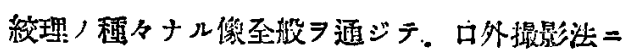
於ヶルヨリ。内内撮影法二於テ多シ。例之. 症

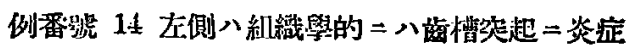
性變化ナク．口外撮影法ニテ八統理整然タル モ。、內掫影法ニテハ絞理消失シテ現ハレタル ガ如シ。但シ纎維性骨炎フルモノ， 口外撮影法 ニテハ皆絞理薄板狀ナレドモ。、内撮影法ニテ

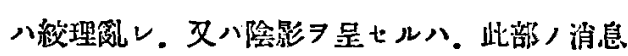
ヨョク現ハスモノト云フべシ。 1929 年 Euler

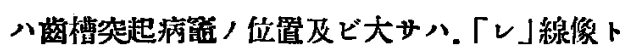

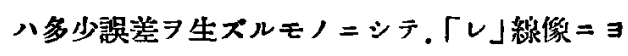
ル誤謬ハ口外撮影法二於ヶルョリ，四撮影法

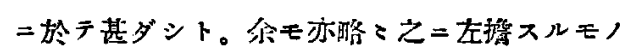

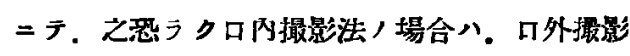
法人場合二比シ，撮影方向＝影笠サル、コト多 キニヨルナルベシ。

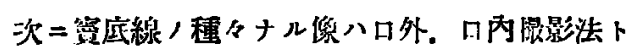

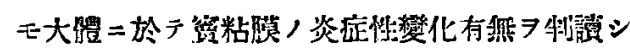
待ルモナレドモ。等ハ決シテ。一義的〉

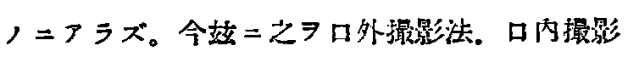
法トア比較スレパ. 口内撮影法ニテハ.上頕算 粘膜二炎症性變化ナキモノ＝於テモ。筑底線，

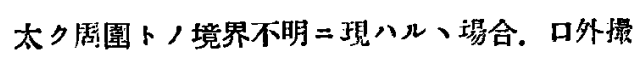
影法ヨリ多シ。

そモ亦. 口內掫影法ニテハ. 口外搌影法二比シ 其撮影方向二影響サル、コト大ナルニ因ルモ， ナリト思惟サル。

1933 年 Isaak Robinsohn ，上頙筧底/消息

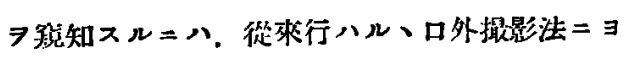
ル外. 口內撮影法フ行フコトフ推獎シ。病的ナ

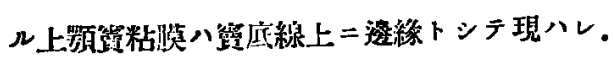

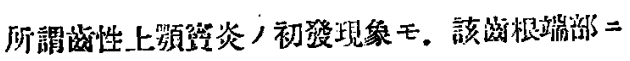




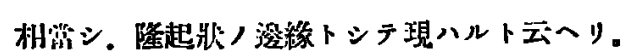

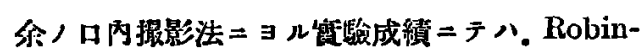

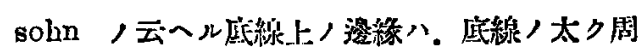
圍トノ境界不明ナルモノトシテ現ハレ。 之八前 逝ノ如ク没シテー事的ノモノニ非ザルコトラ確 メタッ。

Robinsolnn ハロ內撮影法ニテハ、病的ナル上

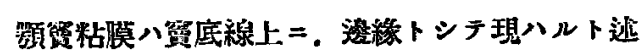
ペタル後. 份ホ底線が年輪牁タナジテ現ハルコ トアリテ，之八反復程患七シ上影筧炎，回數及 ビ炎症ノ强サヨ現ハスモノナリト述べタリ。

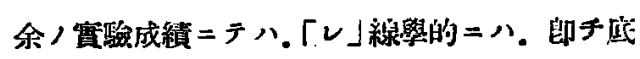
線ハ太ク風圍卜ノ境界不明二現ハレタルモノ レドモ。明㮩二年输狀ヨホスモノナク．且ツ病 理組織學的二モ斯カル所見 ザリキ。病的上顎䆬粘膜 ヨ口内撮影法二テ. 篮 底缐上透線トシテ。現ハスコト二就キテハ、今 後, 研究二侯ッ所厂ラントス。

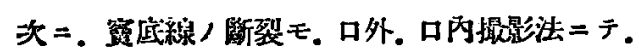

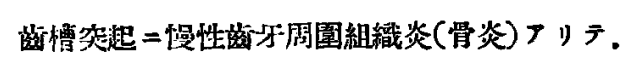

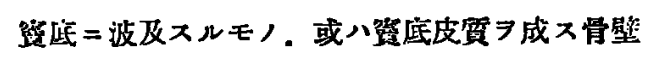
八菲薄ナル埸合二現八ル、點。兩者トモ大同小 異ナレドモ。此中. 口外撮影法二テハ斷裂习示 サ、ルモノト踓モ. 口内撮影法ニテハえヲ示ス モノ稍く多ク．此點口內撮影法ハョク此部八消 砸现ハスモノナリ。

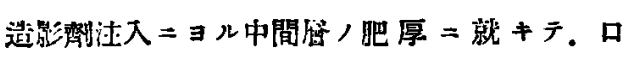

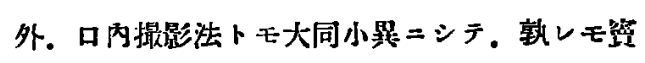
粘膜,炎定性肥厚，有热习現ハスモノナリ。然

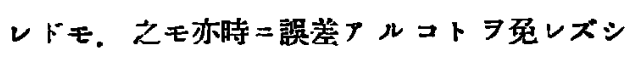
テ. 特二口内撮影法二於テ八路粘膜二炎症性彎 化ナキモノニ於テモ。非間居，肥厚习見タルモ ， 口外撮影法=比シ。其数多キ7胃タル八。

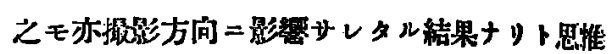
ᄌ。

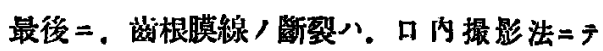

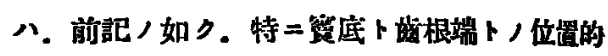

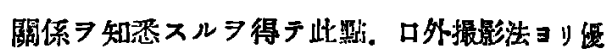
ᄂy.

以上/如乡. 口外並 $=$ 口内撮题法 $=\Xi ル 「 レ 」$

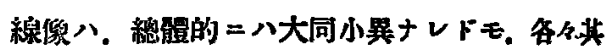
特微フリテ長所短所フリテ， 几内撮影法八齿牙

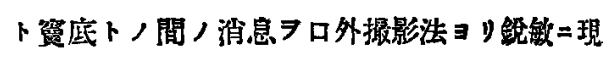

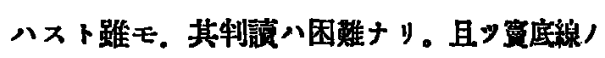
断裂二於ケルガ如ク．口外撮影法二ハ現ハレザ ルモ，モ。田内撮影法ニテハ現ハルコトフルョ

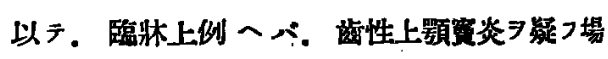
合. 口外撮影法, $i=ヨ$ ス. 口内撮影法习

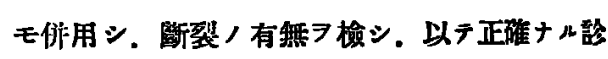

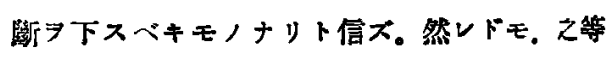
$\lceil レ 」$ 線像八畢竟. 此部位二於ケ几病變习決定 スルニ重要ナル根㨜

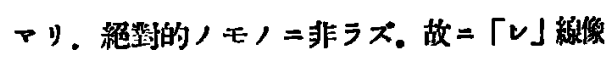

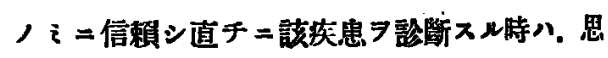

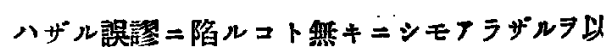

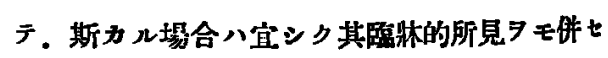
考蔵セザルべカラズ。

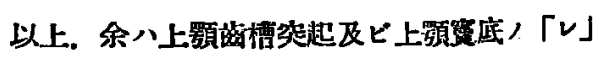
線像ト其組䄉鼬ト 7 比較對照シタル結果。「レ。

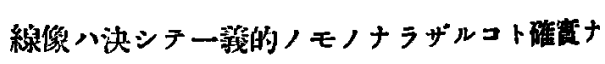

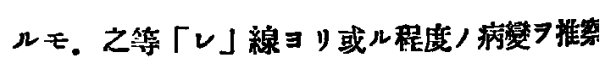
シ.之等相互八關係二就キ。究明シ得タルワD テ.瀶林上得ル所尠カラザルラ信スルモノナ y. 


\section{第入市}

結

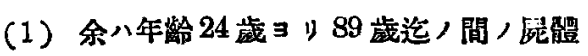

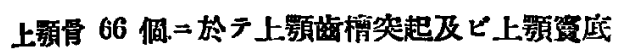

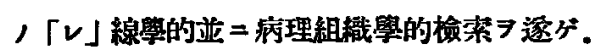
其所見 7 比整晕照七リ。

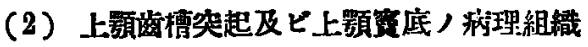
祭的检索八次ノ如シ。

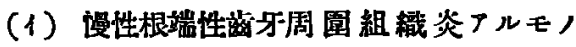

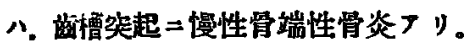
慢性周綵性然牙周圍組織炎厂ルモノ八. 此槽突

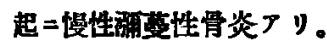

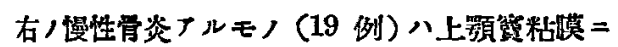

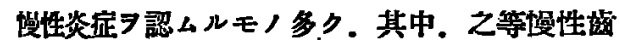

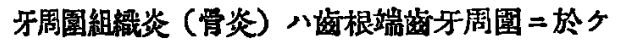

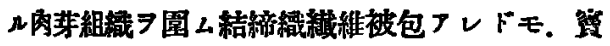

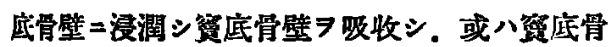
壁ノ吸收セラル、コトナキモ。 ハーベルス氏管

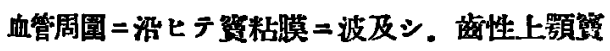
炎习示スモ，8例フリ。此場合，肉芽組䋨 7 囯

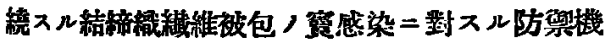
能八釈数的ノモノニフラス。

（口）啮牙全部脱落セル場合. 悉ク齿槽突起

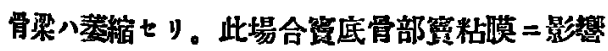
7與へス。

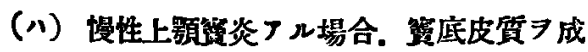
ス骨壁八。肥厚燴殖アルモ，多ク，肥厚增殖㷛

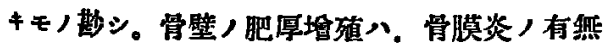
ニ係ハラズえヲ認ム。

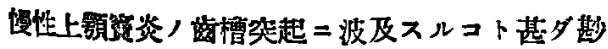

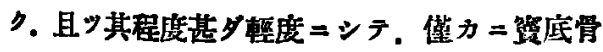

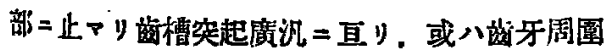

組樴二炎症 マ及ボシタルモノナシ。不少數例二

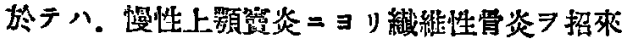
セリ。

（3）病理組織像ト「レ」線像ト 7 比較對照 スルニ次ノ如キ結果＝到達ヶリ。

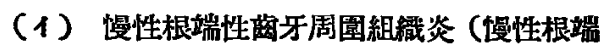
性骨炎). 或八慢性周線性落牙活園組織炎(慢性

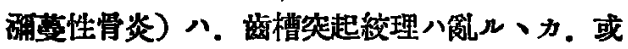
八陰影习是スルカ. 或八絞理全ク消失セり。

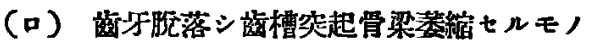
八. 齿槽定起皎理薄板狀习ナセり。

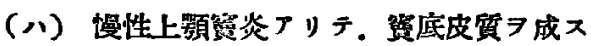

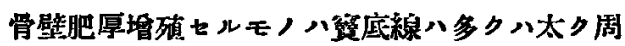
園ト/境界不明ナり。

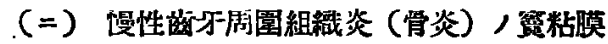
二波及七ルモノ八.多ク八篮底線八太ク周圍卜 ，境界不明二現ハレ，口外．口内撮影法敦レカ

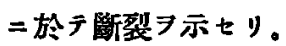

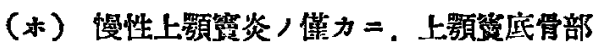
二波及セルモノ，及ビ織維性骨炎八「レ」線像

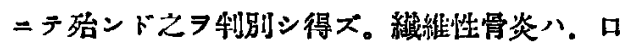

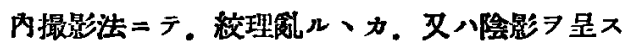
ルコトフリ。

（4） 口外撮影法ト口队撮影法=ヨル「レ」

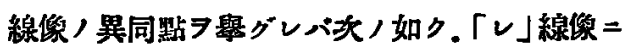
ヨル誤琴八口队撮影法二於テ多シ。即于.

（1）齔槽突起絞理，變化八口外並=口内撮 影法トモ。ヨク其組織像ト一致スレドモ。時二 一致セザルコトアリテ.と川口内撮影法二於テ 多シ。

（口）经应線八口外並 $=$ 口内撮影法=於テ.

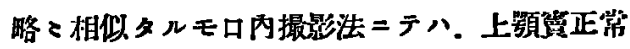
ナルモノニテモ。底線太力風图卜ノ壋界不明二 
現ハル、コト多シ。

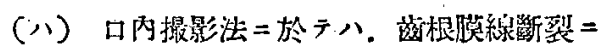

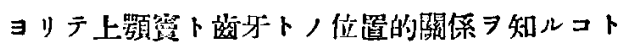

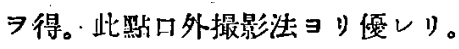

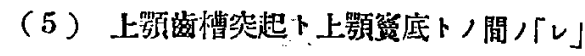
䋩學的檢菜八. 口外撮影法ノ外。口内撮影法7 行ファ可トス。

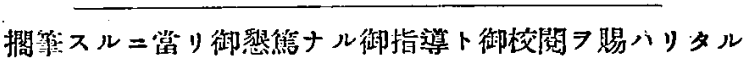

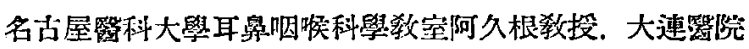
耳鼻咽喉科䅎本醫長二對シ衣心ヨリ感謝ノ意
}

\section{主 雬 文 献}

1) Amersbach, K.: Über die Beziehungen der Oto-Rhino-Laryngologie zur Zahnheilkunde. Dtsch. Mschr. Zahnheilk, 44, 409, (1926). 2) Axhausen, G.: Zur Klassifikation und Behandelung der eitrigen Entzündungen am Kiefer. Dtsch. Mschr. Zahnheilk. 47, 497, (1929'. 3) Berberich, x:- Lehrbuch der Mund-und Rachenkrankheiten, 1932. 4) Blumenfeld und Jafre: Pathologie der Oberluft-und Speisewege, 1931. 5) DenkexKahler: Handbuch der Hals-Nasen-Ohrenheilkunde, Bd. 2, 1926. 6) Dmochowski, z.: Heitrag zur pathologisshen Anatomie und Aetiologie der entzündlichen Processe in Antrum Highmori, Arch. Ohr-usw. Heilk. 3, 255, (1895). 7) Essemann, w.: Uber das Vorkommen von Cholesterin-Krystallen bei Kieferbölenentzündung. Z. Hals-usw. Heilk. 5, 61, (1923). 8) Euer-Meyer: Pathohistologie der Zähne mit besonderer Berücksichtigung der Pathobiologie, der Zähne mit besonderer Berücksichtigung der Pathobiologie, 1927. 9) Fraenkel, E.: Beitrage zur Pathologie und Ätiologic der Nasennebenhöhlenerkrankungen. Virchows Mrshiv. Bd. 143, 42,(1896). 10) Goerke, M.: Ijemerkungen zur pathologischen Anatomie der Nase und ihrer Nebenhöhlen, Arch. Ohr-usw: Heilk. 19, 371, (1909). 11) Hajek, M.: Pathologie und Therapie der entzündlichen Erkrankungen der Nebenhöhlen der Nase, 1909. 12) Hisarsh, In schen-
Pichler: IIandbuch der Zahnheilk. 3, 50̄7. 13) Hoeprel, w.: Uber das .Verbalten der Kieferlöhlenschleimhaut bei Entzündungsprozesse des Paradentiums. Dtšh. Zalın-, Mund-und Kiefer. heilk. Bd. 4, 44, 116, (1937). 14) Immenkamp. A.: Die Bedeutung infizierter Oberkieferzysten für die Pathogenese von Antrumerkrankungen mit einem Beitrag zur Frage der Regeneration des knöshernen Antrumbodens. Dts:h. Zalın-, Mund-unk Kieferheilk. Bd. 2. 419,1935 . 15) Jensen, w.: Beiträge zur Bakteriologie und Histologie der Nasennebenhöhlen. Z. Hals-usw. Ieilk. 32, 439, (1933). 16) Kxumbein, c.: Zur Histopathologie der Kieferhōhlenschleimhaut. Z. Laryng. 14, 178, (1925). 17) Manasse, P.: Die pathologisshe Anatomie der Nebenhöhlen. eiterungen, Z. Hals-usw. Heilk. 4, 473, (1922). 18) Meyer, w.: Der Einfluss der radikalen Kieferhöhlen'speration auf die Vitalitat der benachbarten Zähne. Dtsch. Zahn-, Mund-und Kieferheilk. Bd. 2. 434, (1935). 19) Minder: 50 Selitionsbefunde der Nase und deren Nebenhöhlen unter Berücksichtigung der Gesichtsschädelmasse. Arch. Ohr-usw. Heild. 12, 328, (1902'. 20) Oppikofer, E.: Beitrăge zur normalen und pathologischen Anatomie der-Nase nnd ihrer Nebenhöhlen. Arch. Ohr- usw. Heilk. 19, 28, (1907). 21) Derselbe: Mikroskopische Untersuclung der Schleimbaut von 165 chroni- 
scher eiterunden Nebenhöhlen der Nase nebst Beitrag zur Genese der Plattenepithelcarcinome der Nbenhöhlen. Arsh. Ohr-usw. Heilk, 21, 422, (1909). 22) Range: Die entzïndlichen Erkrankungen der Nase und ihrer Nebenhöhlen in Henke-Labarsch. Handbuch der speziellea path. Anatomie und Histologie. 3. 1 (Berlin 1928). 23) Sehniegelon, E.: Ober akute Osteomyeltis des Oberkiefers. Arch. Obr-usw. Heilk. 5, 115. (1896). 24) siegmnnd, Hns - Die odontogen Ostitis, des Kieferknochens. Beitx. Path. Anat. 83, 289, (1929). 25) Ateimbardt, G.: Die Gefasssversorgung des gesunden, kxanken und zabulosen Kiefers. Disch. Zahn-, Mund-und Kieferheilk. Pd. 2, 265, 329, 1935. 26) Unenorde, W.: Die verschiedene Eatzündungsformen der Nasenhōhlenschleimhant and ihre Behandelung. 2. Ohrenheilk. 72133 und 192 (1915). 27) peraenes Pathologie und Therapie der serösen Nebenhohlentztindung. Z. Laryng. 17, 1, (1928). 28) Wavownks, Tas Chronische eitrige Entzündung der Kieferhöhle im Lichte der Zahlen und der klinischen Beobachtungen in Wilno. Msch, Ohreabeilk. Jg. 67, 153, (1933). 29) Wassmand, II.: Lehrbuch der praktischen Chirurgie des Mundes und des Kiefer. Bd. i, 1985. Bo) Wenlxl, D.: Röntgenologische-anatomische Studien aus dem Gebiete der Kieferpathologie. Vjschr. Zahnheilk. Jg. 37, 1, (1921). 31) Dersellso: Periodotitis oder Osteomyelitis. Zahnarztl. Rdsch. 37, 864, (1928). 32) Whker, F.: Statistische Untersuchungen tiber die Entzündung der Nasennebenhőhlen an Hand von 2000 Sektionsfallen. Z. Jaryng. 25, 404, (1934). 33) zange:
Sinnsitis maxillaris nnd Zxhne. Vortrag auf der Versamml. d. Vereinigung sïdwestdeulscher Hals-, Nasen- und Ohrenärzte in Würzburg am 5. und 6. Mărz. 1932, referiert in Zbl. Oto-Rhino-

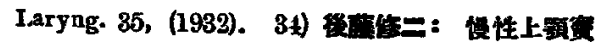

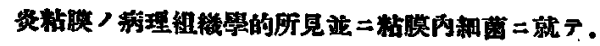
第1，2，3，4編。大日耳第４1复，1619，1641,

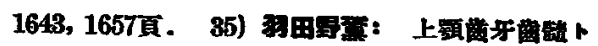

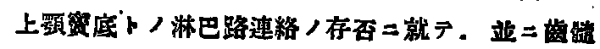

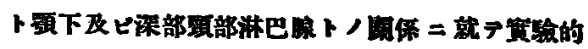
研究、火月耳兵。第42卷，1695直，昭和11年，第 43

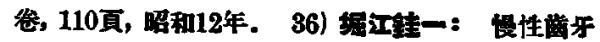

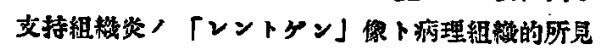

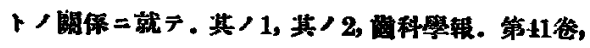

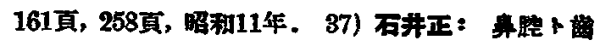

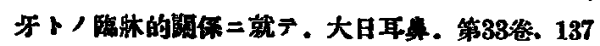

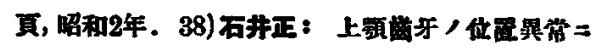

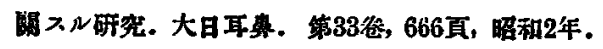

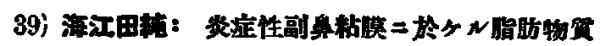

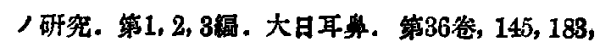

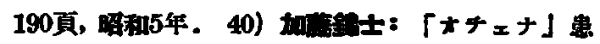

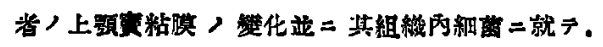

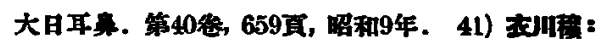

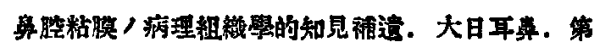

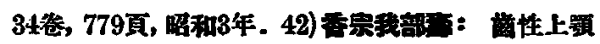

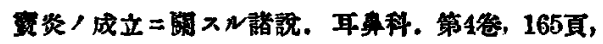

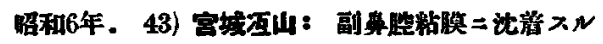

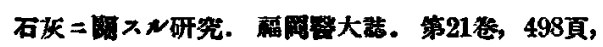

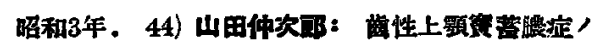

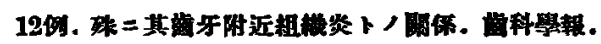

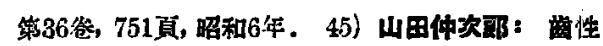

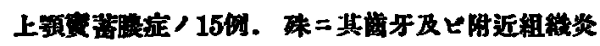

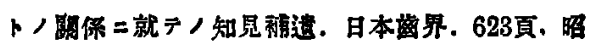
和7年.

\section{附・固 鿁 明}

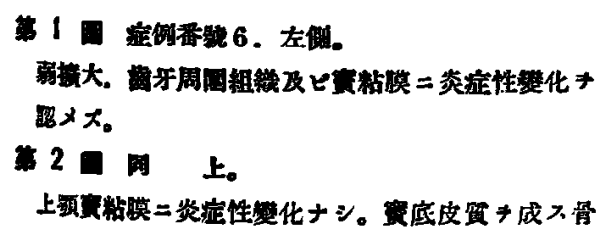

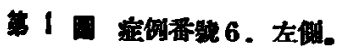

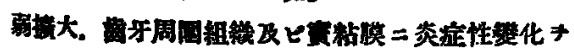
此メ大。

草20网上。

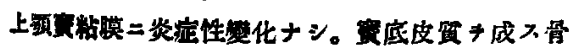

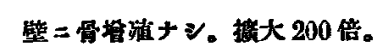

第 3 症例番㩆 9 . 右俔。 弱蜜大。

第 4 同上。

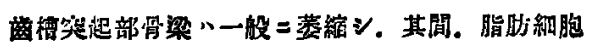




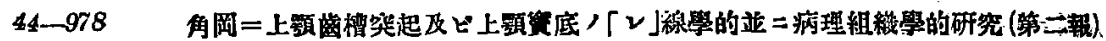

キ以テ充タサル。㨿大 60 倍。

第 5 圆 症例番蹠 19. 右侧。

弱㨜大。

第 6 图同 上。

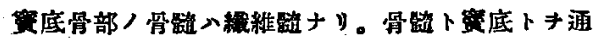

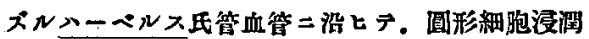

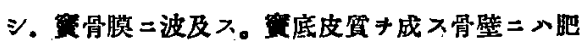

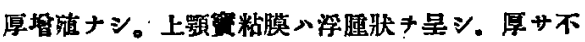

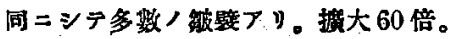

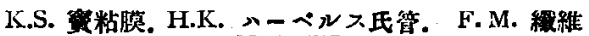
能通。

第 7 圆 症例番號 33. 左側. 弱携大。

第 8 圆同上。

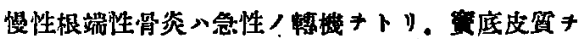
成ス骨壁二達シ，次デ算底二通ズルハーベルス氏

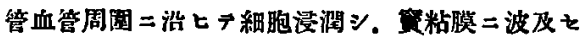
、撰大 45 倍。

R.I. 调形細胞浸洞。

第 9 圆上。

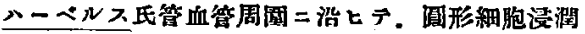

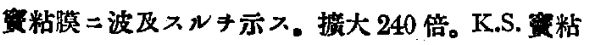
膜. G. 血管. R.I. 调形細胞浸洞。

第 10 图症例番號 31 ，右惻。 弱撗大。

第11国同上。

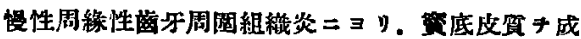

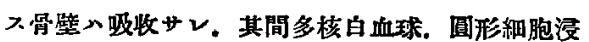
潤シ管粘膜二波及フルキ示入。摭大 60 倍. K.S.

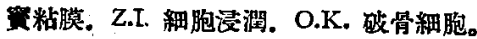

第 12 圆同上。

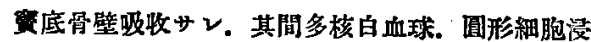

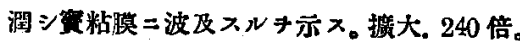

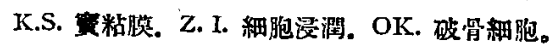

第 13 圆症例潘影 23. 左倒。

弱接大。
第 14 圆：同:

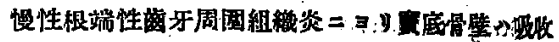

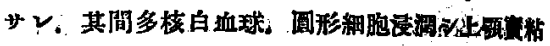

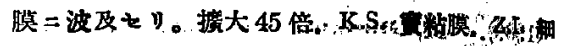
胞设閩。G. 肉茅租織。

第.15圆同：上。

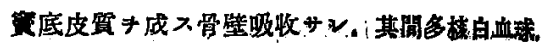

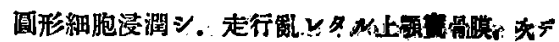

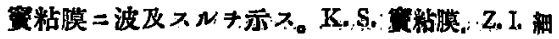

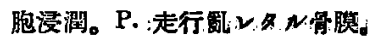

苇 16 圆症例番影 10。左側。

第 17 圆、同上。

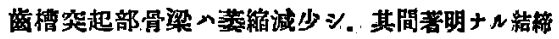

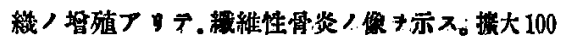

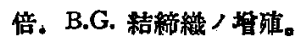

第 18 圆 症例番㩆 25: 右僛。

弱摭大。

第 19 回同上。

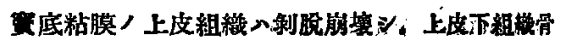

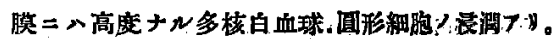

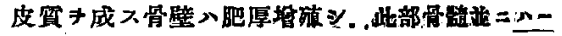

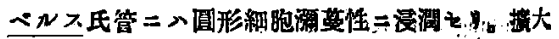

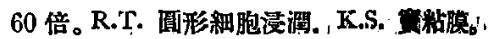

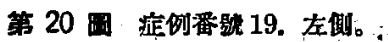
弱摭大。

萧 21 圆同 上。

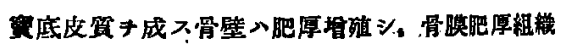

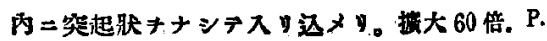
骨膜。

第 22 圆痁例番呺 3. 右側。 弱摭大。

筆 23 固同 上。

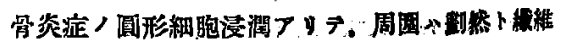

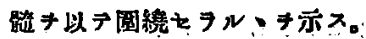

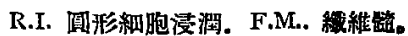




\section{角岡 論 文 附 圖}

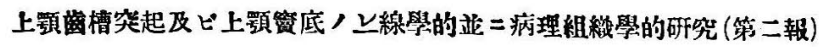

Fig. 1.

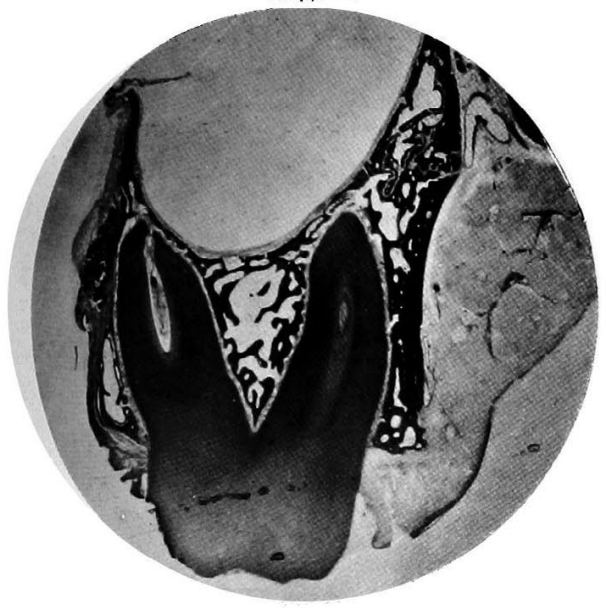

Fig. 3.

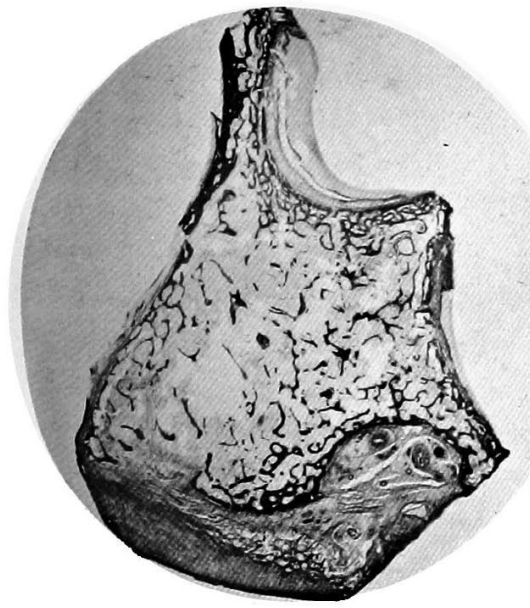

Fig. 5.

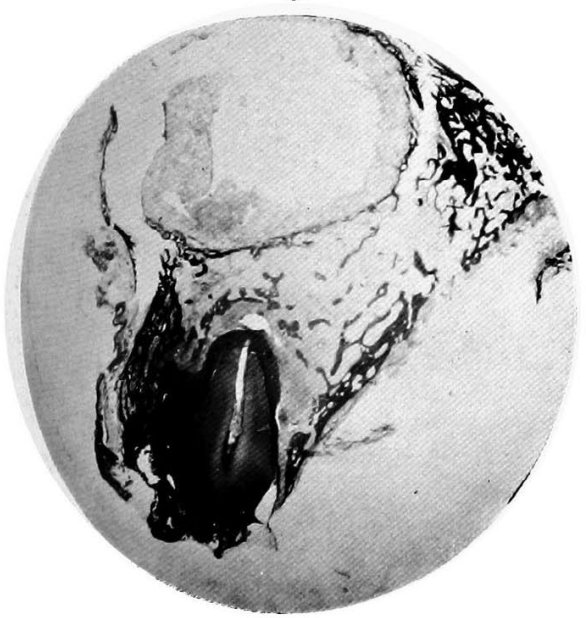

Fig. 2.

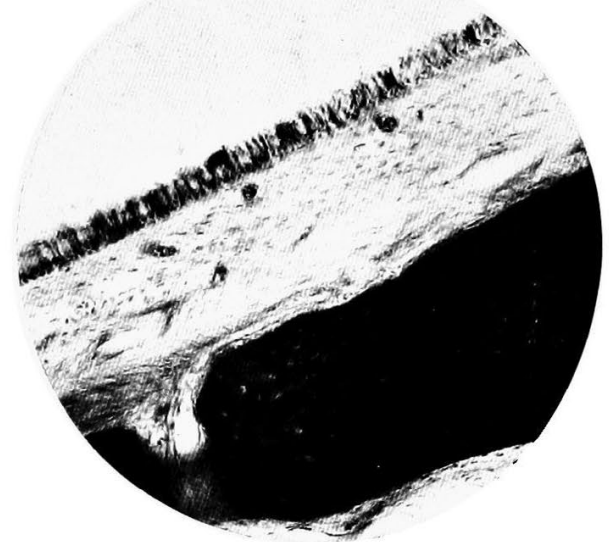

Fig. 4.

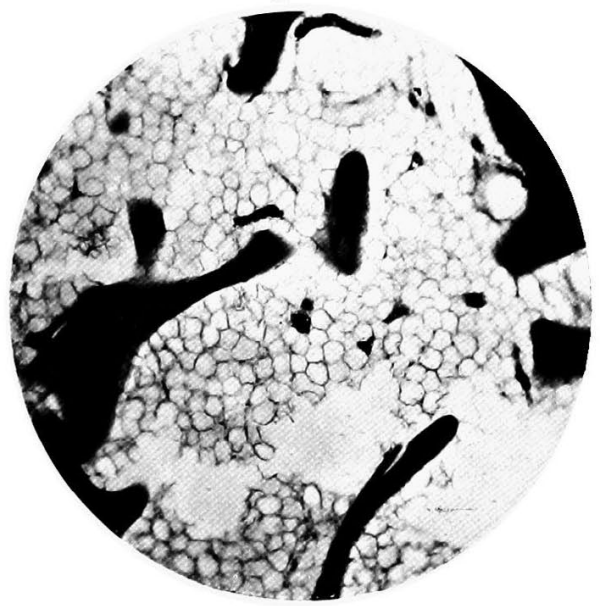

Fig. 6.

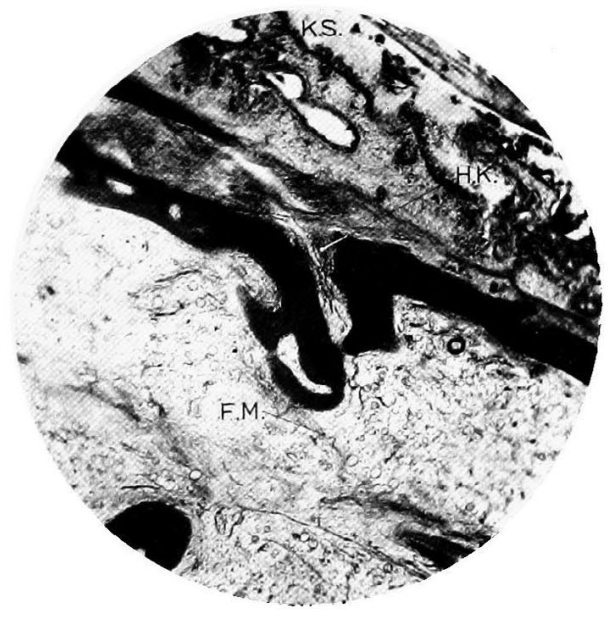

Dr. Saburo Tsınooka: Röntgenologische und patho-histologische Untersuchungen über die Beziehungen $z$ wischen dem Alveolarfortzatz und der Oberkieferhöhle. (II. Mitteilung). 


\section{角岡 論 文 附 圖}

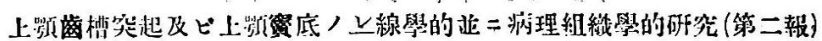

Fig. 7.

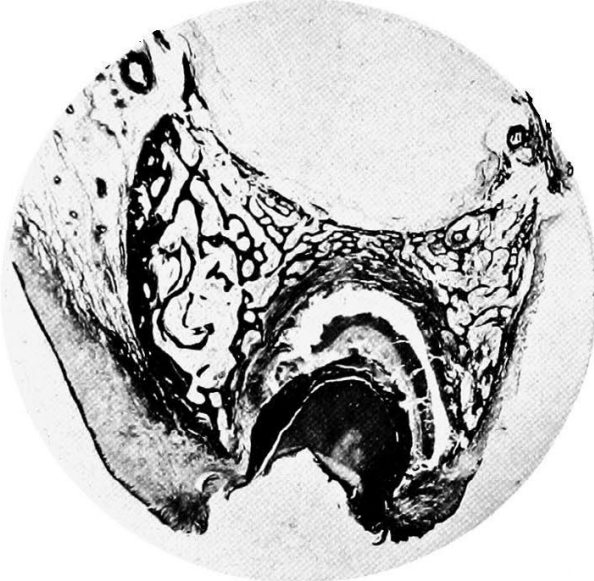

Fig. 9.

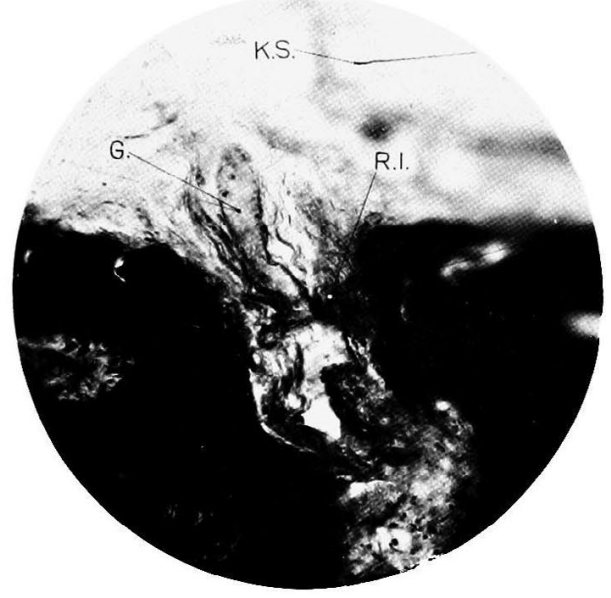

Fig. 11.

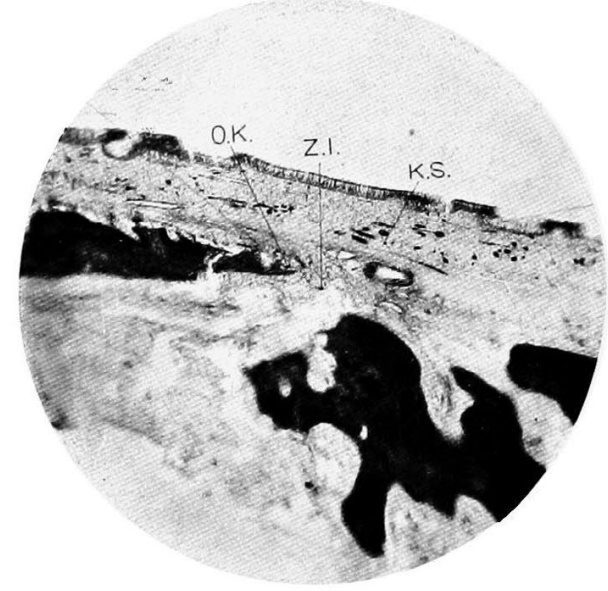

Fig. 8.

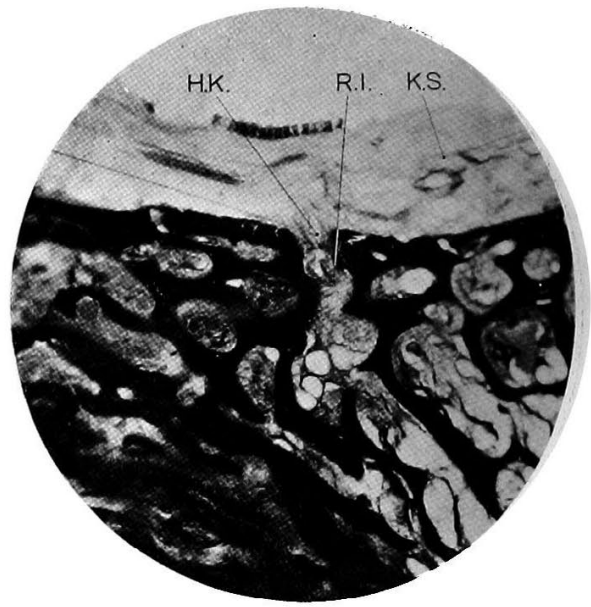

Fig. 10.

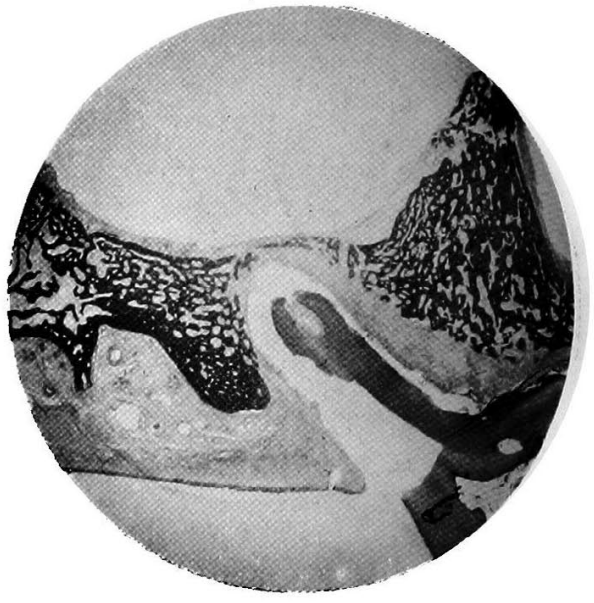

Fin. 12.

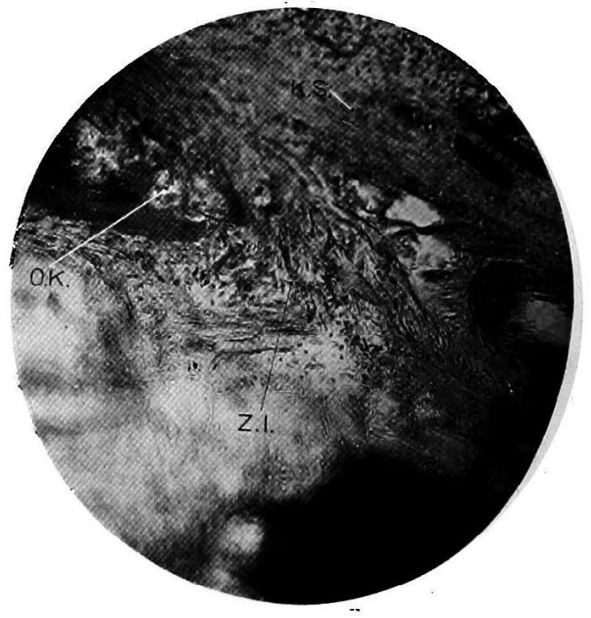

Dr. Saburo Tsunooka: Röntgenologische und pathu-histologische Untersuchungen über die Beziehungen $z$ wischen dem Alveolarfortsatz und der Oberkieferhöhle. (II. Mitteilung). 


\section{角岡論文附圖}

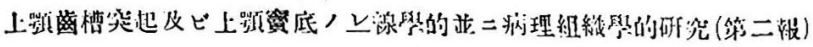

Fig. 13.

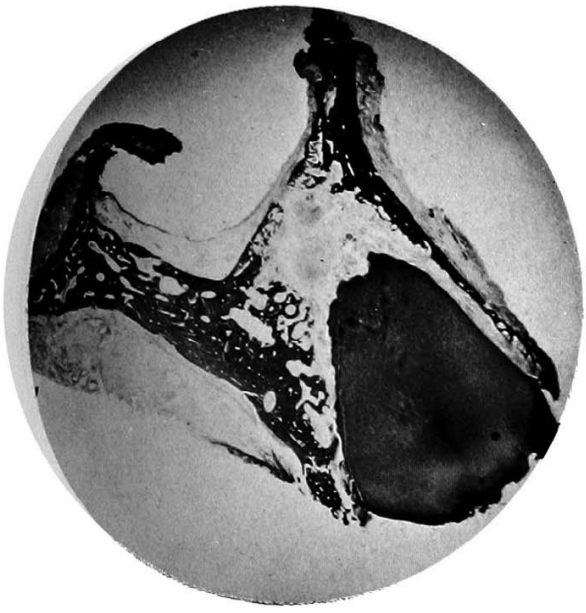

Fig. 15.

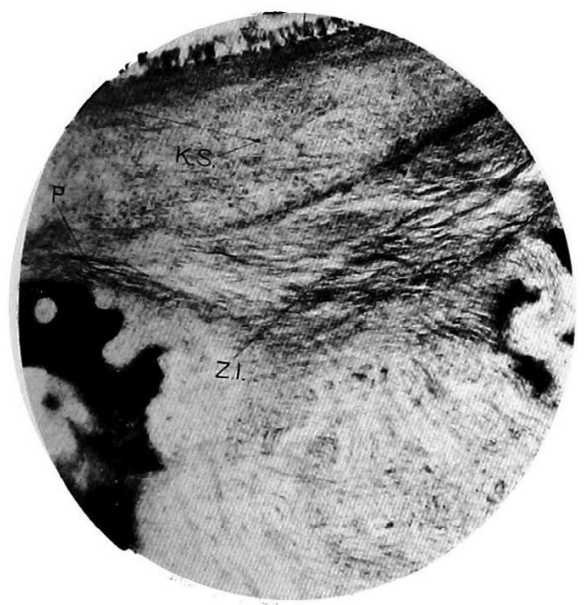

Fig. 17.

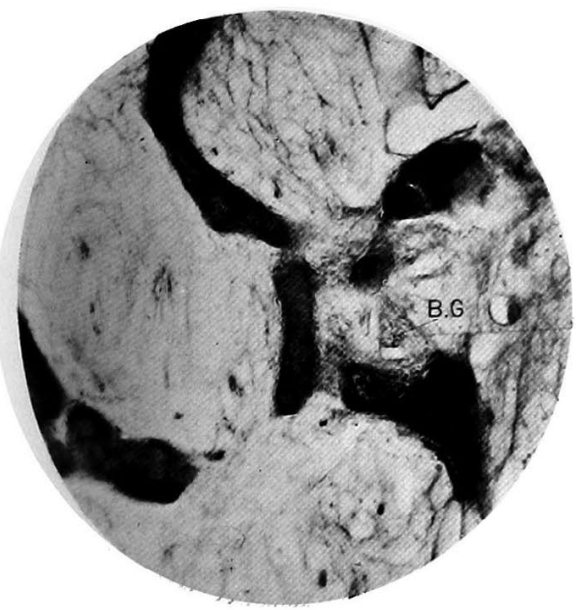

Fig. 14.

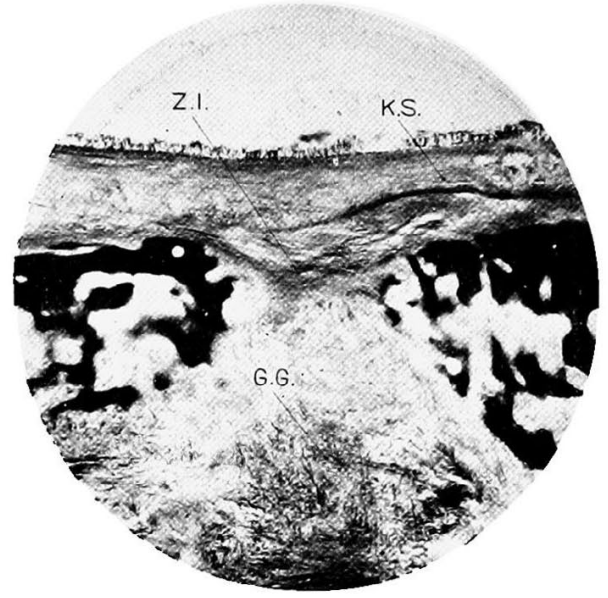

Fig. 16.

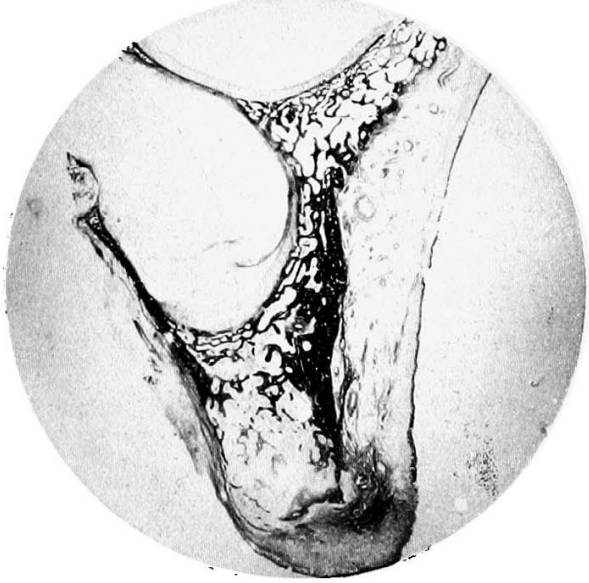

Fig. 18.

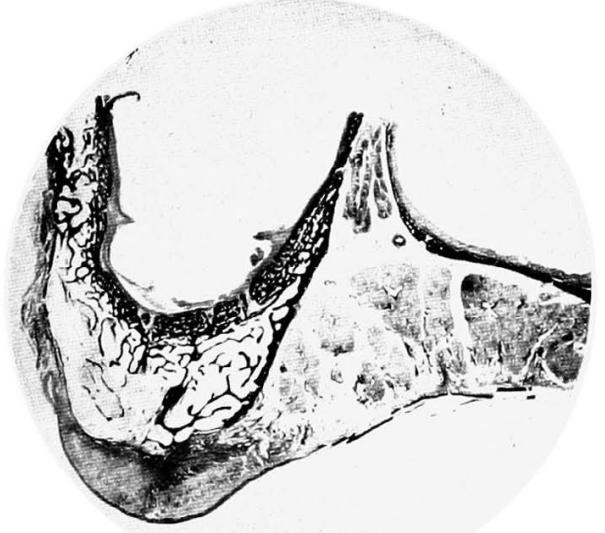

Dr. Saburo Tsunooka: Röntgenologische und patho-histologische Lntersuchungen über die Beziehungen zwischen dem Alveolarfortsatz und der Oberkieferhöhle. (II. Mittcilung). 


\section{角 岡 論 文 附 圆}

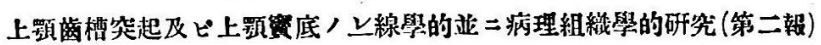

Fig. 19.

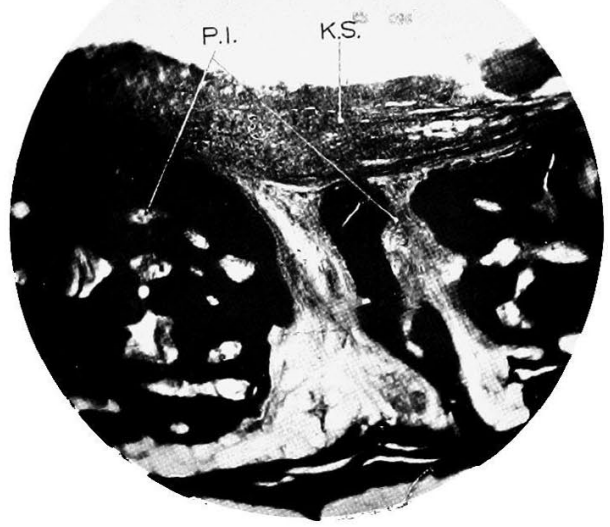

Fig. 20.

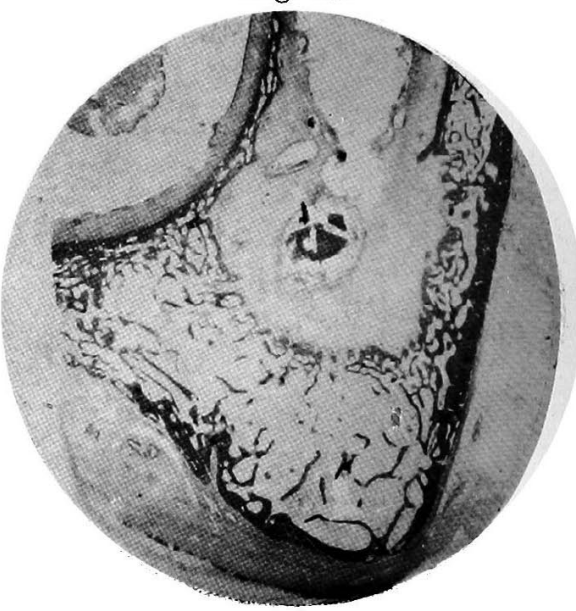

Fig. 21.

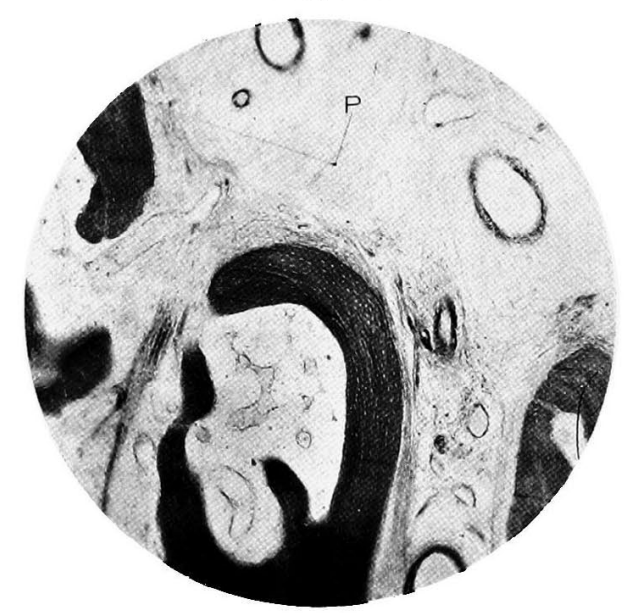

Fig. 22.

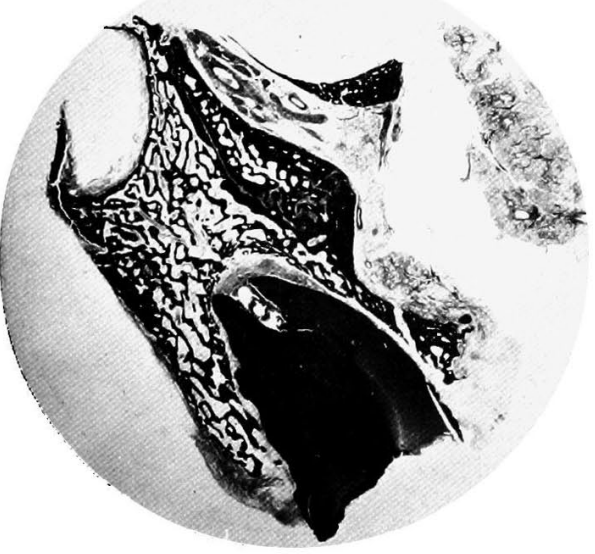

Fig. 23.

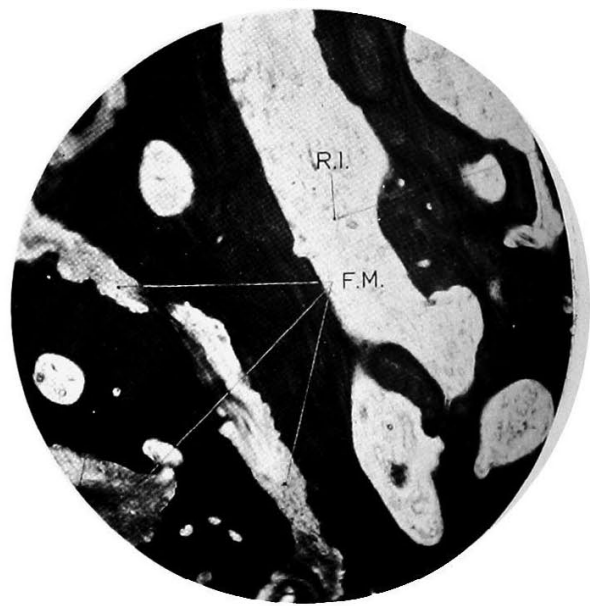

Dr. Saburo Tsunooka: Röntgenologische und patho-histologische Untersuchungen über die Beziehungen zwischen dem Alveolarfortsatz und der Oberkieferhöhle. (II. Mitteilung). 